INSTITUTO DE PESQUISAS ENERGÉTICAS E NUCLEARES Autarquia associada à Universidade de São Paulo

\title{
ESTUDO DA INCORPORAÇÃO E LIBERAÇÃO DE UM EXTRATO DE ALGAS VERMELHAS EM MEMBRANAS DE HIDROGEL
}

\author{
RENATA HAGE AMARAL
}

Dissertação apresentada como parte dos requisitos para obtenção do Grau de Mestre em Ciências na Área de Tecnologia Nuclear - Materiais

Orientador:

Dr. Ademar Benévolo Lugão 
INSTITUTO DE PESQUISAS ENERGÉTICAS E NUCLEARES Autarquia associada à Universidade de São Paulo

\title{
ESTUDO DA INCORPORAÇÃO E LIBERAÇÃO DE UM EXTRATO DE ALGAS VERMELHAS EM MEMBRANAS DE HIDROGEL
}

\author{
RENATA HAGE AMARAL
}

Dissertação apresentada como parte dos requisitos para obtenção do Grau de Mestre em Ciências na Área de Tecnologia Nuclear - Materiais

Orientador:

Dr. Ademar Benévolo Lugão 
Este trabalho é dedicado a todas as pessoas que participaram de sua realização. Aos meus pais, David e Wilma, pelo apoio e paciência. Aos meus queridos amigos, pela força e incentivo que me deram durante este período. 


\section{Agradecimentos}

Ao Dr. Lugão, obrigada pela oportunidade e apoio durante a realização deste projeto.

Á Sizue Ota Rogero, muito obrigada por todo apoio, incentivo e disposição em me ajudar e ensinar nos momentos em que precisei de seus conhecimentos.

Ao Dr. José Roberto Rogero, obrigada pelo importante suporte dado durante a realização desta pesquisa.

Á Dra. Áurea S. Cruz e Rezolina Pereira dos Santos, do Instituto Adolfo Lutz, muito obrigada pelo esforço em nos fornecer as micoplacas.

Ao Dr. Patrick Spencer, obrigada pela colaboração e apoio na parte experimental deste trabalho.

Ao Dr. Jorge Sarkis e Helena Miho Shihomatsu pelo suporte e apoio dado na parte experimental deste projeto.

Aos meus amigos Souza, Mara, Roberta, Carolina e Sirlene, do Laboratório de Biomateriais - IPEN, muito obrigada pelo carinho, apoio e comprrensão. 


\title{
ESTUDO DA INCORPORAÇÃO E LIBERAÇÃO DE UM EXTRATO \\ DE ALGAS VERMELHAS EM MEMBRANAS DE HIDROGEL
}

\author{
Renata Hage Amaral
}

\section{RESUMO}

Os hidrogéis estão dentre as matrizes poliméricas mais utilizadas em tecnologia farmacêutica em razão de sua vasta aplicação e funcionalidade, especialmente em sistema de liberação de fármacos. Tendo em vista o grande avanço nas inovações dos produtos cosméticos, tanto por meio da introdução de novos princípios ativos quanto pelas matrizes utilizadas para liberação controlada dos mesmos, o objetivo deste trabalho foi incorporar e avaliar a liberação de um princípio ativo natural, o $\operatorname{Arct}^{\prime} \mathrm{Alg}^{\circledR}$, em membranas de hidrogel, de modo a obter um dispositivo de liberação para fins cosméticos. O Arct'Alg ${ }^{\circledR}$ é um extrato aquoso que possui uma excelente ação anti-oxidante, lipolítica, anti-inflamatória e citoestimulante. Foi realizado o estudo das propriedades mecânicas, físicoquímicas e a biocompatibilidade in vitro das membranas de hidrogéis de poli(vinil2- pirrolidona) (PVP) e poli(vinil álcool) (PVA) obtidas pela reticulação por radiação ionizante. A caracterização físico-química das matrizes poliméricas foi obtida pelos ensaios de fração gel e intumescimento e o de biocompatibilidade in vitro pelo ensaio de citotoxicidade pelo método de incorporação do vermelho neutro. No ensaio de fração gel tanto o hidrogel de PVP quanto o de PVA apresentaram um alto grau de reticulação. O hidrogel de PVP apresentou uma maior porcentagem de intumescimento em relação ao de PVA e no ensaio de citotoxicidade os hidrogéis mostraram-se atóxicos. A propriedade citoestimulante do $\operatorname{Arct}^{\prime} A \mathrm{Ig}^{\circledR}$ foi verificada no ensaio de citoestimulação com células fibroblásticas de pele de coelho, em que foi evidenciado um aumento de cerca de $50 \%$ das células quando em contato com $0,5 \%$ do princípio ativo. As membranas de hidrogel preparadas com $3 \%$ de $\operatorname{Arct}^{\prime} \mathrm{Alg}^{\circledR}$ foram submetidas ao ensaio de liberação em incubadora a $37^{\circ} \mathrm{C}$ e as alíquotas coletadas durante o ensaio foram quantificadas por cromatografia líquida de alta eficiência (HPLC). Os resultados obtidos na cinética de liberação mostraram que as membranas de hidrogel de PVP liberaram cerca de $50 \%$ do Arct'Alg ${ }^{\circledR}$ incorporado e as de PVA em cerca de $30 \%$. No ensaio de citoestimulação do $\mathrm{Arct}^{\prime} \mathrm{Alg}^{\circledR}$ liberado, o dispositivo de PVP apresentou um aumento em cerca de $80 \%$ da população celular em relação ao controle do ensaio, mostrando ser o dispositivo mais indicado para ser utilizado em processos de reparação cutânea. 


\title{
IMMOBILIZATION AND RELEASE STUDY OF A RED ALGA EXTRACT IN HYDROGEL MEMBRANES
}

\author{
Renata Hage Amaral
}

\begin{abstract}
In pharmaceutical technology hydrogel is the most used among the polymeric matrices due to its wide application and functionality, primarily in drug delivery system. In view of the large advance innovations in cosmetic products, both through the introduction of new active agents as the matrices used for its controlled release, the objective of this study was to evaluate the release and immobilization of a natural active agent, the $\operatorname{Arct}^{\prime} \mathrm{Alg}^{\circledR}$ in hydrogel membranes to obtain a release device for cosmetics. Arct'Alg ${ }^{\circledR}$ is an aqueous extract which has excellent anti-oxidant, lipolytic, anti-inflammatory and cytostimulant action. Study on mechanical and physical-chemical properties and biocompatibility in vitro of hydrogel membranes of poly(vinyl-2- pyrrolidone) (PVP) and poly(vinyl alcohol) (PVA) obtained by ionizing radiation crosslinking have been performed. The physical-chemical characterization of polymeric matrices was carried out by gel fraction and swelling tests and biocompatibility by in vitro test of cytotoxicity by using the technique of neutral red incorporation. In the gel fraction test, both the PVP and PVA hydrogel showed a high crosslinking degree. The PVP hydrogel showed a greater percentage of swelling in relation to PVA and the cytotoxicity test of the hydrogels showed non-toxicity effect. The cytostimulation property of $\operatorname{Arct}^{\prime} \mathrm{Alg}^{\circledR}$ was verified by the cytostimulation test with rabbit skin cells, it was showed an increase at about $50 \%$ of the cells when in contact with $0,5 \%$ of active agent. The hydrogel membranes prepared with $3 \%$ of $\mathrm{Arct}^{\prime} \mathrm{Alg}^{\circledR}$ were subjected to the release test in an incubator at $37^{\circ} \mathrm{C}$ and aliquots collected during the test were quantified by high performance liquid chromatography (HPLC). The results obtained in the kinetics of release showed that the PVP hydrogel membranes released about $50 \%$ of Arct'Alg $^{\circledR}$ incorporated and the PVA hydrogel membranes at about $30 \%$. In the cytostimulation test of released Arct'Alg $^{\circledR}$, the PVP device showed an increase at about $80 \%$ of cell population in relation of test control, showing to be the greater device to be used in processes of skin repair.
\end{abstract}




\section{SUMÁRIO}

Página

1 INTRODUÇÃO 10

2 OBJETIVOS 12

3 REVISÃO DA LITERATURA 13

3.1 Pele humana 13

3.1.1 Epiderme 14

3.1.2 Derme 16

3.1.3 Vascularização da pele 17

3.2 Cicatrização 18

3.3 Polímeros 20

3.3.1 Ação da radiação ionizante sobre a matéria e polímeros 20

3.3.2 Reticulação e degradação de polímeros 22

3.3.3 Aplicações biomédicas dos polímeros 25

3.3.4 Hidrogéis 27

3.3.5 Poli(vinil álcool) 29

3.3.6 Poli(N-vinil-2-pirrolidona) 30

3.3.7 Ágar 32

3.3.8 Poli(etilenoglicol) 32

3.4 Arct'alg $^{\circledR}$

3.5 Sistema de liberação de fármacos 34

3.6 Citotoxicidade 39

3.7 Citoestimulação de fibroblastos e produção de colágeno 40

4 MATERIAIS E MÉTODOS 42

4.1 Materiais $\quad 42$

4.1.1 Matéria prima utilizada para síntese das matrizes de hidrogel 42

4.1.2 Princípio ativo 42

4.2 Métodos $\quad 42$

4.2.1 Obtenção das matrizes de hidrogel 42

4.2.2 Caracterização da matriz de hidrogel 43

4.2.2.1 Fração Gel 43

4.2.2.2 Intumescimento 44

4.2.2.3 Propriedades mecânicas 45 
4.2.2.4 Citotoxicidade 46

4.2.3 Preparo do dispositivo de hidrogel 47

4.2.3.1 Citoestimulação $\quad 47$

4.2.3.2 Estudo do comportamento do dipeptídeo citrulil-arginina irradiado 51

4.2.3.3 Incorporação do Arct'Alg ${ }^{\circledR}$ na matriz de hidrogel 52

4.2.4 Cinética de liberação e doseamento do Arct'Alg $^{\circledR}$

4.2.5 Atividade citoestimulante do Arct'Alg ${ }^{\circledR}$ liberado 53

5 RESULTADOS E DISCUSSÃO 55

5.1 Obtenção das matrizes de hidrogel 55

5.2 Caracterização da matriz de hidrogel 56

5.2.1 Fração Gel 56

5.2.2 Intumescimento $\quad 57$

5.2.3 Citotoxicidade $\quad 59$

5.2.4 Propriedades Mecânicas 61

5.3 Citotoxicidade do Act'Alg ${ }^{\circledR} \quad 64$

5.4 Citoestimulação 65

5.6 Estudo do comportamento do dipeptídeo irradiado 67

$\begin{array}{ll}5.7 \text { Obtenção do dispositivo de hidrogel } & 69\end{array}$

5.8 Cinética de liberação e doseamento do Arct'Alg ${ }^{\circledR} 70$

5.9 Atividade citoestimulante do Arct'Alg ${ }^{\circledR}$ liberado $\quad 79$

6 CONCLUSÃO 81

7 APÊNDICE 82

8 REFERÊNCIAS BIBLIOGRÁFICAS 91 


\section{LISTA DE FIGURAS}

Página

FIGURA 1. Camadas da pele 13

FIGURA 2. Camadas da epiderme 14

FIGURA 3. Representação esquemática dos plexos vasculares 17

horizontais: superficial e profundo

FIGURA 4. Formação da ligação entre as cadeias poliméricas: reticulação 23

FIGURA 5. Cisão de cadeia pricipal 24

FIGURA 6. Poli(vinil álcool) 29

FIGURA 7. Poli(N-vinil-2-pirrolidona) 30

FIGURA 8. Formação do radical polimérico 31

FIGURA 9. Poli(etilenoglicol) 33

FIGURA 10. Fórmula estrutural do dipeptídeo citrulil-arginina 34

FIGURA 11. Concentração de fármaco absorvido em função do tempo 35

FIGURA 12. Extrator de Soxhlet 44

FIGURA 13. Texturômetro da Micro System 45

FIGURA 14. Esquema da distribuição dos extratos das amostras e controle $\quad 47$ na microplaca.

FIGURA 15. Esquema da distribuição das diferentes concentrações de $\quad 50$ $\operatorname{Arct}^{\prime} \operatorname{Alg}^{\circledR}$ na microplaca 3.

FIGURA 16. Sistema de HPLC da Shimadzu 52

FIGURA 17. Matriz de hidrogel de PVP 55

FIGURA 18. Matriz de hidrogel de PVA 56

FIGURA 19. Perfil de intumescimento dos hidrogéis de PVP e PVA 59

FIGURA 20. Curvas de viabilidade celular dos hidrogéis de PVP e PVA 60

no ensaio de citotoxicidade pelo método de incorporação do vermelho neutro

FIGURA 21. Performance da força de tração aplicada à membrana de PVP 62

FIGURA 22. Performance da força de tração aplicada à membrana de PVA 62

FIGURA 23. Curvas de viabilidade celular do Arct'Alg ${ }^{\circledR} 65$

FIGURA 24. Viabilidade celular em função da concentração de $\operatorname{Arct'Alg}^{\circledR} \quad 66$

FIGURA 25. Cromatograma do citrulil-arginina irradiado 68

FIGURA 26. Cromatograma do citrulil-arginina não-irradiado 68

FIGURA 27. Dispositivo de hidrogel de PVA 70

FIGURA 28. Dispositivo de hidrogel de PVP 70 
FIGURA 29. Cromatograma da solução padrão de citrulil-arginina

FIGURA 30. Cromatograma de cinética de liberação do dispositivo

de PVP contendo Arct'Alg ${ }^{\circledR}$ após 1h de liberação.

FIGURA 31. Cromatograma do extrato da membrana controle de PVP

FIGURA 32. Cromatograma de cinética de liberação do dispositivo

de PVA contendo Arct'Alg $^{\circledR}$ após 1 h de liberação

FIGURA 33. Cromatograma do extrato da membrana controle de PVA

FIGURA 34. Cromatograma da análise em HPLC do dispositivo de

PVA contendo citrulil-arginina

FIGURA 35. Perfil de liberação do citrulil-arginina contido no $\operatorname{Arct}^{\prime} A{ }^{\circledR}{ }^{\circledR}$ do dispositivo de PVP

FIGURA 36. Perfil de liberação do citrulil-arginina contido no

Arct'Alg $^{\circledR}$ do dispositivo de PVA

FIGURA 37. Viabilidade celular do $\operatorname{Arct}^{\prime} A l g{ }^{\circledR}$ liberado na primeira

hora dos dispositivos de hidrogéis de PVP e PVA

FIGURA 38. Viabilidade celular em função da concentração de

Arct'Alg $^{\circledR}$ em microplaca contendo 200.000 céls $/ \mathrm{mL}$

FIGURA 39. Viabilidade celular em função da concentração de

Arct'Alg ${ }^{\circledR}$ em microplaca contendo 180.000 céls $/ \mathrm{mL}$

FIGURA 40. Viabilidade celular em função da concentração de

Arct'Alg ${ }^{\circledR}$ em microplaca contendo 150.000 céls $/ \mathrm{mL}$

FIGURA 41. Viabilidade celular em função da concentração de

Arct'Alg $^{\circledR}$ em microplaca contendo 100.000 céls $/ \mathrm{mL}$

FIGURA 42. Viabilidade celular em função do uso de MEM com

diferenetes concentrações de SFB

FIGURA 43. Viabilidade celular em função da concentração de

SFB no MEM + L-15

FIGURA 44. Viabilidade celular em função da concentração de

$\operatorname{Arct'}^{\prime} \mathrm{Alg}^{\circledR}$ com incubação da microplaca por $24 \mathrm{~h}$

FIGURA 45. Viabilidade celular em função da concentração de Arct'Alg $^{\circledR}$ com incubação da microplaca por 48 horas - ensaio 1

FIGURA 46. Viabilidade celular em função da concentração de Arct'Alg $^{\circledR}$ com incubação da microplaca por 48 horas - ensaio 2 



\section{INTRODUÇÃO}

Hidrogéis, ou géis contendo água, são polímeros caracterizados pela hidrofilicidade e insolubilidade em água (Kudela, 1990).

Os hidrógeis têm despertado grande interesse devido apresentarem características interessantes como, por exemplo, a biocompatibilidade. A utilidade dos hidrogéis como biomateriais encontra-se na similaridade de suas propriedades físicas com aquelas dos tecidos vivos, fazendo-os úteis para uma grande variedade de aplicações biomédicas, como curativos, implantes, lentes de contato, matriz para imobilização de enzimas e sistemas de liberação controlada e/ou sustentada de princípios ativos (Peppas, 1996).

Bandagem de hidrogel à base de poli(N-vinil-pirrolidona) (PVP) e poli(etilenoglicol) (PEG) foi originalmente inventada como curativo para o tratamento de queimadura por Rosiak e colaboradores (1989). No entanto, atualmente, este sistema polimérico é amplamente aplicado como sistema de liberação de fármacos entre outros. O sucesso desses sistemas está relacionado com as propriedades da matriz e a tecnologia de fabricação das mesmas.

Inicialmente os sistemas de liberação de fármacos foram desenvolvidos para rotas tradicionais de administração, como oral e intravenoso, porém, recentemente ocorreu um aumento nas pesquisas que visam à utilização de rotas consideradas não tradicionais como nasal, ocular, pulmonar, vaginal, retal e transdérmica (ZHANG et al., 2004).

Durante décadas a pele tem sido utilizada como via de administração de substâncias dermatologicamente ativas, ou seja, com ação farmacológica nos tecidos da pele. Nessas terapias considera-se que as moléculas do fármaco difundem-se para o tecido no local da aplicação para produzir seus efeitos terapêuticos (Chien, 1987).

Uma das principais aplicações das membranas de hidrogel é sobre o tecido cutâneo lesionado, por serem flexíveis, não tóxicas e possibilitarem a aplicação tópica de fármacos por meio da membrana (Rosiak, 1991). 
Tendo em foco o desenvolvimento de um novo produto para a regeneração cutânea, na área cosmética, este trabalho teve por objetivo o estudo da incorporação e liberação de um princípio ativo natural, o $\operatorname{Arct}^{\prime} \mathrm{Alg}^{\circledR}$, em membranas de hidrogel. Este princípio ativo foi escolhido por possuir em sua composição o dipeptídeo citrulil-arginina que apresenta propriedades biológicas como ação anti-oxidante, citoestimulante, lipolítica e anti-inflamatória. A escolha de hidrogéis de PVP e PVA como matrizes para incorporar e liberar este princípio ativo foi motivada pela comprovada biocompatibilidade e alto grau de intumescimento dos mesmos. Partindo do pressuposto de que o princípio ativo não se liga ao polímero, realizou-se o ensaio de liberação do $\operatorname{Arct}^{\prime} A{ }^{\circledR}{ }^{\circledR}$ a partir dos hidrogéis para verificar o seu perfil de liberação e uma possível viabilidade comercial deste dispositivo. 


\section{OBJETIVOS}

O objetivo principal deste trabalho foi o estudo da incorporação do Arct'Alg $^{\circledR}$ em membranas de hidrogel de poli(N-vinil-pirrolidona) (PVP) e poli(vinil álcool) (PVA) obtidas pela radiação ionizante e cinética de liberação do mesmo. Para alcançar este objetivo foram realizadas as seguintes etapas:

- Caracterizar o hidrogel de PVP e PVA;

- Estudar a incorporação do Arct'Alg $^{\circledR}$ na matriz polimérica;

- Analisar a liberação in vitro do Arct'Alg ${ }^{\circledR}$;

- Verificar in vitro a propriedade de citoestimulação do Arct'Alg ${ }^{\circledR}$ em cultura de células fibroblásticas. 


\section{REVISÃO DA LITERATURA}

\subsection{Pele humana}

A pele é o maior órgão do corpo humano, ocupando área média de 2 $\mathrm{m}^{2}$, o que corresponde a cerca de 10 a $15 \%$ do peso total corporal (Leonardi \& Matheus, 2008). Ela é formada por tecidos de origem ectodérmica e mesodérmica que se arranjam em três camadas distintas: a epiderme, a derme e a hipoderme. Esta última não é considerada por muitos autores como parte integrante da pele, embora seja estudada dentro do sistema tegumentar (Sousa \& Vargas, 2004).

As camadas da pele humana estão ilustradas na FIG. 1

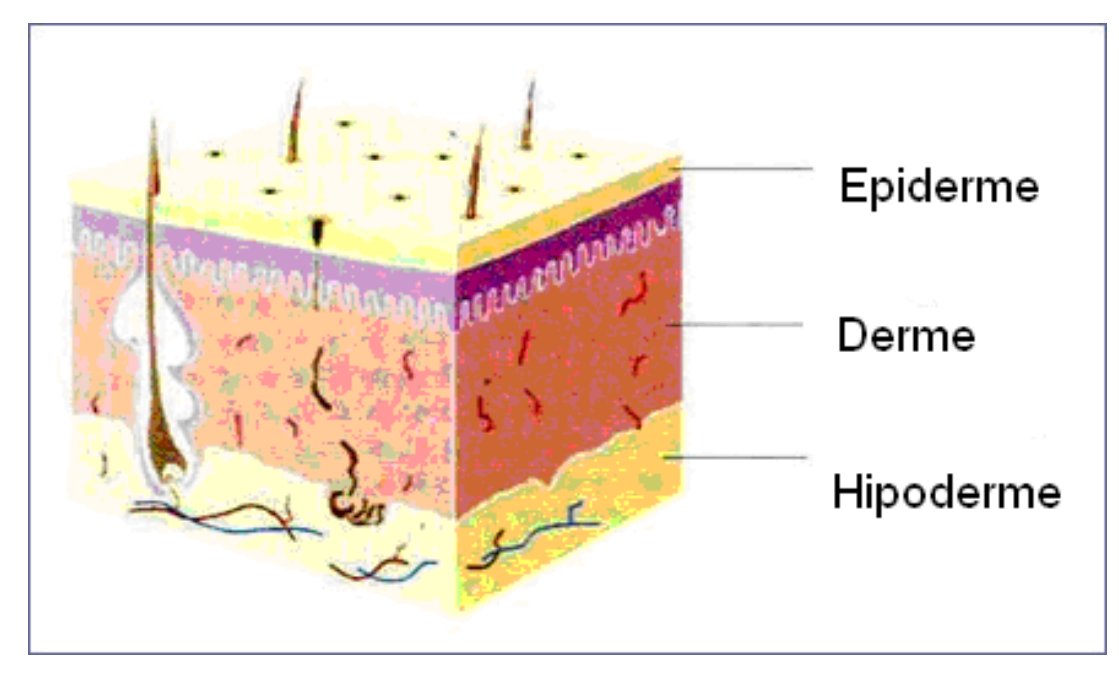

FIGURA 1. Camadas da pele.

O tegumento, mesmo sem restringir a maleabilidade do corpo humano, constitui uma barreira eficiente contra agressões exógenas, de natureza química ou biológica e impede a perda de água e de proteínas para o exterior. A pele também age como órgão sensorial, participa do sistema imunológico e exerce outras funções, como a regulação da temperatura corpórea, a produção de vitamina D3, a excreção de eletrólitos e outras substâncias e confere uma proteção relativa para os órgãos internos (Sousa \& Vargas, 2004). 
A espessura da pele varia dependendo da área do corpo, sendo a pele mais espessa encontrada nas regiões sujeitas a pressões e atritos constantes (Ribeiro, 2006).

\subsubsection{Epiderme}

A epiderme, de origem ectodérmica, é um epitélio de revestimento estratificado e pavimentoso por possuir várias camadas de células que vão se achatando à medida que se tornam mais superficiais. Como todo epitélio, as células da epiderme se renovam indefinidamente devido a uma atividade mitótica contínua. A principal função da epiderme é produzir queratina, uma proteína fibrosa maleável, responsável pela impermeabilidade cutânea, e as células que estão envolvidas nesta função são denominadas queratinócitos (Sousa \& Vargas, 2004).

As camadas que formam a epiderme são conhecidas como basal, espinhosa, granulosa e córnea (FIG. 2). Uma quinta camada, a lúcida, é encontrada entre as camadas córnea e granulosa na palma das mãos e sola dos pés, conferindo maior espessamento da pele nestas regiões (pele espessa), ao contrário das demais regiões do corpo onde a pele é mais fina (pele delgada) (Ribeiro, 2006).

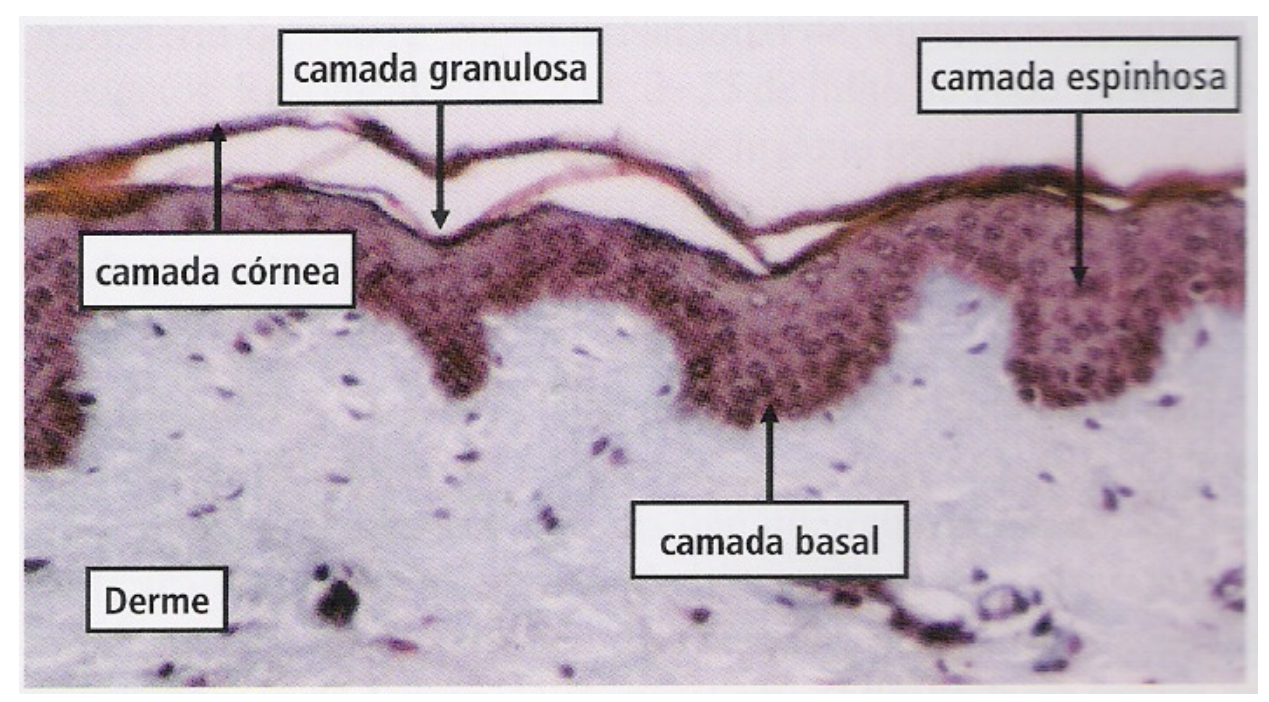

FIGURA 2. Camadas da epiderme 
As células da epiderme constituem um sistema dinâmico, ou seja, estão em constante renovação, desde sua junção com a derme até a sua superfície cutânea, onde se efetua uma descamação permanente (Leonardi \& Matheus, 2008).

O estrato basal é chamado também de estrato germinativo, por conter células em divisão. As células recém produzidas migram em direção às camadas superiores da epiderme, com a finalidade de substituir as que descamaram. Logo, na camada germinativa originam-se as células epidérmicas, que vão pouco a pouco ganhando a superfície, sofrendo modificações graduais na forma e na composição química, até se tornarem anucleadas (na camada córnea) e se esfoliarem. Há, assim, um deslocamento permanente e repetido de células, que da camada basal atingem gradualmente a superfície da epiderme para se desprenderem já mortas (Leonardi \& Matheus, 2008).

O ciclo de queratinização, ou corneificação, consiste nesta transformação das células epiteliais em células córneas. A pele elimina diariamente cerca de 6 a $14 \mathrm{~g}$ de células mortas, que são substituídas por outras células epidérmicas, as quais gradualmente se queratinizam (Leonardi \& Matheus, 2008).

O tempo que um queratinócito basal leva para se tornar um queratinócito córneo é duas semanas, e o mesmo período de tempo é gasto para que o queratinócito córneo venha a descamar. Portanto, a epiderme tem a sua população queratinocítica renovada a cada quatro semanas, em condições habituais (Sousa \& Vargas, 2004).

Acima da camada basal encontra-se a espinhosa, formada por várias fileiras de células, sendo as mais profundas poliédricas e as superficiais mais achatadas (Ribeiro, 2006). Apresentam prolongamentos citoplasmáticos na forma de espinhos que formam pontes entre as células adjacentes chamadas desmossomos, os quais são responsáveis pela manutenção da integridade da epiderme. Entre esses prolongamentos há um espaço preenchido com tecido fluido que separa as células vizinhas e permite que nutrientes e oxigênio difundam-se em direção às demais camadas da epiderme (Barry, 1983).

Os corpos lamelares, reconhecidos como o primeiro sinal de queratinização, surgem no estrato espinhoso. Esses grânulos contêm lipídeos 
como ceramidas, ácidos graxos e colesterol, além de proteases, fosfatases ácidas, lípases e glicosidases (Baumann \&Weisberg, 2002).

A camada granulosa, com a espessura de duas ou três camadas de células carregadas em grânulos de querato-hialina, situa-se entre a camada córnea e a camada espinhosa (Ribeiro, 2006).

Esta região da epiderme é a responsável pela formação da bicamada de lipídeos presente entre as fileiras de células corneificadas que formam a camada córnea. Esta estrutura lamelar tem como função prevenir a desidratação das camadas subjacentes da epiderme, formar barreira e oferecer resistência à absorção percutânea, além de atuar como "cimento", fixando as células queratinizadas umas às outras, impedindo o seu desprendimento (Ribeiro, 2006).

A última camada da epiderme, a córnea, é o resultado final do processo de diferenciação celular pelo qual passam os queratinócitos e que começa na camada germinativa ou basal (Ribeiro, 2006).

A porção menos permeável da epiderme é o estrato córneo, onde as células são mais queratinizadas e o teor de lipídeos é mais elevado. Depois que uma molécula atravessa este estrato não há outra barreira à difusão para outras camadas da pele (Leonardi \& Matheus, 2008).

As células do estrato córneo são muito ricas em queratina e não possuem núcleo e nenhuma organela. Embora seja uma membrana muito fina, o estrato comporta-se como uma eficiente barreira, protegendo nosso corpo da desidratação. Os lipídeos disponíveis neste estrato formam membranas lamelares intercelulares que retêm água, conservando a superfície da nossa pele saudável e macia (Leonardi \& Matheus, 2008).

\subsubsection{Derme}

A derme consiste em um tecido resistente e elástico que proporciona resistência física ao corpo frente a agressões mecânicas, fornece nutrientes à epiderme e abriga os apêndices cutâneos, vasos sanguíneos e linfáticos, células de natureza conjuntiva e de origem sanguínea (Ribeiro, 2006).

É dividida em duas regiões, a porção superior conhecida como derme papilar, sendo a camada inferior à epiderme e que apresenta maior densidade de elementos vasculares, e a outra logo abaixo, a derme reticular que possui maiores feixes de fibras colágenas (Baumann \&Weisberg, 2002). 
O colágeno é sintetizado no retículo endoplasmático do fibroblasto, iniciado pelo pró-colágeno que por ação de peptidases se transforma em tropocolágeno, rico em aminoácidos lisina e prolina, que sofrem hidroxilação para transformar o tropocolágeno em colágeno, este rico em hidroxilisina e hidroxiprolina. Fazem parte desta reação bioquímica os cofatores silício orgânico, ácido ascórbico, magnésio e cálcio (Leonardi \& Matheus, 2008).

As fibras elásticas permitem extensa deformação da pele, que retorna passivamente ao estado original quando suspensa a força aplicada (Ribeiro, 2006). Essas fibras estão reunidas em feixes de microfibrilas compostas de fibrilina. A fibrilina forma um molde, sobre o qual a elastina é depositada. As fibras elásticas estão localizadas na periferia dos feixes de fibras colágenas e formam uma rede estrutural na derme e, juntamente com o colágeno, respondem pelas propriedades mecânicas dos tecidos conectivos (Baumann \&Weisberg, 2002).

\subsubsection{Vascularização da pele}

A derme possui dois plexos vasculares horizontais, um superficial e outro profundo (FIG. 3). Esta rede vascular é de fundamental importância para a nutrição da epiderme, que não é vascularizada (Ribeiro, 2006).

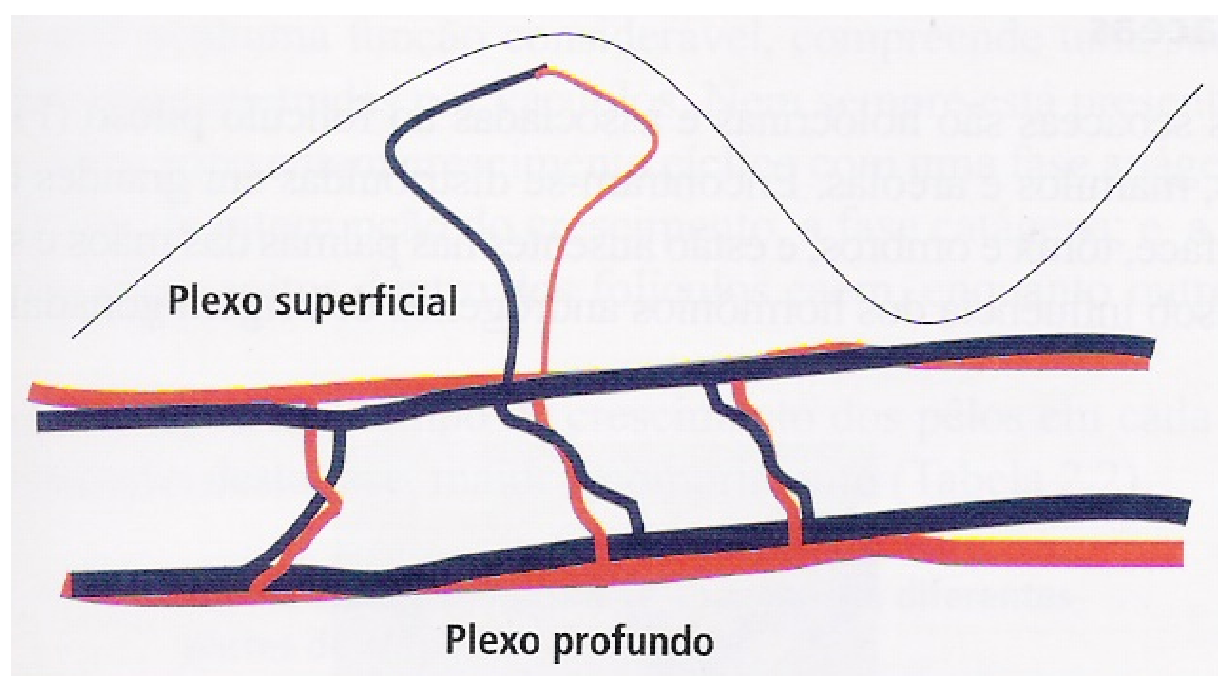

FIGURA 3. Representação esquemática dos plexos vasculares horizontais: superficial e profundo.

O plexo superficial situa-se na porção superficial da derme reticular, com arteríolas pequenas, de camada muscular descontínua, e delas partem alças 
capilares com sangue arterial que ascendem até o topo de cada papila dérmica e retornam como papilares venosos (Sousa \& Vargas, 2004).

O plexo profundo situa-se na base da derme reticular e é composto por arteríolas e vênulas de parede muscular contínua. Há íntima ligação dos dois plexos, pois das arteríolas do plexo profundo, sobem vasos que se ligam no plexo superficial (Sousa \& Vargas, 2004).

\subsection{Cicatrização}

O processo de cicatrização se dá fundamentalmente no tecido conjuntivo, no qual diversos fatores de ordem geral ou local intervêm em sua constituição e função. A cicatriz consiste na substituição do tecido lesado por tecido conjuntivo neoformado, indicado como cicatricial (Guirro, 2002).

A reparação cutânea é constituída por uma sucessão de fenômenos complexos e estreitamente ligados, que podem ser classificados em diferentes etapas ou fases (Guirro, 2002):

- Fase inflamatória: Fase inicial e fundamental do processo de reparo que dura em média 72 horas desencadeada pela lesão, independentemente de seu agente etiológico. Numa primeira etapa, observa-se uma vasoconstrição, que é fugaz, seguida pela liberação de substâncias vasoativas (histamina, serotonina, 5-hidroxi-triptamina, cininas, plasmina, calicreína e prostaglandinas PgE1 e PgE2), capazes de promover aumento da permeabilidade vascular. O fluido originado do exudato é principalmente o plasma, que coagula, delimitando o processo.

- Fase de latência: Essa fase é assim denominada em virtude de se acreditar inicialmente que havia uma interrupção na cicatrização, porém atualmente sabe-se que é uma fase bastante ativa. Substâncias denominadas fatores de crescimento (cininas) estão aumentadas em nível sérico em torno do sexto dia, e atuam em diversas fases da proliferação celular.

- Fase de fibroplasia (biossíntese do colágeno): a ação de macrófagos inicia a transição para essa segunda fase do reparo da lesão em que se desenvolve a formação do tecido de granulação. O tecido de granulação consiste de uma 
densa população de macrófagos, fibroblastos e novos vasos, embebidos em uma matriz frouxa de colágeno, fibronectina e ácido hialurônico.

- Fase de contração: Fase dinâmica que objetiva a redução da superfície cruenta, produzindo a aproximação das bordas da lesão, contribuindo para o fechamento da mesma. Esta fase tem início entre o sétimo e o décimo quarto dias de lesão.

A cicatrização processa-se na maioria das vezes de forma rápida e satisfatória. No entanto, fatores como estado nutricional, doença preexistente, uso de vestimenta, exposição à terapia com radiação, álcool e fumo podem influenciar neste processo de regeneração da pele (Sousa \& Vargas, 2004).

$O$ processo de cicatrização pode ser classificado segundo o tipo e a quantidade de tecido em cicatrização por primeira intenção e cicatrização por segunda intenção. A primeira ocorre em casos de incisões cirúrgicas limpas nãoinfectadas, cujas bordas são aproximadas por suturas. A lesão provoca a morte de um número limitado de células epiteliais e do tecido conjuntivo, além da ruptura da continuidade da membrana basal epitelial. A reação inflamatória é mais branda e ao final do processo observa-se uma cicatriz formada por tecido conjuntivo destituído de infiltrado inflamatório recoberto por uma epiderme intacta. Cicatrização por segunda intenção ocorre quando há uma perda extensa de células e tecido que deve ser preenchida, como na ulceração inflamatória, formação de abscesso e em feridas superficiais que geram grandes defeitos. Observa-se uma reação inflamatória mais intensa e são necessárias a regeneração das células parenquimatosas e a formação de um tecido de granulação abundante para completar o reparo tecidual. Grandes feridas de superfície podem sofrer contração, um efeito possivelmente causado pela presença de miofibroblastos, que resulta na redução do tamanho da lesão ao final do processo cicatricial (Cotran et al., 2000).

As cicatrizes podem ser classificadas em (Sousa \& Vargas, 2004):

- Atróficas: lesões lisas, planas, retráteis, sem sulcos, poros e pêlos, acompanhadas de discromia. 
- Hipertróficas: lesões discrômicas, fibróticas, lisas, salientes, sem sulcos, poros e pêlos. São limitadas à área do processo cicatricial inicial, seu tamanho tende a diminuir ao longo dos anos.

- Queloidianas: salientes, duras, com superfície lisa e brilhante, de coloração rósea ou castanha e que apresenta dor e/ou prurido.

\subsection{Polímeros}

\subsubsection{Ação da radiação ionizante sobre a matéria e polímeros}

A química das radiações consiste no estudo dos efeitos químicos produzidos quando a matéria é exposta à radiação de energia alta, ou também denominada, radiação ionizante. Geralmente, os tipos de radiação mais conhecidos são aqueles produzidos pela decomposição de núcleos radioativos (radiação $\alpha, \beta$ e $\gamma$ ), partículas reativas de alta energia (elétrons, prótons, etc.) e radiação eletromagnética de onda curta (raios X) (Spinks \& Woods, 1990).

Quando a radiação eletromagnética interage com a matéria ocorrem vários processos de atenuação, sendo os três principais: efeito fotoelétrico, efeito Compton e produção de pares (Spinks \& Woods, 1990).

- Efeito fotoelétrico: ocorre principalmente com fótons de baixa energia (menor que $1 \mathrm{MeV}$ ), que interagem predominantemente pelo efeito fotoelétrico. Neste tipo de interação, toda a energia do fóton é transferida para um único elétron atômico, que é ejetado com uma energia igual à diferença entre a energia do fóton e a energia de ligação do elétron ao átomo. A ocorrência de interações fotoelétricas é mais provável em materiais com número atômico elevado e para fótons de baixa energia.

- Efeito Compton: ocorre quando um fóton interage com um elétron que pode estar fracamente ligado ou livre, sendo que o elétron é acelerado e o fóton defletido com energia reduzida. A energia do fóton incidente é dividida entre $o$ fóton espalhado e o elétron. $A$ interação Compton ocorre 
predominantemente para fótons com energia entre 1 e $5 \mathrm{MeV}$ em materiais com elevado número atômico .

- $\quad$ Produção de pares: a produção de pares envolve a completa absorção de um fóton nos arredores de um núcleo atômico ou, menos freqüentemente, um elétron com formação de duas partículas, um elétron e um pósitron. $A$ produção de pares não ocorre com fótons de energia menor que 1,02 MeV (Spinks \& Woods, 1990).

A interação da radiação ionizante com a matéria promove eventos físico-químicos, em nível atômico, os quais são complexos e podem ser divididos em três etapas consecutivas e distintas: etapa física, etapa físico-química e etapa química (Farhataziz \& Rodgers, 1987).

$\mathrm{Na}$ etapa física $\left(10^{-18}\right.$ a $\left.10^{-15} \mathrm{~s}\right)$, devido à ação da radiação sobre a matéria, ocorre transferência de energia. Esta energia transferida provoca excitações eletrônicas e ionização. As espécies primárias formadas com alta energia são muito instáveis, sofrendo reações secundárias (Farhataziz \& Rodgers, 1987).

Na etapa físico-química $\left(10^{-15}\right.$ a $\left.10^{-11} \mathrm{~s}\right)$ ocorre a formação de espécies secundárias reativas $\left(\mathrm{H}^{+}\right.$, radicais livres, etc.) que podem se originar de uma única reação ou podem resultar de uma sucessão complexa de reações (Farhataziz \& Rodgers, 1987).

A etapa química $\left(10^{-11} \mathrm{~s}\right.$ em diante) se inicia quando o sistema restabelece o equilíbrio térmico que havia sido alterado pela transferência de energia da radiação. As espécies reativas continuam a reagir entre si e com outras espécies vizinhas. O tempo de duração desta etapa depende do meio (sólido, líquido, etc.) em que a radiação vai interagir (Farhataziz \& Rodgers, 1987).

As mudanças químicas produzidas em um polímero quando exposto à radiação não são muito diferentes das observadas em compostos de massa molar baixo (Charlesby, 1960). Nem todas as moléculas poliméricas possuem o mesmo tamanho, e muitas de suas propriedades não estão relacionadas somente com a massa molar, mas com sua distribuição (Farhataziz \& Rodgers, 1987).

Basicamente, na irradiação de polímeros, os objetivos são a modificação das propriedades físicas como o comportamento mecânico, condutividade, ponto de fusão, entre outros (Farhataziz \& Rodgers, 1987). 
Os principais efeitos da radiação sobre os polímeros são: cisão da cadeia principal, com conseqüente redução da massa molar; reticulação, com conseqüente aumento da massa molar (podendo formar uma rede tridimensional insolúvel) e formação de insaturações. Como conseqüência da modificação estrutural do polímero irradiado pode ser verificada alterações de suas características morfológicas como, por exemplo, perda da cristalinidade e alteração de cor (Reichmanis \& O'Donnell, 1989).

A reticulação de materiais poliméricos pode ser iniciada por uma dissociação do hidrogênio ou por um radical que abstrai um hidrogênio de uma cadeia polimérica próxima formando um sítio reativo adicional. Para cada excitação-ionização, um radical polimérico e um átomo de hidrogênio são formados. Estes átomos de hidrogênio podem retirar outro hidrogênio e formar um radical polimérico adicional, ou também percorrer uma longa distância e sofrer várias colisões antes de abstrair um segundo hidrogênio, produzindo radicais poliméricos em outros locais (Bradley, 1984).

Alguns polímeros, após exposição à radiação de alta energia, mostram um aumento na massa molar, levando a formação de uma rede tridimensional (reticulação), já outros mostram uma redução na sua massa molar, ocorrendo mudanças na viscosidade e propriedades mecânicas. Estas mudanças podem ser devido a uma cisão na cadeia principal, induzida pela radiação, ocorrendo um rearranjo dos átomos perto do ponto de ruptura para estabilizar os grupos finais (degradação) (Charlesby, 1960).

As modificações causadas pela radiação ionizante em polímeros dependem das condições de processo, ou seja, tipo de radiação, presença de oxigênio ou diferentes atmosferas, aditivos, solventes, grau de cristalinidade e homogeneidade do material polimérico que irá absorver a energia, etc (Clegg \& Collyer, 1964).

\subsubsection{Reticulação e degradação de polímeros}

A radiação ionizante pode produzir a cisão ou reticulação de moléculas poliméricas, levando a diminuição ou o aumento do peso molecular (Clough \& Shalaby, 1991). 
Na reticulação ocorre uma ligação entre as cadeias poliméricas (FIG.4) formando uma rede tridimensional (Charlesby, 1960). Dentre os mecanismos propostos para a reticulação pode-se citar os seguintes (Schnabel, 1981):

- $\quad$ Quebra da ligação C-H de uma cadeia polimérica com a formação de um átomo de hidrogênio seguido da retirada de um segundo átomo de uma molécula próxima formando hidrogênio molecular $\left(\mathrm{H}_{2}\right)$. Sendo assim, os dois radicais poliméricos combinam-se formando uma reticulação;

- $\quad$ Migração de radicais produzidos pela quebra das ligações C-H ao longo das cadeias poliméricas até que duas delas tornem-se adjacentes e se unam formando a reticulação;

Estes processos podem ocorrer de forma individual ou concomitantemente. Apesar de nenhuma destas explicações ser completamente aceita, admite-se que para cada excitação ou ionização, um radical polimérico e um átomo de hidrogênio, devido a sua energia cinética, produzem radicais poliméricos secundários. Pares de radicais adjacentes, formados pela radiação ou por átomos de hidrogênio, podem unir-se (Schnabel, 1981).
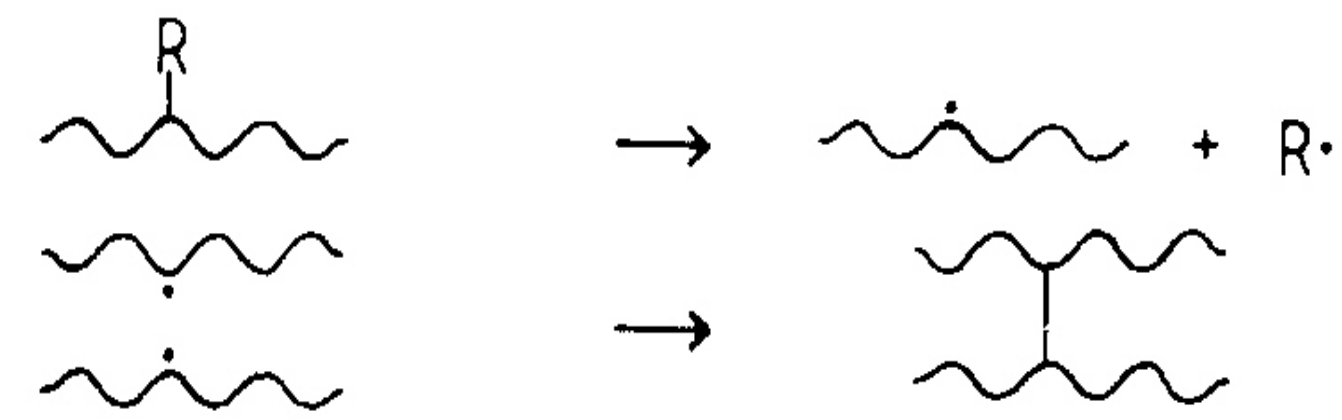

FIGURA 4. Formação da ligação entre as cadeias poliméricas: reticulação.

O fator mais importante que influencia na capacidade de intumescimento do hidrogel é a reticulação. Os hidrogéis altamente reticulados possuem uma estrutura mais apertada diminuindo o intumescimento em comparação com hidrogéis menos reticulados. A reticulação diminui a mobilidade 
da cadeia polimérica, por isso diminui a capacidade de intumescimento do hidrogel (Peppas, et al., 2000).

O uso da radiação de alta energia para promover a reticulação entre moléculas adjacentes do polímero é uma das principais aplicações industriais das radiações (Farhataziz \& Rodgers, 1987).

O termo degradação polimérica é usado para denotar as mudanças nas propriedades físicas causadas por reações químicas envolvendo cisão de cadeia na macromolécula (Schnabel, 1981). A degradação polimérica consiste na redução da massa molar do polímero e de mudanças em sua estrutura química (O’Donnell, 1991).

A cisão de cadeia (FIG. 5) é um efeito importante da radiação sobre os polímeros. As reações de competição entre a cisão de cadeia e a reticulação ocorrem simultaneamente em muitos sistemas poliméricos, a predominância de uma dessas reações irá depender das condições de irradiação e da estrutura química do polímero. Apesar das reações de cisão ser geralmente consideradas uma deterioração, alguns produtos industriais usam esta reação de degradação para produzir produtos comerciais (Bradley, 1984).

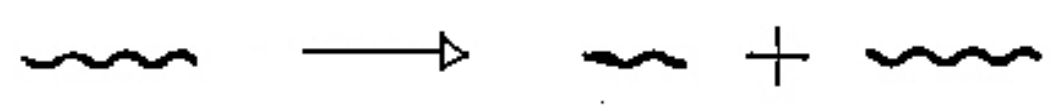

FIGURA 5. Cisão de cadeia pricipal

Em materiais como a celulose, o poliisobutileno e o polipropileno a cisão da cadeia, ou redução da massa molar é predominante. Já em poliamidas, poliacrilatos e polivinil álcool, a reação de reticulação é a predominante (Bradley, 1984).

O polímero pode sofrer degradação por outros processos, como a degradação química, enzimática, mecânica, biodegradação, etc., além da degradação por meio da radiação (Schnabel, 1981). 


\subsubsection{Aplicações biomédicas dos polímeros}

Atualmente, o maior grupo de materiais usados para fins biomédicos são os polímeros, que podem ser utilizados separadamente ou em combinações com outros materiais (Rosiak et al.,1995).

A aplicação de polímeros sintéticos na área médica tem crescido substancialmente nos últimos 30 anos. Na TAB. 1 são mostradas algumas das aplicações dos polímeros sintéticos na medicina (Peppas et al., 2000).

TABELA 1: Aplicações biomédicas dos polímeros.

\begin{tabular}{|c|c|c|c|}
\hline \multirow{2}{*}{$\begin{array}{l}\text { Instrumentos } \\
\text { médicos } \\
\text { cirúrgicos } \\
\end{array}$} & \multicolumn{2}{|c|}{$\begin{array}{l}\text { Sistemas substituintes ou melhoradores de } \\
\text { partes do corpo }\end{array}$} & \multirow[t]{2}{*}{$\begin{array}{c}\text { Sistemas com função } \\
\text { terapêutica }\end{array}$} \\
\hline & Externamente & Internamente & \\
\hline Seringas & Lentes de contato & $\begin{array}{l}\text { Próteses } \\
\text { ortopédicas } \\
\text { Implantes } \\
\text { cardiovasculares }\end{array}$ & $\begin{array}{c}\text { Sistema de liberação de } \\
\text { fármacos }\end{array}$ \\
\hline Catéteres & $\begin{array}{l}\text { Bombas de insulina } \\
\text { Rins artificiais }\end{array}$ & $\begin{array}{l}\text { "Stents" } \\
\text { Mamoplastia }\end{array}$ & Biosensores \\
\hline Curativos & $\begin{array}{l}\text { Fígados artificiais } \\
\text { Peles artificiais }\end{array}$ & $\begin{array}{l}\text { Reconstrução maxilofacial } \\
\text { Reconstrução das cordas } \\
\text { Vocais }\end{array}$ & Bombas de insulina \\
\hline Suturas & $\begin{array}{l}\text { Reconstrução de órgãos } \\
\text { Sexuais } \\
\text { Cartilagem articular }\end{array}$ & Tendões artificiais & \\
\hline
\end{tabular}

O polímero para ser considerado um biomaterial deve preencher alguns requisitos como (Rosiak et al.,1995):

- não-toxicidade: os materiais não devem ser pirogênicos ou carcinogênicos e não devem provocar inflamações crônicas; 
- funcionalidade: os biomateriais devem substituir temporariamente ou para a vida toda os órgãos e tecidos que estão com suas funções comprometidas;

- estéril: devem ser facilmente esterilizáveis em autoclave ou radiação ionizante;

- biocompatibilidade: o biomaterial deve causar o mínimo de stress ao organismo receptor, ou seja, não causar nenhum dano as células e tecidos.

Polímeros são moléculas de cadeia longa que consiste de um número de pequenas unidades repetidas, as quais se denominam monômeros. Vários tipos de polímeros são utilizados em aplicações biomédicas como os homopolímeros e os copolímeros (Visser et al.,1996).

A radiação ionizante produz íons e radicais livres que podem iniciar a polimerização ou a copolimerização em monômeros e degradação e reticulação em polímeros (Schnabel, 1981). O uso da radiação ionizante para a formação de biomateriais poliméricos possui algumas vantagens como (Rosiak, 1991):

- reticulação e esterilização simultânea do produto;

- O processo de reticulação pode ocorrer em uma ampla faixa de temperatura sem necessitar de um aquecimento para ocorrer à reação no sistema;

- Propriedades físicas e/ou químicas do produto final podem ser obtidas pelo ajuste da intensidade e tipo de radiação, tempo de irradiação (dose), etc.

O curativo de hidrogel a base de PVP utilizado em queimaduras e ulcerações da pele utiliza a radiação ionizante para obter a reticulação do polímero e simultânea esterilização do produto (Rosiak, 1991).

Há também outros tipos de hidrogéis utilizados como curativos reportados na literatura, hidrogéis de PVP e PVA (Razzak et al., 2001) e de poli óxido de etileno (PEO) e PVA (Yoshii et al., 1999) obtidos por radiação gama, e de PVA intumescidos com quitosana (Rodas et al., 2005) são alguns exemplos.

Desde a década de 1980, folhas de silicone na forma de gel têm sido testadas no tratamento de escaras hipertróficas e quelóides apresentando bons 
resultados. Estudos demonstraram que as bandagens de silicone em gel são seguras e efetivas para essa aplicação, podendo ser especialmente úteis para crianças e outros pacientes intolerantes à dor e a outros procedimentos (Valenta \& Auner, 2004).

Outro produto muito utilizado no tratamento de feridas que requeiram enxerto é o Integra ${ }^{\circledR}$. Ele é constituído por membrana de colágeno que quando colocado sobre a ferida sofre invasão dos vasos sanguíneos promovendo sua vascularização. Após algum tempo esta membrana é degradada pelo organismo e substituída por tecido do próprio paciente (Jones et al., 2002).

\subsubsection{Hidrogel}

Hidrogéis, ou géis contendo água, são polímeros caracterizados pela hidrofilicidade e insolubilidade em água. Na água, eles intumescem até atingir o equilíbrio preservando a sua forma (Kudela, 1990).

A hidrofilicidade do hidrogel é devido a presença de grupos hidrofílicos em água como $-\mathrm{OH},-\mathrm{COOH},-\mathrm{CONH}$, etc. A insolubilidade e estabilidade de sua forma em água são devido a presença da rede tridimensional (Kudela, 1990).

Os hidrogéis podem ser classificados em vários tipos, dependendo do seu método de preparo, carga iônica, ou características físicas estruturais (Peppas, 1996).

A síntese do hidrogel pode ser a partir de qualquer polímero hidrofílico que possa ser reticulado formando uma rede tridimensional. A reticulação pode ser feita por reação química, radiação ionizante ou interações físicas (Gehrke \& Lee, 1990).

A reticulação por reação química necessita de um agente iniciador. Este agente normalmente liga as cadeias de massa molar maior através de seus grupos multifuncionais. Um segundo método utilizado é a reação de copolimerização entre um ou mais monômeros e um monômero multifuncional, que é presente em menor quantidade. Outro método utilizado envolve o uso da combinação de um monômero e uma cadeia polimérica linear que são reticulados por um agente químico (Peppas, 1996).

A formação de hidrogéis via radiação ionizante pode ser definida como resultado de combinação mútua de macrorradicais. Estes macrorradicais são produtos obtidos pela interação da radiação com a matéria prima, formando 
produtos reativos como íons e estados excitados, que perdem sua energia formando radicais livres. Se estes radicais estiverem localizados em cadeias poliméricas diferentes e posicionados favoravelmente, podem sofrer recombinações havendo a formação de ligação covalente entre as cadeias (Rosiak \& Olejniczak, 1993).

$\mathrm{Na}$ reticulação por radiação ionizante ocorre a interconecção das cadeias poliméricas longas por meio de ligações covalentes. Nos hidrogéis físicos (géis reversíveis, pseudogéis) também é formada uma rede tridimensional, mas as cadeias poliméricas individuais são conectadas por pontes de hidrogênio ou interações eletrostáticas. Neste caso é normalmente possível converter este tipo de hidrogel em uma solução homogenia. Os exemplos clássicos de alguns são gelatina e ágar (Rosiak, 1991).

O processo de formação de hidrogéis por radiação ionizante possui algumas vantagens, como por exemplo, obter a reticulação e esterilização simultânea do produto, possibilidade de reticulação em temperaturas baixas e ausência de iniciadores químicos (Rosiak et al.,1995).

A habilidade de absorver água e íons, sem perder sua forma e suas propriedades mecânicas é uma das principais características do hidrogel. Outra propriedade importante de alguns hidrogéis é a biocompatibilidade em contato com o sangue, fluidos corpóreos e tecidos vivos (Rosiak, 1991).

As propriedades físicas dos hidrogéis fazem com que eles tenham uma ampla aplicação no campo biomédico e farmacêutico, sendo utilizados como curativos, lentes de contato, matrizes para imobilização de enzimas e sistemas de liberação de fármacos (Peppas, 1996).

Um dos hidrogéis mais utilizados é o PHEMA. Este foi apresentado como um material biológico por Wichterle e Lim em 1960. A estrutura do PHEMA permite um conteúdo de água similar ao do tecido vivo. Este hidrogel é inerte ao organismo, resistente a degradação e não é absorvido pelo corpo (Peppas, 1996).

Rosiak e colaboradores (1989) desenvolveram um sistema polimérico à base de poli(N-vinil-pirrolidona) (PVP), polietilenoglicol (PEG) e ágar, reticulado por feixe de elétrons de alta energia, com excelentes características para ser utilizado como curativo. O hidrogel de PVP, produzido pela irradiação de sua solução aquosa, tem sido aplicado no tratamento de queimaduras, ulcerações da pele, curativo pós-operatório, etc. 
A tecnologia de produção dos curativos de hidrogel via radiação ionizante possui algumas vantagens em relação ao por processo químico, pois além de ser uma tecnologia mais simples, fácil e limpa (sem resíduos) o produto final é completamente esterilizado (Rosiak, 1991).

Além do hidrogel produzido por Rosiak e colaboradores (1991), existem outros tipos de curativo de hidrogel comercializados como o Vigilon® e Kik gel®. Estes também são esterilizados utilizando a técnica de irradiação (Razzak et al., 2001).

Os hidrogéis também têm sido utilizados amplamente no desenvolvimento de sistema de liberação controlada de fármacos, podendo liberálo de acordo com os estímulos do ambiente, devido a uma mudança de $\mathrm{pH}$ ou de temperatura, por exemplo. Esta classe de hidrogéis sensíveis a estímulos, também é chamada de hidrogéis inteligentes. Hidrogéis de poliacrilameda e quitosana sensíveis a variação de pH (Bonina et al., 2004) e hidrogéis de gelatina e dextrano sensíveis a estímulos duplos (Kurissawa \& Yui, 1998) são alguns exemplos.

\subsubsection{Poli(vinil álcool)}

O poli(vinil álcool) (PVA) é produzido pela hidrólise controlada do poli(vinil acetato). São produzidos PVA de massa molar variável e com diferentes graus de hidrólise, sendo que este irá determinar a solubilidade em água do polímero resultante (Ulrich, 1982).

A descoberta do PVA (FIG. 6) foi em 1924 quando Herrman e Haehnel adicionaram álcali em uma solução de poli(vinil acetato) e obtiveram o poli(vinil álcool), mas foi em 1927 que foi realizado a sua primeira publicação científica (Marten, 1989).

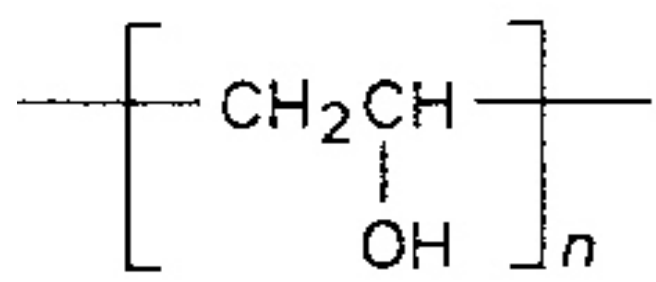

FIGURA 6. Poli(vinil álcool) 
Os filmes de PVA possuem uma excelente resistência a ruptura e abrasão. As propriedades mecânicas deste polímero dependem do grau de hidrólise, massa molar e umidade relativa (Marten, 1989).

O PVA é solúvel em solventes hidrofílicos e altamente polares, como a água. A viscosidade das soluções de PVA é dependente principalmente da massa molar, concentração, grau de hidrólise e temperatura. Materiais com alto grau de hidrólise têm uma maior viscosidade e podem até formar gel (Marten, 1989).

A excelente resistência química e propriedades físicas do PVA fazem com que ele tenha um amplo uso industrial. Ele é muito utilizado na produção de poli(vinil butiral), em fibras, adesivos, papel, etc. (Marten, 1989).

\subsubsection{Poli(N-vinil-2-pirrolidona)}

Polivinilamidas são polímeros anfotéricos, altamente polares, que estão sendo estudados desde 1930. Os polímeros derivados de estruturas cíclicas são os mais importantes, como o poli( $\mathrm{N}$-vinil-2-pirrolidona), também chamado de polivinilpirrolidona, povidone ou PVP (Barabas, 1989).

O PVP (FIG. 7) é produzido pela polimerização do N-vinil-pirrolidona iniciada por um radical livre. Ele é utilizado em formulações cosméticas, na indústria têxtil, em adesivos, etc (Ulrich, 1982).

Este polímero apresenta uma combinação de propriedades, incluindo solubilidade em água e em solventes orgânicos, baixa toxicidade, boas características para formar filmes e habilidade de aderir inúmeros substratos (Barabas, 1989).

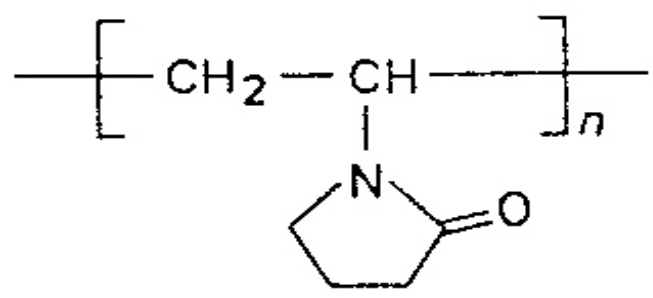

FIGURA 7. Poli(N-vinil-2-pirrolidona) 
Devido sua propriedade adesiva e formadora de filmes é utilizado em sprays de cabelo e adesivos. Já na indústria farmacêutica é utilizado em sistema de liberação de fármacos e na indústria de alimentos para clarificação da cerveja e do vinho. Na Segunda Guerra Mundial o PVP foi usado como espessante de plasma sanguíneo (Barabas, 1989).

O PVP é um pó higroscópico branco ou levemente amarelado. Este polímero consiste de um grupo metileno hidrofóbico e um grupo amina hidrofílico. Como conseqüência deste balanço hidrofóbico-hidrofílico, ele é solúvel em diversos solventes orgânicos e também em água (Barabas, 1989).

Devido às características do vinilpirrolidona, o PVP é quimicamente inerte. O polímero seco pode ser estocado em condições normais sem ocorrer sua decomposição, degradação, ou mudanças estruturais. Em soluções aquosas também podem ser estocadas por um longo período se estocadas adequadamente (Barabas, 1989).

A irradiação da solução aquosa de PVP resulta na formação de macroradicais (na cadeia polimérica) e radicais Hidroxilas $\left(\mathrm{OH}^{\cdot}\right)$ formados durante a radiólise do solvente. A reticulação é resultante da recombinação mútua de macroradicais formados, e como resultado deste processo há formação de ligações covalentes entre estas moléculas. Se a quantidade destas novas ligações for suficientemente grande, aparece no sistema uma fração de gel insolúvel (FIG. 8) (Rosiak \&Ulanski, 1999).

\section{Direto}

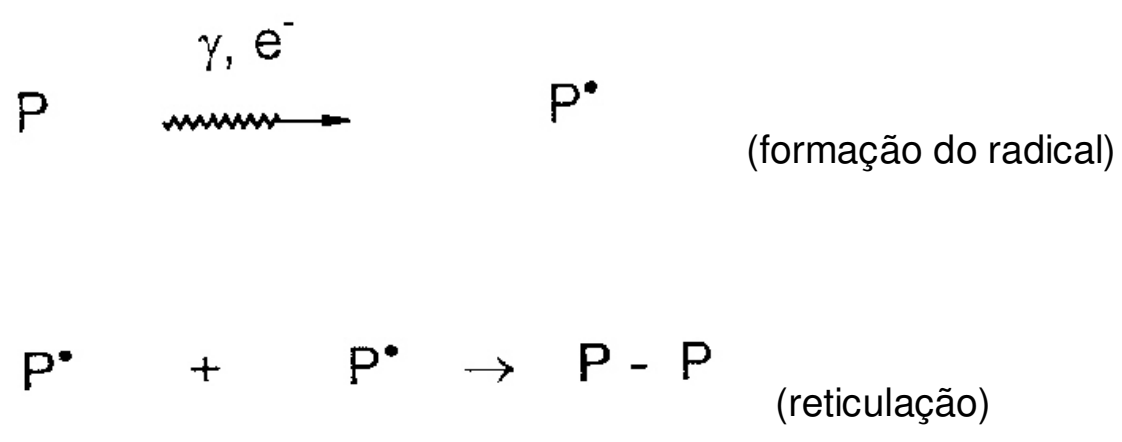




\section{Indireto}

$$
\begin{aligned}
& \mathrm{H}_{2} \mathrm{O} \quad \stackrel{\gamma, e^{-}}{\operatorname{On}} \cdot \mathrm{OH}+\mathrm{H}^{*} \quad \text { (formação do radical) } \\
& \cdot \mathrm{OH}+\mathrm{P} \rightarrow \mathrm{P}^{\cdot}+\mathrm{H}_{2} \mathrm{O} \text { (abstração do } \mathrm{H} \text { do polímero) } \\
& P^{*}+P^{\bullet} \rightarrow P-P \quad \text { (reticulação) }
\end{aligned}
$$

FIGURA 8. Formação do radical polimérico.

\subsection{7 Ágar}

O ágar é uma mistura complexa de polissacarídeos extraídos de espécies de algas vermelhas, conhecidas como agarofitas (espécies de Gelidium, Gracilaria, Pterocladia, Acanthopeltis e Ahnfeltia) (Bridson, 2006). É insolúvel em água e solúvel em água fervente. Quando fervido (não funde abaixo de $85^{\circ} \mathrm{C}$ ) torna-se um líquido límpido e na temperatura entre $32^{\circ} \mathrm{C}$ e $38^{\circ} \mathrm{C}$ ele torna-se sólido para resultar em um gel firme (Farmacopéia Brasileira, 1977).

Agarose é o componente responsável pelas propriedades de geleificação forte do ágar, enquanto a agaropectina é responsável pelas propriedades de viscosidade. A proporção entre agarose e agaropectina em ágar varia de acordo com a alga de origem (Bridson, 2006).

\subsubsection{Poli(etilenoglicol)}

O poli(etilenoglicol) (PEG) (FIG. 9) é um homopolímero termoplástico, obtido pela polimerização catalítica do óxido de etileno (Carey \& Sundberg, 1983). 


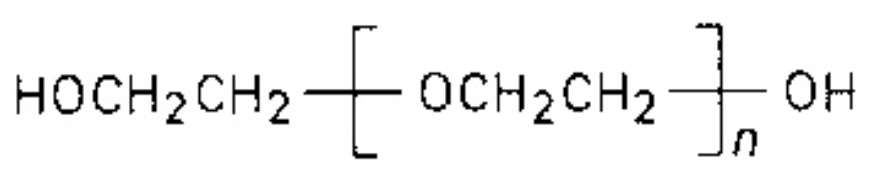

FIGURA 9. Poli(etilenoglicol)

O PEG é miscível em água, possui baixa toxicidade e consegue ser compatível com uma grande variedade de formulações. Possui uma boa estabilidade e pode ser misturado com água (ou outros solventes) para obter uma ampla faixa de viscosidade (Clinton \& Matlock, 1990).

Este polímero é utilizado como surfactante, lubrificante, plastificante (Ulrich, 1982), em formulações cosméticas, soluções de lentes de contato, etc. (Clinton \& Matlock, 1990).

\subsection{Arct'alg $^{\circledR}$}

Observando a vida selvagem na região subártica do Atlântico, pesquisadores verificaram que as algas vermelhas resistiam às baixas temperaturas do inverno extremo, assim como a pouca luminosidade devido os dias serem mais curtos. Estas algas, como a Chondrus crispus, quando submetidas em situação de stress, como no inverno intenso, sintetizam em grande quantidade o dipeptídeo citrulil-arginina, que é utilizado como uma reserva energética (fonte de nitrogênio) para este período do ano (Christophe, 2006). Baseado nesses fatos foi estudado e desenvolvido um extrato natural padronizado desta alga vermelha do mar Ártico, o qual foi registrado como $\operatorname{Arct}^{\prime} \mathrm{Alg}^{\circledR}$. Este extrato é derivado da biomassa da Chondrus crispus que é selecionada sob condições controladas de frio intenso, pouca luminosidade e processo de extração específico que permite a padronização dos principais constituintes (dipeptídeo citrulil-arginina, aminoácido taurina e agentes osmoreguladores) (Exsymol, 2005). 


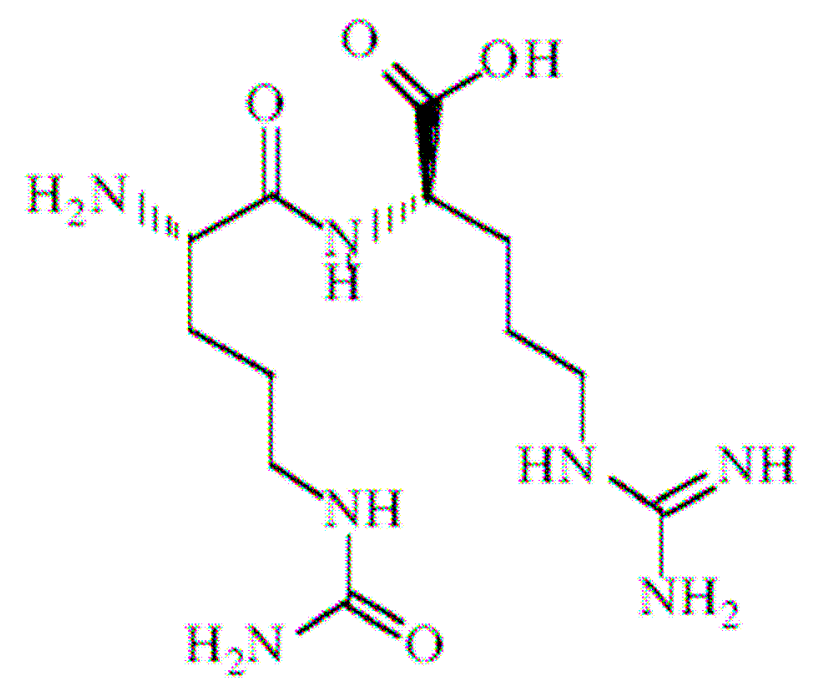

FIGURA 10. Fórmula estrutural do dipeptídeo citrulii-arginina

Arct'$^{\prime} \mathrm{Alg}^{\circledR}$ é um extrato aquoso com cerca de $7,5 \%$ de resíduo seco. Um de seus principais componentes é o dipeptídeo citrulil-arginina (FIG. 10), rico em nitrogênio, representando cerca de $7 \%$ do extrato seco. Outros componentes importantes são: o aminoácido taurina (importante fonte de energia celular), o agente osmoregulador floridosídeo e seus isômeros representando cerca de 13\% do resíduo seco, além de sais minerais como $\mathrm{Ca}, \mathrm{Mg}, \mathrm{K}, \mathrm{Cl}$. Este extrato possui uma excelente ação antioxidante, lipolítica, antiinflamatória e citoestimulante. Devido essas propriedades, O Arct'Alg $^{\circledR}$ pode ser utilizado em produtos cosméticos com ação anti-envelhecimento, anti-celulite e também na no auxílio da cicatrização (Exsymol, 2005).

\subsection{Sistema de liberação de fármacos}

O maior avanço no desenvolvimento de sistemas de liberação de fármacos está na possibilidade de manter a concentração do princípio ativo em um nível terapêutico plasmático por um longo período de tempo, abaixo do nível tóxico e acima do nível mínimo efetivo, como ilustrado na FIG.11 (Heller, 1996). 


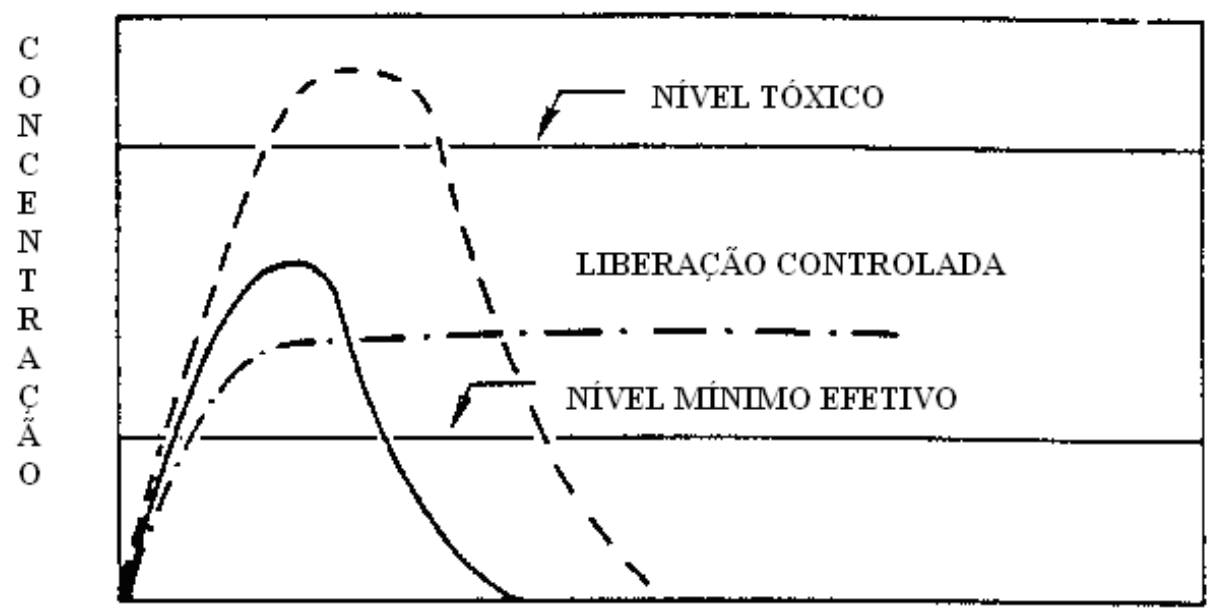

TEMPO

FIGURA 11. Concentração de fármaco absorvido em função do tempo.

$(-)$ dose segura (- - ) dose não segura $\left(-^{\cdot}-{ }^{\cdot}-\right)$ liberação controlada

Um dos materiais mais utilizados como matriz para compor um dispositivo de liberação controlada de medicamentos são os polímeros, principalmente devido à biocompatibilidade, biodegradabilidade, e a possibilidade de se projetar mecanismos ou sistemas diferentes de liberação de drogas (Uhrick et.al., 1999).

Os sistemas poliméricos para a liberação controlada podem ser classificados de acordo com o mecanismo que controla a liberação do agente terapêutico: por difusão, pela penetração de água e quimicamente, como pode ser visto na TAB. 2 (Heller, 1996).

Nos sistemas controlados por difusão existem dois tipos de dispositivos, os monolíticos e os controlados por membrana (dispositivos reservatórios). Em um dispositivo monolítico o fármaco é disperso uniformemente na matriz polimérica e a liberação é controlada por difusão através da matriz. A difusão vai depender da solubilidade do fármaco no polímero, em que ou o princípio ativo vai estar abaixo do limite de solubilidade e dissolvido no polímero ou ele vai estar bem acima do seu limite de solubilidade disperso na matriz (Heller, 1996). Outro fator que interfere na difusão em dispositivos monolíticos é o tamanho do poro. Em hidrogéis, a difusão ocorre através dos poros, em que o fármaco se move por meio das regiões que estão preenchidas com água (Gehrke \& Leee, 1990). 
Nos dispositivos reservatórios o fármaco está contido em um compartimento envolto por uma membrana polimérica que pode ou não ser porosa e que controla a difusão da droga para o meio externo. Um exemplo deste tipo de dispositivo são os contraceptivos transdérmicos (Heller, 1996).

No mecanismo controlado pela penetração de água, a taxa de liberação do fármaco é controlada pela taxa de penetração de água no dispositivo, sendo dois tipos de sistema: o osmótico e o por intumescimento. Nos dispositivos do tipo bomba osmótica o agente osmótico está contido dentro de uma câmara rígida e separado do fármaco por uma partição móvel, sendo que um dos lados do compartimento rígido é uma membrana semipermeável. Quando o dispositivo é imerso em meio aquoso, a água penetra no dispositivo através da membrana aumentando o volume do compartimento osmótico que por conseqüência exerce uma pressão sobre a parte móvel fazendo com que o fármaco saia por meio de um orifício. Nos dispositivos controlados por intumescimento o princípio ativo é disperso uniformemente em uma matriz hidrofílica reticulada, no estado sólido seco. Esta matriz, quando em contato com um meio aquoso, se expande e o fármaco se difunde para fora do polímero (Heller, 1996).

No mecanismo de liberação controlado quimicamente o fármaco é liberado devido à degradação do polímero. Essa degradação pode ocorrer por enzimas, por reações químicas ou pela água. Neste mecanismo existem dois tipos de sistema: monolíticos e de cadeias pendentes. No sistema monolítico o fármaco é disperso uniformemente em um polímero biodegradável, em que sua liberação pode ser controlada pela difusão ou pela degradação ou ainda pela combinação dos dois (Heller, 1996). Nos sistemas de cadeias pendentes o princípio ativo é ligado covalentemente à cadeia de um polímero biodegradável, sendo que sua liberação ocorre com o rompimento das ligações entre o polímero e o fármaco (Heller, 1996). 
TABELA 2. Classificação dos Sistemas de Liberação Controlada.

TIPOS DE SISTEMA

MECANISMO DE LIBERAÇÃO

\section{Controlado pela Difusão}

Dispositivos reservatórios

Difusão através da membrana.

Dispositivos monolíticos

Difusão através do corpo do polímero.

\section{Controlado pela Penetração de Água}

Sistema osmótico

Transporte osmótico da água por meio de uma membrana semipermeável.

Sistema por intumescimento

Penetração de água em um polímero seco.

\section{Controlado Quimicamente}

Sistemas monolíticos

Por erosão ou pela combinação de erosão com difusão.

Sistemas de cadeias laterais (enxertos) Combinação entre a hidrólise do grupo pendente e a difusão do corpo do polímero.

Em sistemas de liberação de fármacos, o termo "hidrogel" é reservado para materiais poliméricos que conseguem absorver quantidades significantes de água (mais que $20 \%$ do seu peso seco) enquanto mantém sua estrutura tridimensional (Gehrke \&Lee, 1990).

Os dispositivos de hidrogel possuem uma relevante importância em sistemas de liberação, pois além de possibilitar o controle da liberação do fármaco, eles aumentam a estabilidade de princípios ativos instáveis por protegêlos do meio externo (Gehrke \&Lee, 1990).

Em relação à incorporação de princípios ativos em hidrogéis, destacam-se dois métodos gerais. $\mathrm{O}$ primeiro método consiste na mistura do 
fármaco com o hidrogel e sua posterior reticulação, fazendo com que o princípio ativo fique preso dentro da matriz. No segundo método, primeiramente, o hidrogel é seco e assim é obtido o dispositivo. Este é mergulhado em uma solução contendo o princípio ativo que é incorporado através da capacidade de intumescimento do hidrogel. Este último método possui algumas vantagens em relação ao primeiro, pois durante o processo de reticulação pode haver uma alteração nas propriedades terapêuticas do princípio ativo (Kim et.al., 1992).

Os hidrogéis devem possuir propriedades fundamentais para que possam ser utilizados como matrizes para compor dispositivos de liberação controlada, sendo elas a biocompatibilidade, permeabilidade e capacidade de intumescimento. Embora esta última propriedade seja a mais importante, é a permeabilidade que faz com que ele possa ser utilizado como um sistema de liberação de fármacos (Gehrke \&Lee, 1990).

Os hidrogéis podem ser impermeáveis, semipermeáveis e totalmente permeáveis em relação a um soluto. Sua permeabilidade pode ser alterada em relação ao tempo ou devido à resposta a um estímulo externo (Gehrke \& Lee, 1990).

A capacidade de intumescimento de um hidrogel também pode ser interferida por um estímulo externo. Assim, nos últimos 30 anos houve um grande interesse no desenvolvimento dos hidrogéis que respondem a estímulos do ambiente. $\mathrm{O}$ uso de hidrogéis inteligentes tem sido proposto, principalmente pelo fato desses géis absorverem uma grande quantidade de água, de possuírem uma natureza elástica similar a de tecidos naturais, por apresentarem biocompatibilidade e, principalmente, por terem a capacidade de controlar a taxa de liberação do fármaco em função de estímulos externos e das condições do meio em que se encontra. Como algumas manifestações de doenças alteram parâmetros do organismo tais como pH, temperatura, concentração de substâncias e etc., esses hidrogéis têm a capacidade de alterar a cinética de liberação do fármaco de acordo com essas mudanças (Langer \& Peppas, 2003). 


\subsection{Citotoxicidade}

A biocompatibilidade pode ser definida como a capacidade de um material funcionar com uma resposta apropriada do hospedeiro em uma aplicação específica (Williams, 1986). Esta resposta apropriada, na maioria dos casos, significa que um sistema vivo na presença de tal material não apresenta resposta adversa. O material não pode ser afetado pelo meio fisiológico, e os tecidos locais e remotos não podem sofrer danos pela presença deste material (Ratner, 1996).

A seleção e avaliação de qualquer material ou dispositivo com intenção de uso em humanos requer um programa estruturado de avaliação. Num processo descrito, deve ser feita uma descrição informada que pesa as vantagens e desvantagens dos vários materiais e escolhas de procedimentos de testes. Para se ter segurança de que o produto final irá realizar/efetuar como desejado e ser seguro para uso humano, o programa deverá incluir uma avaliação biológica (ISO 10993-1, 2003).

A caracterização de materiais biocompatíveis implica na obrigatoriedade do teste de citotoxicidade. A toxicidade de um material pode ser avaliada por testes in vitro, em animais de experimentação, incluindo testes de uso, e por estudos clínicos em seres humanos (ISO 10993-5, 1992).

Os testes in vitro minimizam o uso de animais em pesquisa. Eles são normalmente efetuados como um teste de triagem inicial na primeira fase de avaliação da biocompatibilidade. Eles avaliam os danos causados pelo material às células, fornecendo dados rápidos e de baixo custo. Dentre os vários testes de toxicidade para biomateriais, o teste de citotoxicidade é o mais sensível e sua sensibilidade depende da linhagem celular, do tipo de aplicação dos materiais no teste e da interpretação da resposta celular (ISO 10993-5, 1992).

O teste de citotoxicidade é uma técnica que utiliza cultura celular e determina a lise das células (morte celular), inibição do crescimento celular e outros efeitos, causados pelos dispositivos, materiais e/ou seus extratos (ISO, 1992). Este teste consiste em colocar o material direta ou indiretamente em contato com uma cultura de células de mamíferos, verificando-se as alterações celulares por diferentes mecanismos, entre os quais a incorporação de corantes vitais ou a inibição da formação de colônias celulares (ISO 10993-5, 1992).

Uma das técnicas mais utilizadas para verificar a toxicidade de um material é a de Incorporação do Vermelho Neutro (Ciapetti et. al., 1996). Esta 
técnica foi descrita inicialmente por Finter (1969) e consiste em avaliar a toxicidade por meio da viabilidade celular pela medida da quantidade do corante vermelho neutro incorporado nas células vivas.

\subsection{Citoestimulação de fibroblastos e produção de colágeno}

A principal célula envolvida no processo de regeneração cutânea é o fibroblasto. Com estímulos adequados, durante a reparação tecidual, os fibrócitos (forma inativa da célula) revertem para o estado de fibroblastos (forma ativa da célula) reativando a capacidade de síntese de colágeno e elastina (Junqueira \& Carneiro, 2008).

A síntese de colágeno é um processo bioquímico complexo que ainda não é totalmente conhecido. Os fibroblastos que se encontram no tecido lesionado, durante o processo de regeneração tecidual, são caracterizados por possuírem uma alta produção de colágeno e sintetizar espontaneamente óxido nítrico (NO), o que não ocorre com os fibroblastos que não estão em locais com lesão (Witte et al., 2002).

O NO é produzido em condições inflamatórias e constitui um importante mediador em diversos processos biológicos. Ele é produzido a partir da L-arginina por uma reação mediada pela enzima NO-sintetase (Dusse, et. al., 2003). Esta enzima possui três isoformas, sendo uma delas a NO-sintetase induzível (iNOS) em que sua expressão está diretamente relacionada a processos inflamatórios na pele. A expressão da iNOS não está restrita somente em células do sistema imune como os macrófagos, ela também é expressa em fibroblastos. (Frank et. al., 2002).

A L-arginina é produzida em situações de stress como traumas, ferimento, queimadura, etc. Este aminoácido pode ser metabolizado via NOsintetase produzindo NO ou via arginase produzindo ornitina e uréia (Witte et al., 2002).

A ornitina é precursora das poliaminas e prolinas (Lehninger, 1995). As poliaminas são bases orgânicas alifáticas, pertencentes ao grupo das aminas bioativas, são encontradas em quase todas as células e desempenham diversas atividades biológicas (Lima \& Glória, 1999). Já a prolina é essencial para a formação da fibra colágena devido ser a precursora do colágeno tipo III (Giménez et. al., 2005). 
As poliaminas são essenciais para a citoestimulação celular, ou seja, a proliferação das células fibroblásticas (Witte et al., 2002), devido estarem envolvidas em quase todas as etapas de síntese do DNA, RNA e proteínas. Sendo assim, as poliaminas são indispensáveis as células vivas por estarem diretamente envolvidas com o crescimento e renovação celular (Bardócz, 1995) e principalmente em tecidos com alta demanda celular como na cicatrização de feridas (Kalac \& Krausová, 2005), para que haja um maior número de células fibroblásticas e uma maior produção de colágeno. 


\section{MATERIAIS E MÉTODOS}

\subsection{MATERIAIS}

\subsubsection{Matéria prima utilizada para síntese das matrizes poliméricas}

Poli(N-vinil-pirrolidona) (PVP) K 90, Kollidon® 90F, massa molar média 1000000 - 1500000 proveniente da BASF, poli(etileno glicol) (PEG 300) da Oxiteno, ágar tipo técnico ํㅜ 3 da Oxoid e poli(vinil álcool) (PVA), Celvol® E47/88, grau de hidrólise $87-89 \%$, ponto de fusão de $180^{\circ} \mathrm{C}$, temperatura de transição vítrea de $58^{\circ} \mathrm{C}$, proveniente da Dermet Agekem.

\subsubsection{Princípio ativo}

Arct'Alg $^{\circledR}$ é um extrato de algas de coloração amarela fornecido pela Exymol. Possui cerca de 7,5\% de resíduo seco, sendo cerca de 7\% de dipeptídeo citrulil-arginina, $0,15 \%$ de aminoácido taurina, $0,9 \%$ de floridosídeo, $0,14 \%$ de metil parabeno sódico e sais minerais.

\subsection{MÉTODOS}

\subsubsection{Obtenção das matrizes de hidrogel}

Foram utilizadas duas formulações para a obtenção das matrizes de hidrogel. Os componentes e suas concentrações estão descritos na TAB. 3. 
TABELA 3. Descrição da formulação das membranas de PVP e PVA.

\begin{tabular}{c|c|c}
\hline MATRIZ & COMPOSIÇÃO & CONCENTRAÇÃO (\%) \\
\hline PVP & PVP K90 & 6,0 \\
\hline & PEG 300 & 1,5 \\
\hline & ÁGAR & 0,5 \\
\hline \hline & ÁGUA DESTILADA & 92,0 \\
\hline \hline PVA & & 8 \\
\hline & PVA & 1 \\
\hline & ÁGAR & 91 \\
\hline
\end{tabular}

Para síntese do hidrogel de PVP foram misturados primeiramente o PVP K90, o PEG 300 e a água destilada, deixando durante 24h em temperatura ambiente. Após este período a mistura foi aquecida e adicionou-se o ágar, mantendo-se em aquecimento até a completa dissolução dos componentes. $O$ hidrogel de PVA foi sintetizado a partir da mistura de PVA e água destilada com aquecimento até a dissolução do PVA. Posteriormente foi adicionado o ágar e manteve-se o aquecimento até dissolução total dos componentes.

As membranas de hidrogel foram preparadas vertendo-se $5 \mathrm{~mL}$ da solução resfriada a aproximadamente $40^{\circ} \mathrm{C}$ em moldes circulares de $5 \mathrm{~cm}$ de diâmetro e 0,2 cm de espessura, as quais, após resfriamento, foram seladas, embaladas adequadamente e enviadas para irradiação em uma fonte de raios gama de Co-60. As membranas de PVP foram irradiadas na dose de $25 \mathrm{kGy}$ e as membranas de PVA na dose de $20 \mathrm{kGy}$.

\subsubsection{Caracterização da matriz de hidrogel}

As matrizes de hidrogel de PVP e PVA foram submetidas aos seguintes ensaios:

\subsubsection{Fração Gel}

As amostras de membranas de hidrogel foram secas em estufa na temperatura de $60^{\circ} \mathrm{C}$ até peso constante. Após a secagem, cada amostra com cerca de $0,15 \mathrm{~g}$ cada, em triplicata, foi acondicionada em saquinho de tecido non 
woven e colocadas para remoção da fração solúvel, por 36h, no extrator Soxhlet (FIG. 12), utilizando como solvente a água. Decorrido este tempo as amostras foram novamente secas em estufa na temperatura de $60^{\circ} \mathrm{C}$ até atingirem peso constante.

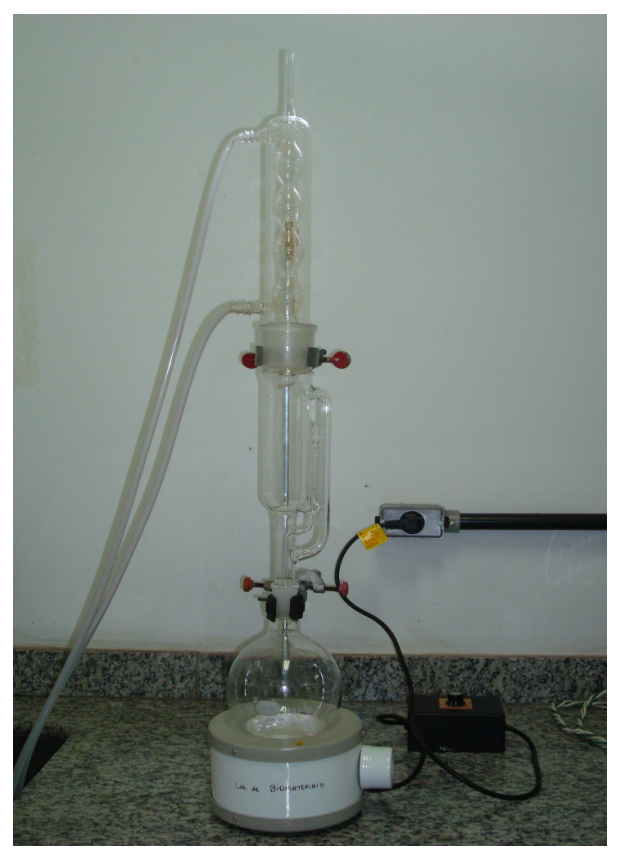

FIGURA 12. Extrator Soxhlet

O cálculo da fração gel foi realizado pelas Equações 1 e 2 de acordo com a norma ASTM D 2765 (ASTM, 2001).

$\mathrm{F}_{\mathrm{s}}=(\mathrm{mi}-\mathrm{mf}) / \mathrm{mi} \times 100$

$F_{G}=100 \%-F_{s}$

Onde: $\mathrm{m} i=$ massa inicial da amostra

$m f=$ massa de gel seco

$\mathrm{F}_{\mathrm{s}}=$ fração solúvel

$F_{G}=$ fração gel

\subsubsection{Intumescimento}

As amostras de membranas de hidrogel foram secas em estufa na temperatura de $60^{\circ} \mathrm{C}$ até peso constante. Cada amostra seca, em triplicata, com 
cerca de $0,15 \mathrm{~g}$ foi colocada em frasco contendo $20 \mathrm{~mL}$ de tampão fosfato salina (PBS) $0,1 \mathrm{M} \mathrm{pH}=5,0$ e durante um período de 24 horas, foi verificada a massa a cada hora durante as primeiras 6 horas do ensaio e após 24 horas.

O grau de intumescimento foi calculado utilizando a Equação 3 de acordo com a norma ASTM D 570 (ASTM, 1998).

$1 \%=(m f-m i) / m i \times 100$

Onde: $1 \%$ = grau de intumescimento em porcentagem

$m f=$ massa final em gramas

$m i=$ massa inicial em gramas

\subsubsection{Propriedades Mecânicas}

As propriedades mecânicas das matrizes de hidrogel foram avaliadas pelo ensaio de tração utilizando-se o texturômetro, modelo TA-TX2i com célula de carga $25 \mathrm{Kg}$, da marca Stable Micro System (FIG 13).

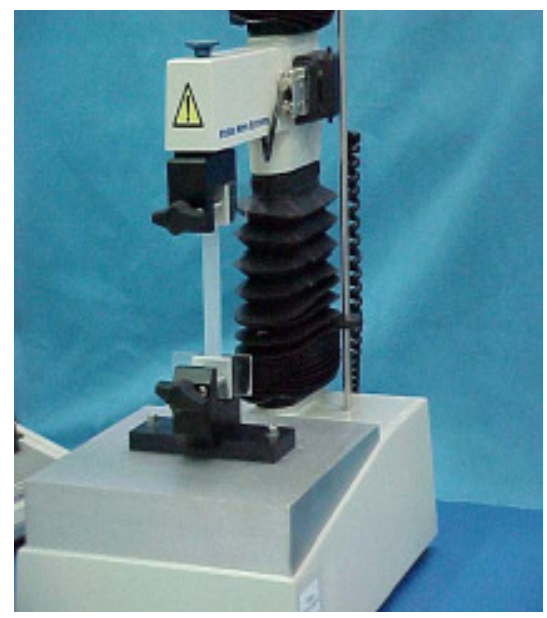

FIGURA 13. Texturômetro, modelo TA-TX2i da Stable Micro System

Foram utilizados corpos de prova retangulares $(2,4 \times 10 \mathrm{~cm})$ fixados em probes roller grips (modelo A/TGT). No ensaio as amostras foram tracionadas a uma velocidade de $0,8 \mathrm{~mm} / \mathrm{s}$, partindo-se de uma distância inicial (lo) de $60 \mathrm{~mm}$, até a ruptura. Este ensaio seguiu a norma ASTM D882-95 (ASTM,1995) e 
metodologia encontrada na literatura (Carvalho e Grosso, 2006) com algumas alterações.

\subsubsection{Citotoxicidade}

O ensaio in vitro de citotoxicidade das matrizes de hidrogel foi realizado utilizando-se a técnica de Incorporação do Vermelho Neutro seguindo normas internacionais (ISO 10993-1, 10993-5 1992) e metodologia publicada anteriormente (Rogero, et. al., 2003). Os extratos das amostras das membranas de hidrogel e do controle negativo foram preparados pela imersão dos mesmos em meio mínimo de Eagle (MEM) e incubados em estufa durante $24 \mathrm{~h}$ a $37^{\circ} \mathrm{C}$. Foi utilizado $1 / 8$ de cada membrana de hidrogel, equivalente a $4,5 \mathrm{~cm}^{2}$ em $9 \mathrm{~mL}$ de MEM, ou seja, $0,5 \mathrm{~cm}^{2} / \mathrm{mL}$. Como controle negativo foi utilizado pellets de PVC (policloreto de vinila) atóxico $\left(1 \mathrm{~cm}^{2} / \mathrm{mL}\right)$ e como controle positivo solução de fenol $0,02 \%$. Após este período, foram feitas diluições seriadas $(100,50,25,12,5$ e $6,25 \%$ ) dos extratos obtidos das amostras e do controle negativo assim como da solução de fenol. Em seguida, $200 \mu \mathrm{L}$ de cada diluição dos extratos e dos controles, em triplicata, foram colocados em contato com uma cultura de células de tecido conectivo de camundongo, a linhagem NCTC clone 929 do ATCC (American Type Culture Collection), cultivadas em microplaca de 96 poços (FIG. 14). A microplaca preparada foi colocada a $37^{\circ} \mathrm{C}$ por $24 \mathrm{~h}$ em estufa incubadora de $\mathrm{CO}_{2}$, modelo $\mathrm{CB} 150$, marca Binder, com atmosfera úmida e $5 \%$ de $\mathrm{CO}_{2}$. O cultivo das células e a distribuição da suspensão celular na microplaca foram realizados na Seção de Culturas Celulares do Instituto Adolfo Lutz.

Esta primeira etapa do ensaio foi realizada em capela de fluxo laminar utilizando técnicas assépticas e todo material estéril.

Após 24h, a microplaca foi retirada da estufa e os extratos foram substituídos por $200 \mu \mathrm{L}$ de solução do corante vermelho neutro e incubada novamente a $37^{\circ} \mathrm{C}$ por $3 \mathrm{~h}$ para incorporação do corante nas células. Decorrido este período o corante foi desprezado e a microplaca lavada com solução tampão fosfato $\mathrm{pH} 7,4$ e posteriormente com solução de lavagem ( $1 \%$ de $\mathrm{CaCl}_{2} 10 \%$ em solução de formaldeído $0,5 \%$ ). Após a lavagem os poços da microplaca foram preenchidos com $200 \mu \mathrm{L}$ de solução de extração (50\% de ácido acético $2 \%$ e etanol $50 \%$ ) para a lise das células vivas e liberação do corante. 


\begin{tabular}{|c|c|c|c|c|c|c|c|c|c|c|c|c|}
\hline & 1 & 2 & 3 & 4 & 5 & 6 & 7 & 8 & 9 & 10 & 11 & 12 \\
\hline A & $100 \%$ & $100 \%$ & $100 \%$ & $100 \%$ & $100 \%$ & $100 \%$ & $100 \%$ & $100 \%$ & $100 \%$ & $100 \%$ & $100 \%$ & $100 \%$ \\
\hline B & $50 \%$ & $50 \%$ & $50 \%$ & $50 \%$ & $50 \%$ & $50 \%$ & $50 \%$ & $50 \%$ & $50 \%$ & $50 \%$ & $50 \%$ & $50 \%$ \\
\hline C & $25 \%$ & $25 \%$ & $25 \%$ & $25 \%$ & $25 \%$ & $25 \%$ & $25 \%$ & $25 \%$ & $25 \%$ & $25 \%$ & $25 \%$ & $25 \%$ \\
\hline D & $12,5 \%$ & $12,5 \%$ & $12,5 \%$ & $12,5 \%$ & $12,5 \%$ & $12,5 \%$ & $12,5 \%$ & $12,5 \%$ & $12,5 \%$ & $12,5 \%$ & $12,5 \%$ & $12,5 \%$ \\
\hline E & $6,25 \%$ & $6,25 \%$ & $6,25 \%$ & $6,25 \%$ & $6,25 \%$ & $6,25 \%$ & $6,25 \%$ & $6,25 \%$ & $6,25 \%$ & $6,25 \%$ & $6,25 \%$ & $6,25 \%$ \\
\hline F & MEM & MEM & $100 \%$ & $50 \%$ & $25 \%$ & $12,5 \%$ & $6,25 \%$ & $100 \%$ & $50 \%$ & $25 \%$ & $12,5 \%$ & $6,25 \%$ \\
\hline G & MEM & MEM & $100 \%$ & $50 \%$ & $25 \%$ & $12,5 \%$ & $6,25 \%$ & $100 \%$ & $50 \%$ & $25 \%$ & $12,5 \%$ & $6,25 \%$ \\
\hline H & MEM & MEM & $100 \%$ & $50 \%$ & $25 \%$ & $12,5 \%$ & $6,25 \%$ & $100 \%$ & $50 \%$ & $25 \%$ & $12,5 \%$ & $6,25 \%$ \\
\hline
\end{tabular}

FIGURA 14. Esquema da distribuição dos extratos das amostras e controle na microplaca. Legenda:

Amostra 1

Amostra 2

Amostra 3

Amostra 4

Controle de células

Controle negativo

Controle positivo

A leitura da microplaca foi realizada em espectrofotômetro, leitora ELISA modelo Sunrise da Tecan, em $540 \mathrm{~nm}$. Com as densidades óticas (DO) obtidas foram feitos cálculos da porcentagem de viabilidade celular tomando-se como referência a DO do controle de células no ensaio.

O potencial tóxico foi determinado quantitativamente pelo índice de citotoxicidade $\left(\mathrm{IC}_{50 \%}\right)$ encontrado no gráfico obtido. O IC $\mathrm{IC}_{50 \%}$ é a concentração de extrato que provoca a morte de metade da população celular do ensaio.

\subsubsection{Preparo do dispositivo de hidrogel}

Primeiramente foi feito um estudo do princípio ativo para avaliar sua atividade citoestimulante e verificar a sua integridade frente à radiação ionizante.

\subsubsection{Citoestimulação}

A atividade citoestimulante do Arct'Alg ${ }^{\circledR}$ foi verificada no ensaio in vitro de citoestimulação utilizando o método de incorporação do corante vermelho neutro de acordo com a metodologia encontrada na literatura (Christophe, 2006). 
Essa metodologia requereu como primeira etapa a verificação da faixa de concentração do princípio ativo $\operatorname{Arct}^{\prime} A{ }^{\circledR}$ a ser utilizada, em que foi estabelecida no ensaio de citotoxicidade.

Posteriormente, foram realizados vários ensaios de citoestimulação (cerca de 18) para padronização da quantidade ideal de células, tipo de meio de cultura com a quantidade adequada de Soro Fetal Bovino (SFB), tempo de incubação e concentração do princípio ativo.

As concentrações de princípio ativo utilizadas nestes ensaios foram de 2, 1, 0,5 e 0,25\%. Estas concentrações foram determinadas de acordo com o ensaio de citotoxicidade do Arct' $^{\prime} \mathrm{Alg}^{\circledR}$ realizado previamente, em que o resultado obtido mostrou que as concentrações abaixo de $2,5 \%$ do princípio ativo eram atóxicas.

Em seguida, foram realizados alguns ensaios com células fibroblásticas de pele de coelho, linhagem celular FPC - IAL para padronizar o número de células $/ \mathrm{mL}$ que iria conter na suspensão celular que seria utilizada para preparar a microplaca. No primeiro ensaio foi utilizada uma microplaca que foi preparada com uma suspensão de 200.000 células $/ \mathrm{mL}$, sendo que duas fileiras da microplaca foram cultivadas com MEM e L-15 (v/v) mais 5\% SFB como controle do ensaio; outras duas fileiras com MEM e L-15 (v/v) mais 10\% SFB, meio que proporciona condição nutricional total e nas outras fileiras foi colocado as diferentes concentrações do Arct'Alg $^{\circledR}$ com o MEM e L-15 (v/v) mais 5\% SFB. Neste ensaio a microplaca foi incubada durante $24 \mathrm{~h}$ e depois feito a leitura da DO. O resultado obtido foi que a viabilidade celular deste ensaio, em todas as condições nutricionais das células, foi semelhante e elevada, não havendo diferença significativa entre as células que se encontravam em condição restrita de nutrição com as que estavam com o princípio ativo ou em condição de nutrição total (Apêndice A). Portanto decidiu-se diminuir a quantidade do número de células $/ \mathrm{mL}$ para o próximo ensaio.

Outros 4 ensaios foram realizados, iguais ao descrito anteriormente, onde foi alterado somente o número de células $/ \mathrm{mL}$. Foram testadas suspensões de 180.000 células $/ \mathrm{mL}, 150.000$ células $/ \mathrm{mL}$ e 100.000 células $/ \mathrm{mL}$, sendo este último realizado em duplicata. $O$ melhor resultado encontrado foi com a suspensão celular de 100.000 células $/ \mathrm{mL}$, mas mesmo assim não foi muito 
satisfatório devido a viabilidade celular do controle do ensaio ainda estar elevada (Apêndice B).

Após a padronização do número de células $/ \mathrm{mL}$ foram realizados os ensaios para padronizar a concentração adequada de SFB e também verificar se o L-15 interferia no crescimento celular. Para tanto, foi realizado um ensaio utilizando uma microplaca preparada com uma suspensão de 100.000 células $/ \mathrm{mL}$ cultivadas com MEM e as concentrações de 15, 10, 5 e $2 \%$ de SFB. A microplaca foi incubada durante $24 \mathrm{~h}$ e após término do ensaio feito a leitura da DO (Apêndice C). Neste ensaio pode-se observar que houve um aumento da viabilidade celular nas concentrações de 10 e 15\% de SFB, mas não houve uma diferença significativa do crescimento celular entre essas concentrações. Já as células que estavam em contato com 5\% de SFB apresentaram um pequeno crescimento e as que estavam com $2 \%$ mantiveram-se sem crescimento. Este mesmo ensaio foi repetido utilizando MEM e L-15 (v/v) junto com o SFB para verificar se não havia alteração no crescimento das células (Apêndice D). O resultado obtido neste ensaio foi semelhante ao obtido quando se utilizou somente o soro fetal bovino. Sendo assim, foi determinado utilizar o meio de cultura MEM e L-15 (v/v) com 2\% SFB para o controle do ensaio de citoestimulação e o MEM e L-15 (v/v) com 10\% SFB como o meio de cultura com condição total de nutrição.

Tendo a padronização da suspensão celular de 100.000 céls/mL e das concentrações de SFB (2 e 10\%), foram realizados os ensaios com o Arct'Alg $^{\circledR}$. No primeiro ensaio foi utilizada apenas uma microplaca, contendo o meio de condição total de nutrição (MEM e L-15 (v/v) com 10\% SFB), o meio com déficit de nutrição (MEM e L-15 (v/v) com 2\% SFB), ou seja, o controle do ensaio, e o princípio ativo em diferentes concentrações (2;1;0,5 e 0,25\%) sendo esta diluição seriada feita em meio MEM e L-15 (v/v) mais 2\% SFB. A microplaca foi incubada durante $24 \mathrm{~h}$ e após finalizar o ensaio feito a leitura da DO (Apêndice E). Neste ensaio, ainda não foi possível observar um crescimento significativo das células em contato com o princípio ativo. Tentou-se, portanto aumentar a incubação da microplaca para $48 \mathrm{~h}$.

No ensaio realizado com $48 \mathrm{~h}$ de incubação o resultado mostrou que houve aumento no número das células que estavam em contato com o $\operatorname{Arct}^{\prime} \mathrm{Alg}^{\circledR}$. Este ensaio foi repetido, mas o resultado não foi reprodutível (Apêndice F). Portanto, decidiu-se trabalhar com microplacas separadas, ou seja, uma 
microplaca para MEM e L-15 (v/v) mais 2\% SFB; outra para MEM e L-15 (v/v) mais $10 \%$ SFB e outra para o princípio ativo. Foram realizados mais 3 ensaios utilizando esta metodologia e os mesmos apresentaram reprodutibilidade. Este resultado está apresentado no item 5.4 em resultados e discussão.

Portanto, de acordo com a metodologia desenvolvida, em cada ensaio foram utilizadas 3 microplacas com linhagem celular FPC - IAL onde foram distribuídos $200 \mu \mathrm{L}$ de uma suspensão de 100.000 células $/ \mathrm{mL}$. A cultura celular e a preparação da microplaca foi realizada na Seção de Culturas Celulares do Instituto Adolfo Lutz. Na microplaca 1 - placa controle do ensaio - as células ficaram em déficit nutricional parcial (MEM e L-15 (v/v) contendo 2\% SFB); microplaca 2 - as células em condição nutricional total (MEM e L-15 (v/v) contendo $10 \%$ SFB); microplaca 3 - as células em contato com o princípio ativo em diferentes concentrações (2; $1 ; 0,5$ e 0,25\%) sendo esta diluição seriada feita em meio MEM e L-15 (v/v) contendo 2\% SFB. A distribuição das diferentes concentrações do princípio ativo está ilustrada na FIG. 15.

\begin{tabular}{|c|c|c|c|c|c|c|c|c|c|c|c|c|}
\hline & 1 & 2 & 3 & 4 & 5 & 6 & 7 & 8 & 9 & 10 & 11 & 12 \\
\hline $\mathrm{A}$ & $2 \%$ & $2 \%$ & $2 \%$ & $1 \%$ & $1 \%$ & $1 \%$ & $0,5 \%$ & $0,5 \%$ & $0,5 \%$ & $0,25 \%$ & $0,25 \%$ & $0,25 \%$ \\
\hline $\mathrm{B}$ & $2 \%$ & $2 \%$ & $2 \%$ & $1 \%$ & $1 \%$ & $1 \%$ & $0,5 \%$ & $0,5 \%$ & $0,5 \%$ & $0,25 \%$ & $0,25 \%$ & $0,25 \%$ \\
\hline $\mathrm{C}$ & $2 \%$ & $2 \%$ & $2 \%$ & $1 \%$ & $1 \%$ & $1 \%$ & $0,5 \%$ & $0,5 \%$ & $0,5 \%$ & $0,25 \%$ & $0,25 \%$ & $0,25 \%$ \\
\hline $\mathrm{D}$ & $2 \%$ & $2 \%$ & $2 \%$ & $1 \%$ & $1 \%$ & $1 \%$ & $0,5 \%$ & $0,5 \%$ & $0,5 \%$ & $0,25 \%$ & $0,25 \%$ & $0,25 \%$ \\
\hline $\mathrm{E}$ & $2 \%$ & $2 \%$ & $2 \%$ & $1 \%$ & $1 \%$ & $1 \%$ & $0,5 \%$ & $0,5 \%$ & $0,5 \%$ & $0,25 \%$ & $0,25 \%$ & $0,25 \%$ \\
\hline $\mathrm{F}$ & $2 \%$ & $2 \%$ & $2 \%$ & $1 \%$ & $1 \%$ & $1 \%$ & $0,5 \%$ & $0,5 \%$ & $0,5 \%$ & $0,25 \%$ & $0,25 \%$ & $0,25 \%$ \\
\hline $\mathrm{G}$ & $2 \%$ & $2 \%$ & $2 \%$ & $1 \%$ & $1 \%$ & $1 \%$ & $0,5 \%$ & $0,5 \%$ & $0,5 \%$ & $0,25 \%$ & $0,25 \%$ & $0,25 \%$ \\
\hline $\mathrm{H}$ & $2 \%$ & $2 \%$ & $2 \%$ & $1 \%$ & $1 \%$ & $1 \%$ & $0,5 \%$ & $0,5 \%$ & $0,5 \%$ & $0,25 \%$ & $0,25 \%$ & $0,25 \%$ \\
\hline
\end{tabular}

FIGURA 15. Esquema da distribuição das diferentes concentrações de $\operatorname{Arct}^{\prime} \operatorname{Alg}^{\circledR}$ na microplaca 3. Legenda:
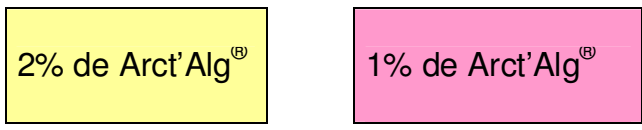

$0,5 \%$ de $\operatorname{Arct}^{\prime} \mathrm{Alg}^{\circledR}$ $0,25 \%$ de Arct'Alg $^{\circledR}$ 
As microplacas foram colocadas a $37^{\circ} \mathrm{C}$ por $48 \mathrm{~h}$ em estufa incubadora de $\mathrm{CO}_{2}$, modelo $\mathrm{CB150}$, marca Binder,com atmosfera úmida e $5 \%$ de $\mathrm{CO}_{2}$. Após este período, a microplaca foi retirada da estufa e os extratos foram substituídos por $200 \mu \mathrm{L}$ de solução do corante vermelho neutro e incubada novamente a $37^{\circ} \mathrm{C}$ por 3h para incorporação do corante nas células. Posteriormente o corante foi desprezado e a microplaca lavada com solução tampão fosfato $\mathrm{pH} \mathrm{7,4} \mathrm{e}$ posteriormente com solução de lavagem (1\% de $\mathrm{CaCl}_{2} \quad 10 \%$ em solução de formaldeído 0,5\%). Após a lavagem os poços da microplaca foram preenchidos com $200 \mu \mathrm{L}$ de solução de extração (50\% de ácido acético $2 \%$ e etanol $50 \%$ ) para a lise das células e liberação do corante.

A citoestimulação foi verificada pelo aumento do número de células, medida pelo aumento da incorporação do vermelho neutro, sendo quantificada em espectrofotômetro, leitora ELISA, modelo Sunrise da Tecan, em 540nm. Com as DO obtidas na leitura da microplaca foram feitos os cálculos do aumento do número de células em relação à microplaca 1, controle de células do ensaio, considerado $100 \%$ de viabilidade celular.

\subsubsection{Estudo do comportamento do dipeptídeo citrulil-arginina irradiado}

Para o preparo do dispositivo de hidrogel, ou seja, a incorporação do $\operatorname{Arct}^{\prime} A^{\circledR}{ }^{\circledR}$ na membrana de PVP e PVA, foi realizado anteriormente um estudo sobre o comportamento do dipeptídeo citrulil-arginina frente à radiação ionizante.

Uma solução padrão de citrulil-arginina foi preparada, em um balão volumétrico de $100 \mathrm{~mL}$, dissolvendo $20 \mathrm{mg}$ de citrulil-arginina em água purificada no sistema Milli-Q. Uma parte desta solução padrão foi irradiada em uma fonte de Co-60 com taxa de dose de 5,72 kGY/h ${ }^{-1}$ na dose de $20 \mathrm{kGy}$. A estabilidade desta solução foi verificada por meio da cromatografia líquida de alta eficiência (HPLC) conforme metodologia descrita pelo fabricante (Exsymol) com algumas modificações. O equipamento utilizado foi um HPLC composto por módulos da Shimadzu (FIG.16) como: desgaseificador de fase móvel, modelo DGU-3A; bomba binária de vazão constante, modelo LC-10Ai; detetor UVvis, modelo SPD10AVi; unidade de aquecimento de coluna, modelo CTO-10 A; injetor automático, modelo SIL-10Ai; módulo de comunicação para operação CBM-10 A e programa para aquisição de dados CLASS-LC10. 


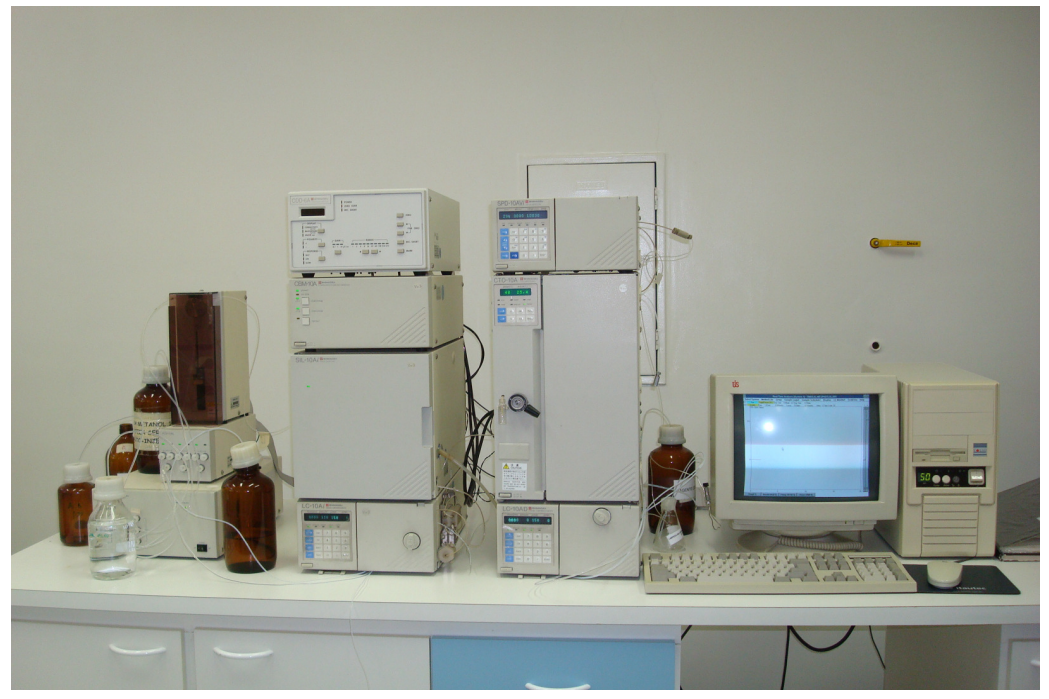

FIGURA 16. Sistema de HPLC da Shimadzu

Foi injetado $5 \mu \mathrm{L}$ da amostra em uma coluna de fase reversa C18 (4 $\mu \mathrm{m} \times 250 \mathrm{~mm} \times 4.6 \mathrm{~mm}$ ) proveniente da Varian, utilizando fluxo de $1 \mathrm{~mL} / \mathrm{min}$ e detecção realizada em $200 \mathrm{~nm}$. A fase móvel utilizada neste ensaio consiste em $3 \%$ de acetonitrila e $97 \%$ de PIC B6 proveniente da Waters em um sistema isocrático.

Pela comparação das áreas de pico do citrulil-arginina nas duas amostras foi verificada a integridade da solução de citrulil arginina irradiada.

\subsubsection{Incorporação do Arct'Alg $^{\circledR}$ na matriz de hidrogel}

A incorporação do Arct'Alg® na matriz de hidrogel de PVP e PVA foi feita logo após a preparação da formulação do hidrogel.

Primeiramente obtiveram-se as formulações de hidrogel de PVP e PVA de acordo com a metodologia descrita no item 4.2.1. Após o resfriamento em aproximadamente $40^{\circ} \mathrm{C}$, foi incorporado $3 \%$ de $\operatorname{Arct} A \mathrm{Alg}{ }^{\circledR}$ em cada uma das formulações e misturado até completa homogeneização.

Foram então preparados os dispositivos de liberação, em forma de membranas, vertendo-se $5 \mathrm{~mL}$ da formulação contendo o princípio ativo em moldes circulares de $5 \mathrm{~cm}$ de diâmetro e $0,15 \mathrm{~cm}$ de profundidade, as quais, foram seladas, embaladas e enviadas para irradiação em uma fonte de raios gama de Co-60 com taxa de dose de 5,72 kGY/h ${ }^{-1}$. Os dispositivos de PVP foram irradiados na dose de 25 kGy e os de PVA na dose de 20 kGy. 


\subsubsection{Cinética de liberação e doseamento do $\operatorname{Arct}^{\prime} \mathbf{A l g}^{\circledR}$}

Para o estudo da cinética de liberação in vitro do dispositivo de liberação de Arct'Alg® foram realizados ensaios de cinética de liberação com: membranas das matrizes de PVP e PVA, dispositivos de PVP e PVA contendo Arct'Alg® e dispositivos de PVP e PVA contendo citrulil-arginina. As membranas de hidrogel foram cortadas ao meio e imersas em $35 \mathrm{~mL}$ de PBS $0,1 \mathrm{M} \mathrm{pH}=5,0$ em frascos de vidro, em triplicata, e colocadas em uma incubadora da Tecnal, modelo TE-420, sob agitação constante a $37^{\circ} \mathrm{C}$. Alíquotas de $1 \mathrm{~mL}$ foram coletadas de 1 em 1 hora durante as primeiras 7 horas do ensaio e uma última após 24 horas. O doseamento do princípio ativo liberado foi realizado em HPLC por meio da injeção de $100 \mu \mathrm{L}$ das amostras coletadas durante o ensaio de liberação em uma coluna de fase reversa $\mathrm{C} 18$ conforme metodologia descrita no item 4.2.3.2.

A quantidade de $\operatorname{Arct}^{\prime} \mathrm{Alg}^{\circledR}$ liberado foi calculado por meio da comparação da área do pico da solução padrão de citrulil arginina com a área do pico de citrulil-arginina presente no Arct'Alg $^{\circledR}$ liberado.

As alíquotas coletadas das membranas controle de PVP e PVA e das de PVP e PVA contendo citrulil-arginina não foram doseadas. Foi realizada apenas uma injeção de cada amostra após 1 hora do ensaio de liberação para que fosse feito a análise comparativa dos picos dos cromatogramas.

\subsubsection{Atividade citoestimulante do Arct' $^{\prime}{ }^{\circledR}{ }^{\circledR}$ liberado}

O Arct'Alg $^{\circledR}$ liberado in vitro foi testado quanto a sua atividade citoestimulante pelo método da incorporação do corante vermelho neutro. As alíquotas utilizadas neste ensaio foram as que apresentaram a maior quantidade liberada, obtida no estudo da cinética de liberação.

Em capela de fluxo laminar as membranas de hidrogel de PVP e PVA contendo $3 \%$ Arct'Alg $^{\circledR}$ cada foram colocadas em frasco estéril com $24 \mathrm{~mL}$ de MEM com L-15 mais $2 \%$ SFB. Estes fracos foram colocados em uma incubadora da Tecnal, modelo TE-420, com agitação constante na temperatura de $37^{\circ} \mathrm{C}$ durante uma hora, para liberação do princípio ativo. Após este período os frascos foram retirados da incubadora e levados a uma capela de fluxo laminar onde o meio de cultura foi transferido para as respectivas microplacas contendo células 
fibroblásticas de pele e coelho, linhagem celular FPC - IAL. As microplacas de 96 poços foram preparadas com uma suspensão de 100.000 células $/ \mathrm{mL}$, tendo sido distribuídas $200 \mu \mathrm{L}$ em cada poço. A cultura celular e preparação das microplacas foram realizadas pelo Instituto Adolfo Lutz .

Foram utilizadas 4 microplacas onde houve substituição do meio de cultura das células fibroblásticas por $200 \mu \mathrm{L}$ de cada tipo de meio, conforme descrito a seguir:

- Microplaca 1: meio com déficit nutricional parcial - MEM e L-15 (v/v) com 2\% SFB, para o controle do ensaio;

- Microplaca 2: meio com condição nutricional total - MEM e L-15 (v/v) com 10\% SFB;

- Microplaca 3 e 4: foi colocado na primeira metade da microplaca o meio com o princípio ativo liberado da membrana de PVP e na outra metade o meio contendo o princípio ativo liberado da membrana de PVA.

As microplacas foram colocadas a $37^{\circ} \mathrm{C}$ por $48 \mathrm{~h}$ em estufa incubadora de $\mathrm{CO}_{2}$, com atmosfera úmida e $5 \%$ de $\mathrm{CO}_{2}$.

A citoestimulação do princípio ativo liberado foi verificada pelo aumento do número de células por meio da incorporação do corante vermelho neutro. A quantificação do corante foi obtida em espectrofotômetro, leitora ELISA, modelo Sunrise da Tecan, em 540nm. O cálculo do aumento do número de células foi feito com base no controle de células do ensaio o qual foi considerado $100 \%$. 


\section{RESULTADOS E DISCUSSÃO}

\subsection{Obtenção das matrizes de hidrogel}

As matrizes de hidrogel de PVP e PVA foram obtidas por meio da radiação ionizante conforme descrito no item $4.2 .1 \mathrm{em}$ materiais e métodos.

O critério para considerar as membranas adequadas ou não para serem submetidas aos ensaios de caracterização foi a formação de um filme homogêneo, transparente e elástico, parâmetros avaliados visualmente e manualmente. Ambas as matrizes formaram um filme homogênio, transparente, com boa adesividade e mostraram uma resistência adequada para a manipulação. A matriz de PVP apresentou uma transparência mais acentuada que a de PVA, como pode ser observado nas FIG. 17 e 18.

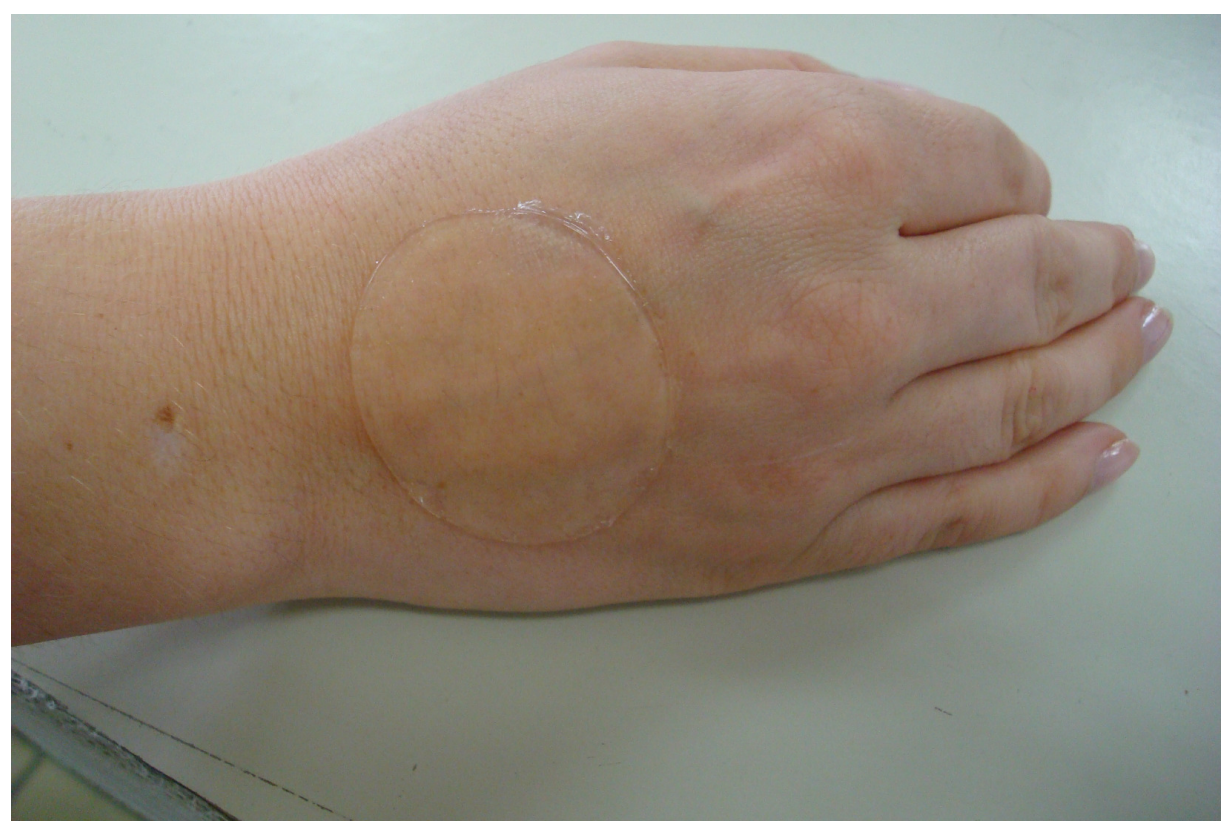

FIGURA 17. Matriz de hidrogel de PVP 


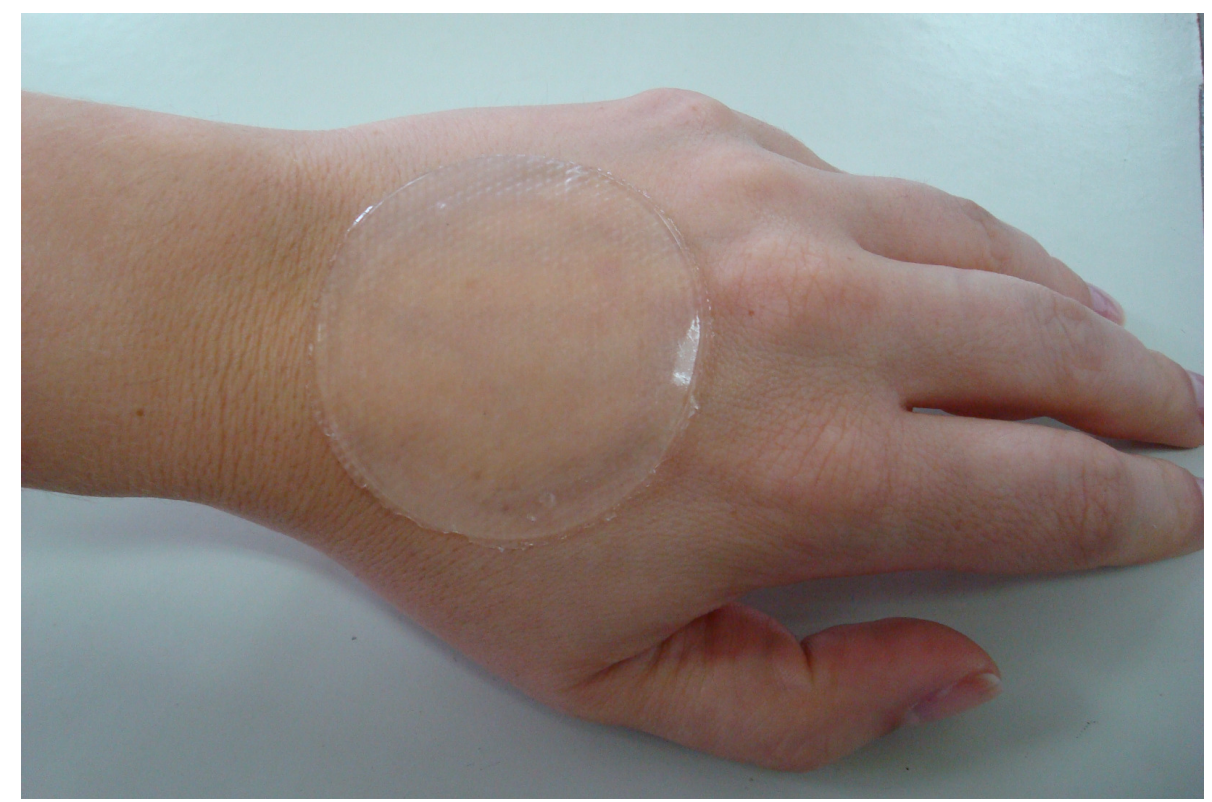

FIGURA 18. Matriz de hidrogel de PVA

\subsection{Caracterização da matriz de hidrogel}

\subsubsection{Fração Gel}

A determinação da fração gel, fração do polímero reticulada, é uma forma eficiente para avaliar a reticulação de matrizes poliméricas. Membranas de PVP e PVA foram preparadas e a fração gel medida segundo o procedimento descrito no item 4.2.2.1 em materiais e métodos. Neste ensaio pode-se observar que se obteve um conteúdo de gel elevado, indicando uma elevada formação de retículos entre as moléculas poliméricas.

Apesar da membrana de PVA apresentar porcentagem de fração gel cerca de $10 \%$ maior que a membrana de PVP, os resultados da TAB. 4 mostram que tanto o PVA quanto o PVP são polímeros capazes de obter um alto grau de reticulação. 
TABELA 4. Resultados do ensaio de fração gel das membranas de PVP e PVA.

\begin{tabular}{cccc}
\hline Membrana & $\mathbf{m i}(\mathbf{g})$ & $\mathbf{m f}(\mathbf{g})$ & \% fração gel \\
\hline \multirow{3}{*}{ PVP } & 0,1433 & 0,1075 & \\
& 0,1490 & 0,1123 & $73,8 \pm 2,4$ \\
& 0,1267 & 0,0901 & \\
\hline \multirow{3}{*}{ PVA } & 0,1309 & 0,1107 & \\
& 0,1492 & 0,1253 & $84,4 \pm 0,3$ \\
\hline
\end{tabular}

Segundo estudo semelhante realizado por Zhao e colaboradores (2003), o hidrogel de PVA associado à quitosana carboximetilada irradiado na dose de 20kGy apresentou porcentagem de fração gel cerca de $88 \%$, sendo este resultado bem próximo ao obtido neste trabalho, o qual foi de aproximadamente $84 \%$.

\subsubsection{Intumescimento}

O intumescimento é definido como a quantidade de água absorvida pelo material polimérico no equilíbrio, quando o mesmo é submerso em água por um período de tempo suficiente para que o sistema atinja volume constante (Flory, 1986). Esta absorção de água modifica significativamente as propriedades dos materiais poliméricos, no caso das membranas hidrofílicas, permite estimar o seu comportamento em sistemas de liberação de fármacos (Sen, 1999).

Foi realizado o ensaio de intumescimento com as membranas de hidrogel de PVP e PVA obtidas conforme descrito no item 4.2.2.2 em materiais e métodos. Os resultados estão apresentados na TAB. 5 e o perfil de intumescimento dos hidrogéis pode ser observado na FIG. 19. Os resultados mostram que tanto o hidrogel de PVP quanto o de PVA possuem uma boa capacidade de intumescimento, sendo que nas primeiras 6h observa-se um intumescimento rápido de ambos os hidrogéis. Pode ser verificado que o hidrogel de PVP apresentou intumescimento maior do que o hidrogel de PVA, sendo esta diferença de $25 \%$ em 24 horas. Esta diferença deverá ser levada em 
consideração na eventual utilização de incorporação de um agente ativo pela capacidade de intumescimento da membrana de hidrogel e também no momento da sua liberação.

Em trabalho publicado na literatura por Ajji e colaboradores (2005) sobre a produção de curativos de hidrogéis de PVP por meio da radiação gama, foi verificado a capacidade de intumescimento dos mesmos utilizando diferentes concentrações de PVP e PEG sendo irradiado na dose de 25 kGy. Neste estudo, o hidrogel de PVP irradiado na dose de 25 kGy apresentou comportamento semelhante ao obtido por Ajji e colaboradores após 24 horas, podendo o mesmo aumentar quase 20 vezes o seu peso inicial.

De acordo com Flory (1986), a absorção de água pela rede (intumescimento) depende do grau e da natureza das reticulações do hidrogel. Esta afirmação pode explicar a diferença na capacidade de intumescimento entre os hidrogéis, pois possivelmente o hidrogel de PVA intumesceu menos devido apresentar um grau de reticulação maior que o hidrogel de PVP. Outra possibilidade, conforme Flory, seria a natureza das reticulações, pois a rede de PVA poderia conter também reticulações físicas.

TABELA 5. Resultados do ensaio de intumescimento dos hidrogéis de PVP e PVA.

\begin{tabular}{ccc}
\hline $\begin{array}{c}\text { TEMPO } \\
(\mathrm{h})\end{array}$ & \multicolumn{2}{c}{ INTUMESCIMENTO (\%) } \\
\hline 1 & $847,58 \pm 16$ & PVA \\
\hline 2 & $1180,38 \pm 18$ & $325,03 \pm 14$ \\
3 & $1355,07 \pm 20$ & $680,88 \pm 13$ \\
4 & $1470,38 \pm 13$ & $839,65 \pm 19$ \\
5 & $1564,70 \pm 16$ & $988,26 \pm 19$ \\
6 & $1593,59 \pm 19$ & $1105,89 \pm 20$ \\
24 & $1658,99 \pm 14$ & $1309,12 \pm 18$ \\
\hline
\end{tabular}




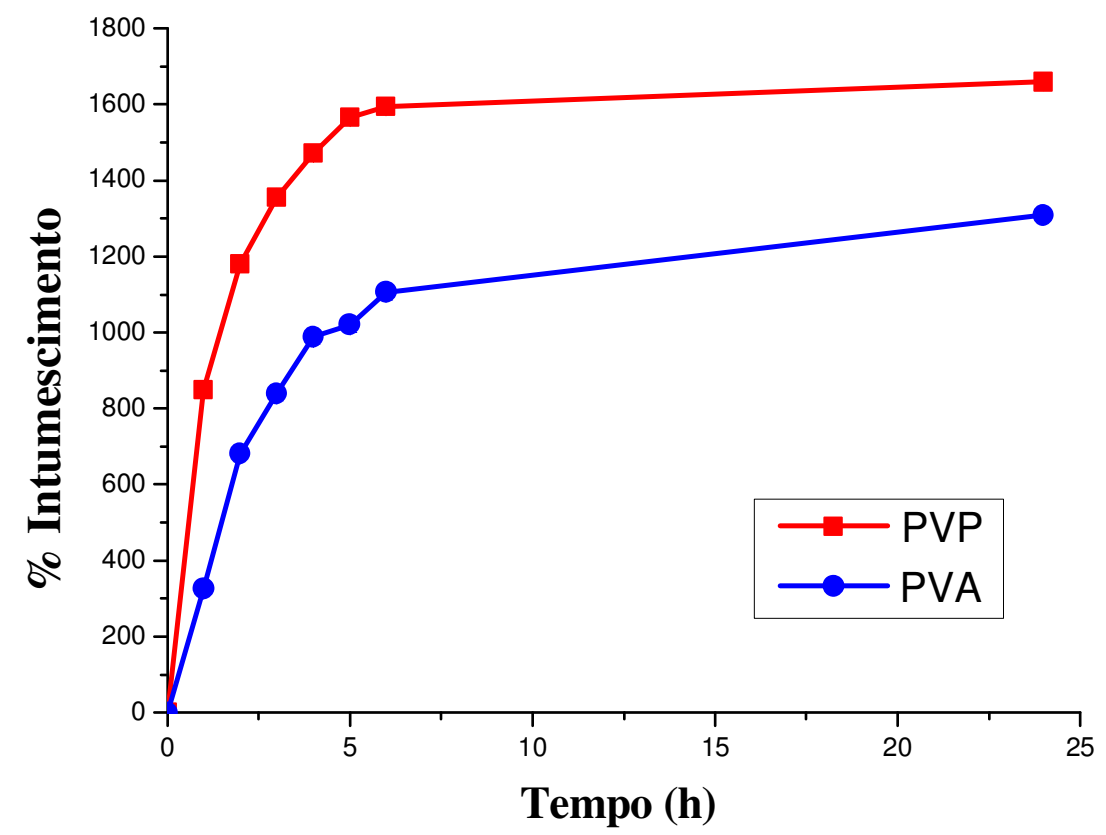

FIGURA 19. Perfil de intumescimento dos hidrogéis de PVP e PVA

\subsubsection{Citotoxicidade}

Para a avaliação da biocompatibilidade dos hidrogéis obtidos foi realizado o ensaio in vitro de citotoxicidade pelo método de incorporação do vermelho neutro. Este teste permite analisar a citotoxicidade ou reatividade biológica induzida pelo material testado em culturas celulares, tomando como parâmetro a viabilidade celular. Segundo Eisenbrand e colaboradores (2002), métodos que avaliam a citotoxicidade basal detectam a capacidade de um material em causar morte celular como conseqüência de danos na função básica da célula e apresentam boa correlação com a toxicidade aguda em animais e no homem.

Com os resultados de DO obtidos neste ensaio foi calculada a viabilidade celular em relação ao controle de células no ensaio, a qual foi considerada $100 \%$. Os resultados de viabilidade celular estão apresentados na TAB. 6. Projetando-se os valores de viabilidade celular em relação à concentração dos extratos foram obtidas as curvas de viabilidade celular, apresentadas na FIG. 20. $O$ índice de citotoxicidade $I_{50 \%}$ determina 
quantitativamente o potencial tóxico das amostras, indicando a concentração de extrato que provoca a morte de $50 \%$ da população celular. No ensaio, todas as amostras que apresentarem curvas de viabilidade celular acima da linha do $\mathrm{IC}_{50 \%}$ são consideradas não citotóxicas, como o controle negativo. As amostras que cortarem a linha do $\mathrm{IC}_{50 \%}$ pode-se obter o valor do índice de citotoxicidade na intersecção das linhas, e aquelas cujas curvas estiverem abaixo do $\mathrm{IC}_{50 \%}$ são consideradas citotóxicas.

TABELA 6. Resultados da viabilidade celular do ensaio de citotoxicidade in vitro dos hidrogéis de PVP e PVA.

\begin{tabular}{ccccc}
\hline CONCENTRAÇÃO & \multicolumn{4}{c}{ VIABILIDADE CELULAR (\%) } \\
& Controle & Controle & \\
DE EXTRATO (\%) & Positivo & Negativo & PVP & PVA \\
\hline 100 & $0 \pm 0$ & $99 \pm 15$ & $108 \pm 10$ & $83 \pm 8$ \\
50 & $22 \pm 21$ & $105 \pm 6$ & $85 \pm 4$ & $93 \pm 4$ \\
25 & $80 \pm 14$ & $100 \pm 7$ & $89 \pm 15$ & $97 \pm 9$ \\
12,5 & $97 \pm 12$ & $103 \pm 7$ & $78 \pm 7$ & $98 \pm 2$ \\
6,25 & $93 \pm 7$ & $104 \pm 5$ & $76 \pm 14$ & $82 \pm 5$ \\
\hline
\end{tabular}

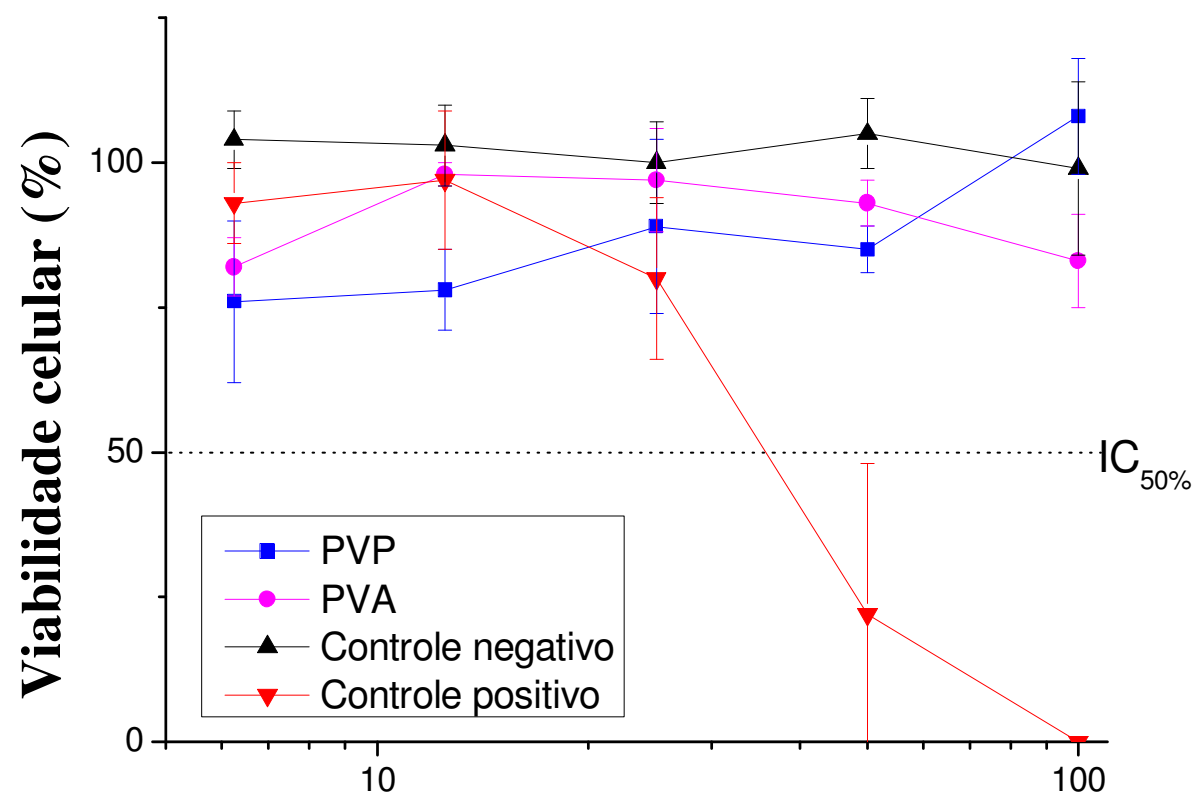

Concentração de extrato $(\%)$

FIGURA 20. Curvas de viabilidade celular dos hidrogéis de PVP e PVA no ensaio de citotoxicidade in vitro pelo método de incorporação do vermelho neutro. 
Conforme estudos anteriores encontrados na literatura, a biocompatibilidade dos hidrogéis de PVP (Higa, et.al., 1999) e PVA (Burczack et.al., 1996) foi comprovada. Assim como esperado, neste presente estudo, apenas o controle positivo apresentou toxicidade, com $I_{50 \%}$ igual a 37 , significando que o extrato do controle positivo na concentração de $37 \%$ provocou a morte da metade da população celular do ensaio. As amostras das membranas de hidrogel apresentaram comportamento semelhante ao controle negativo, mostrando as curvas de viabilidade celular acima da linha do $\mathrm{IC}_{50 \%}$, portanto tanto o hidrogel de PVP quanto o hidrogel de PVA não apresentaram efeito citotóxico. Isso significa que esses materiais são biologicamente seguros, cumprindo um dos requisitos de segurança exigidos para biomateiais.

\subsubsection{Propriedades Mecânicas}

As propriedades mecânicas estão associadas à habilidade do material resistir a forças mecânicas. O ensaio de resistência a tração avalia a tensão máxima requerida para deformação e, ou ruptura do material. O objetivo do ensaio é descrever o comportamento do material quando este é submetido a forças que tendem a puxá-lo separadamente (Nielsen, 1988).

Vários fatores estruturais podem influenciar o comportamento mecânico de materiais poliméricos, tais como: massa molecular, reticulações, ramificações, cristalinidade, morfologia cristalina, copolimerização, plastificação, entre outros (Macdermott, 1984).

Os principais parâmetros que quantificam a resistência mecânica dos polímeros nos ensaios de tração são: módulo elástico $(E)$, tensão na ruptura ( $\left.T_{\text {rup }}\right)$ e porcentagem de alongamento $(\varepsilon(\%))$.

Por meio dos ensaios de tração foram obtidas curvas de tensão $(\mathrm{N})$ versus deformação $(\mathrm{mm})$ como pode ser observado nas FiG. 21 e 22. Neste ensaio foram analisadas 8 amostras de cada tipo de hidrogel sendo que 3 delas foram selecionadas por apresentarem resultados reprodutíveis. 


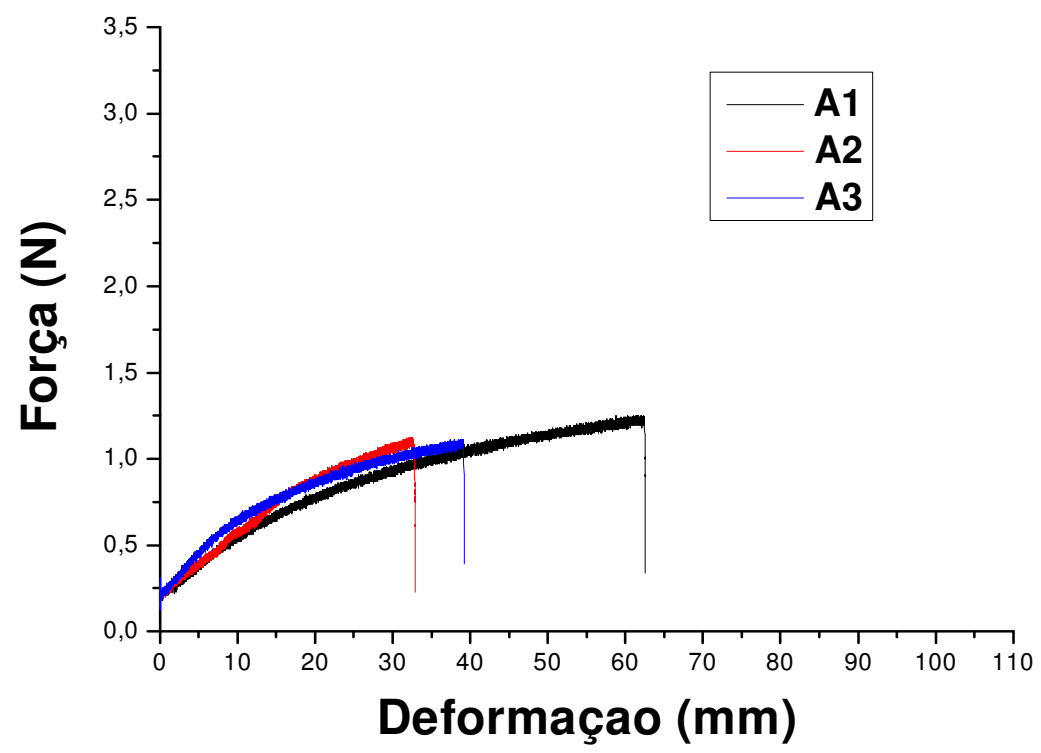

FIGURA 21. Performance da força de tração aplicada à membrana de PVP

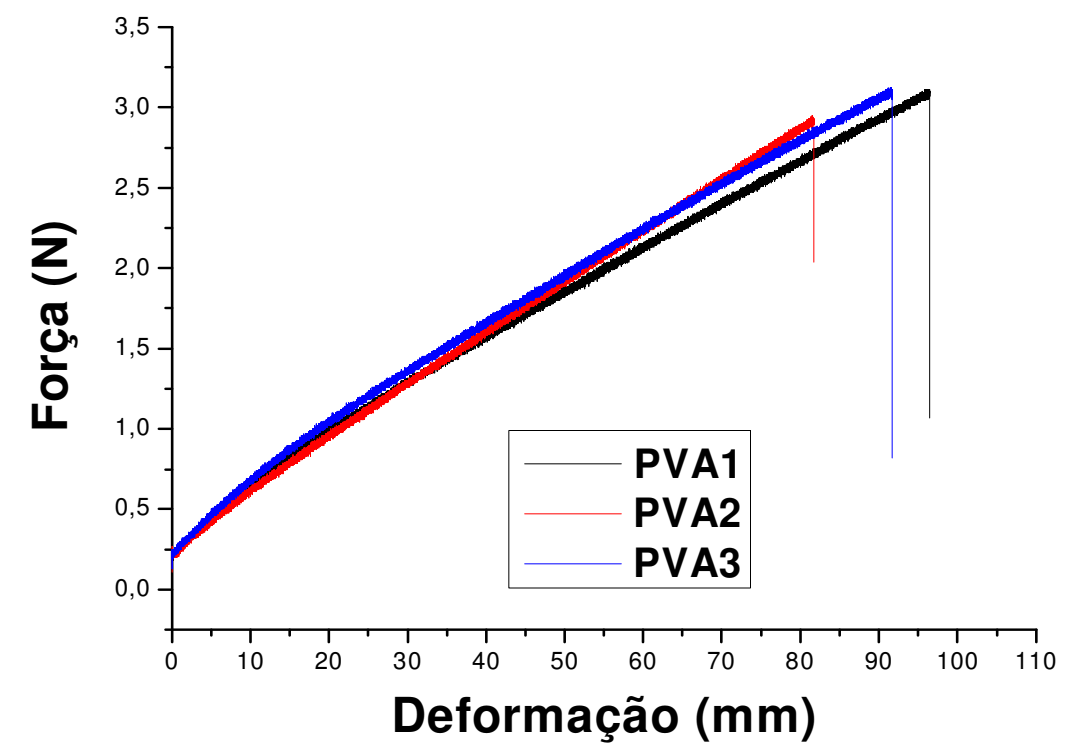

FIGURA 22. Performance da força de tração aplicada à membrana de PVA 
O Módulo de Elasticidade (E) foi calculado a partir da inclinação da linha de tensão na curva de deformação, uma vez que o coeficiente angular do trecho reto do diagrama Tensão(N) x Deformação $(\mathrm{mm})$ é sempre o mesmo.

A porcentagem de alongamento até a ruptura $(\varepsilon)$ foi calculada dividindo a elongação máxima pelo comprimento inicial $(60 \mathrm{~mm})$ e multiplicando por 100 .

Na TAB. 7 estão apresentados os resultados obtidos a partir da análise dos dados.

TABELA 7. Resultados de resistência máxima à tração, elongação e módulo elástico.

\begin{tabular}{cccc} 
AMOSTRAS & $\begin{array}{c}\text { Tensão na ruptura } \\
(\mathbf{T})\end{array}$ & $\begin{array}{c}\text { Alongamento } \\
(\boldsymbol{\varepsilon})\end{array}$ & $\begin{array}{c}\text { Módulo Elástico } \\
(\mathbf{E}) \\
\end{array}$ \\
$(\mathrm{N})$ & $(\%)$ & $(\mathrm{N})$ \\
\hline \hline PVA1 & 3,10 & 160,80 & 0,56 \\
PVA2 & 2,91 & 136,27 & 0,62 \\
PVA3 & 3,09 & 152,78 & 0,58 \\
\hline Média & 3,03 & 149,95 & 0,59 \\
\hline DP & 0,11 & 12,51 & 0,03 \\
\hline \hline PVP1 & 1,24 & 104,18 & 0,43 \\
PVP2 & 1,05 & 54,60 & 0,38 \\
PVP3 & 1,11 & 65,23 & 0,37 \\
\hline Média & 1,13 & 74,67 & 0,39 \\
\hline DP & 0,10 & 26,10 & 0,04 \\
\hline
\end{tabular}

Neste ensaio pode-se observar por meio do perfil da curva de Tensão(N) x Deformação $(\mathrm{mm})$ que a membrana de hidrogel de PVA possui uma maior resistência à tração e uma maior elongação em relação à de PVP. Segundo Hilmy e colaboradores (1993) a adição de ágar e PEG na composição de hidrogéis de PVP pode melhorar as propriedades mecânicas das membanas de PVP, mas, apesar do uso desses dois componentes na formulação deste hidrogel neste estudo, a membrana de hidrogel de PVA obteve uma maior resistência a tração, este comportamento pode ser atribuído ao maior número de ligações cruzadas, ou seja, uma maior densidade de reticulação. Em outro estudo encontrado na literatura, realizado por Yoshii e colaboradores (1995), foi verificado que a resistência a tração de membranas de hidrogel de PVA obtidas por reticulação química é inferior as obtidas por raios gama. Portanto, por meio 
desses estudos pode-se observar que os hidrogéis de PVA obtidos pela radiação ionizante apresentam melhores propriedades mecânicas.

\subsection{Citotoxicidade do Arct'Alg}

O ensaio de citotoxicidade do $\operatorname{Arct}^{\prime} \mathrm{Alg}^{\circledR}$ foi realizado para determinar a faixa de concentração a ser utilizada, deste princípio ativo, no ensaio de citoestimulação.

Este ensaio foi realizado conforme descrito no item 4.2.2.4 em materiais e métodos. Foi utilizado concentrações de 1, 2,5, 5 e 10\% do princípio ativo para a verificação de sua citotoxicidade e os resultados estão apresentados na TAB. 8.

TABELA 8. Resultados da viabilidade celular do ensaio de citotoxicidade do $\operatorname{Arct}^{\prime} \mathrm{Alg}^{\circledR}$.

\begin{tabular}{ccccc}
\hline \multicolumn{2}{c}{ CONCENTRAÇÃO (\%) } & \multicolumn{3}{c}{ VIABILIDADE CELULAR (\%) } \\
Controles & Arct'Alg $^{\circledR}$ & $\begin{array}{c}\text { Controle } \\
\text { Positivo }\end{array}$ & Controle Negativo & Arct'Alg $^{\circledR}$ \\
\hline 100 & -- & $0 \pm 0$ & $104 \pm 21$ & -- \\
50 & -- & $70 \pm 21$ & $103 \pm 14$ & -- \\
25 & -- & $87 \pm 10$ & $97 \pm 11$ & -- \\
12,5 & -- & $96 \pm 8$ & $99 \pm 15$ & -- \\
-- & 10 & -- & -- & $5 \pm 20$ \\
6,25 & -- & $110 \pm 18$ & $105 \pm 7$ & -- \\
-- & 5 & -- & -- & $25 \pm 21$ \\
-- & 2,5 & -- & -- & $75 \pm 17$ \\
-- & 1 & -- & -- & $76 \pm 14$ \\
\hline
\end{tabular}




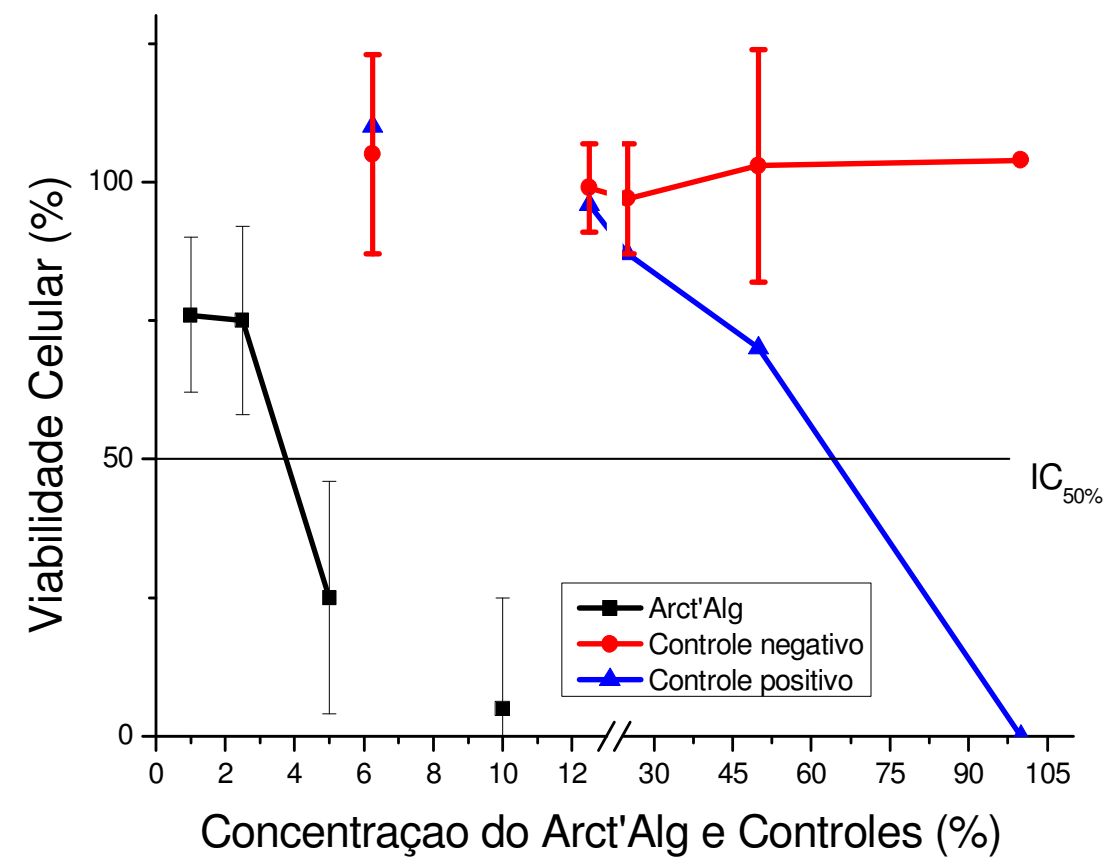

FIGURA 23. Curvas de viabilidade celular do $\operatorname{Arct}^{\prime} A l g{ }^{\circledR}$

As curvas de viabilidade celular do $\operatorname{Arct}^{\prime} \mathrm{Alg}^{\circledR}{ }^{\circledR}$ foram obtidas pela projeção dos dados de porcentagem de viabilidade celular em função da concentração do princípio ativo. Como pode ser observado na FIG. 23 as concentrações acima de $2,5 \%$ de $\operatorname{Arct'}^{\prime} \mathrm{Alg}^{\circledR}$ mostraram ser citotóxicas, cortando a linha do $\mathrm{IC}_{50 \%}$ na concentração de 3,8\%, indicando que nesta concentração de princípio ativo ocorreu a morte de metade da população celular do ensaio, portanto deverá ser utilizada uma concentração abaixo de 3,8\% no ensaio de citoestimulação. As curvas de viabilidade celular, nas concentrações de 2,5\% e $1 \%$ do Arct'Alg $^{\circledR}$, ficaram acima do $I_{50 \%}$, apresentando comportamento semelhante ao do controle negativo, ou seja, nestas concentrações o princípio ativo não apresentou efeito citotóxico nas células.

\subsection{Citoestimulação}

A característica citoestimulante do $\operatorname{Arct}^{\prime} \mathrm{Alg}^{\circledR}$ foi verificada pelo aumento do número de células fibroblásticas utilizando o método de incorporação do corante vermelho neutro. 
A propriedade de citoestimulação é de grande importância pelo fato dos fibroblastos serem células diretamente envolvidas no processo de reparação tecidual. Portanto, havendo o aumento do número de fibroblastos, ocorre conseqüentemente um aumento da produção de colágeno e elastina, favorecendo assim o processo de cicatrização (Junqueira \& Carneiro, 2008).

Os resultados obtidos neste ensaio mostraram que o princípio ativo utilizado possui uma atividade citoestimulante em algumas concentrações utilizadas, como pode ser observado na TAB. 9 e FIG.24.

TABELA 9. Resultados da viabilidade celular do ensaio de citoestimulação do $\operatorname{Arct'}^{\prime} \mathrm{Alg}^{\circledR}$.

\begin{tabular}{cc}
\hline CONCENTRAÇÃO DE & VIABILIDADE CELULAR (\%) \\
SFB (\%) em MEM + L-15 & \\
\hline 10 & $128 \pm 19$ \\
2 & $100 \pm 13$ \\
\hline \hline CONCENTRAÇÃO DE ARCT'ALG $^{\Theta}(\%)$ & $132 \pm 19$ \\
\hline 0,25 & $151 \pm 19$ \\
0,5 & $128 \pm 17$ \\
1 & $108 \pm 18$ \\
\hline
\end{tabular}

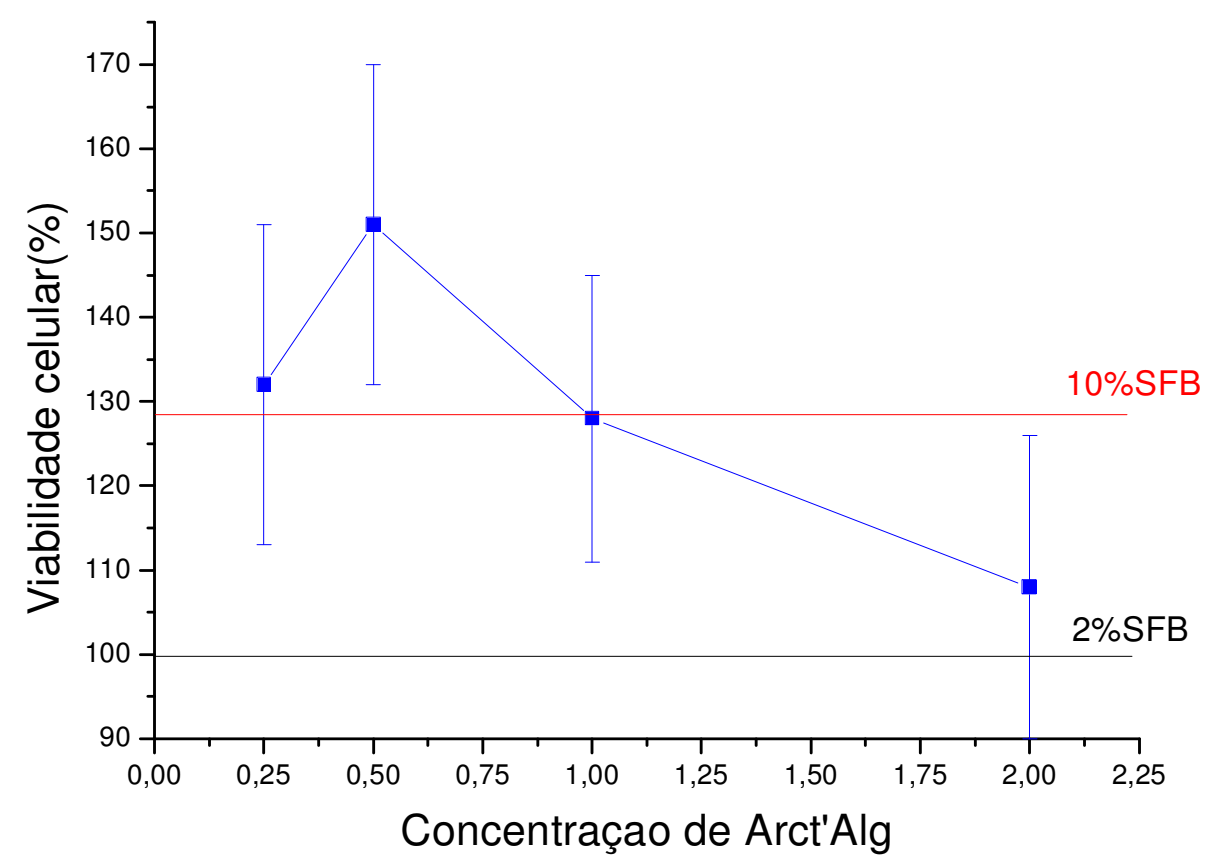

FIGURA 24. Viabilidade celular em função da concentração de $\operatorname{Arct}^{\prime} \mathrm{Alg}^{\circledR}$. 
$\mathrm{Na}$ concentração de $2 \%$ do $\operatorname{Arct}^{\prime} \mathrm{Alg}^{\circledR}$ não foi evidenciado um aumento significativo no número de células, obtendo um resultado bem próximo ao controle celular do ensaio. Nas concentrações de $0,25 \%$ e $1 \%$ obteve-se um aumento em cerca de $30 \%$, sendo este resultado semelhante ao obtido nas células que se encontravam em condição nutricional total (10\% SFB). O princípio ativo na concentração de $0,5 \%$ proporcionou um aumento de $50 \%$ no número de células do ensaio. Estes resultados demonstraram que as concentrações ideais do Arct'Alg $^{\circledR}$ para um aumento significativo no número de fibroblastos foram de 0,25 a $1 \%$, evidenciando a atividade citoestimulante do princípio ativo em estudo.

Em estudo realizado por Christophe (2006) sobre a atividade citoestimulante do dipeptídeo citrulil-arginina, principal constituinte do $\operatorname{Arct}^{\prime} \mathrm{Alg}^{\circledR}$, mostrou resultado semelhante ao deste estudo, sendo que em uma concentração de $0,05 \%$ do dipeptídeo, houve um aumento de aproximadamente $50 \%$ da população celular no ensaio.

\subsection{Estudo do comportamento do dipeptídeo citrulil-arginina irradiado}

Neste estudo foi utilizado o citrulil-arginina por ser o componente de maior interesse do Arct'Alg. O comportamento do dipeptídeo frente à radiação ionizante foi verificado para direcionar a escolha do método de incorporação do princípio ativo na membrana de hidrogel. A solução de citrulil-arginina foi irradiada na dose de 20 kGy devido esta ser a menor dose utilizada para obter as membranas de hidrogel.

Os resultados das análises obtidos no ensaio realizado em HPLC podem ser observados nas FIG. 25 e 26. No comprimento de onda de $200 \mathrm{~nm}$, o cromatograma do citrulil-arginina irradiado apresentou uma área de pico menor em relação ao do não irradiado e com presença de um outro pico que aparece no início da análise, sendo provavelmente produto de degradação do dipeptídeo pela ação da radiação. 


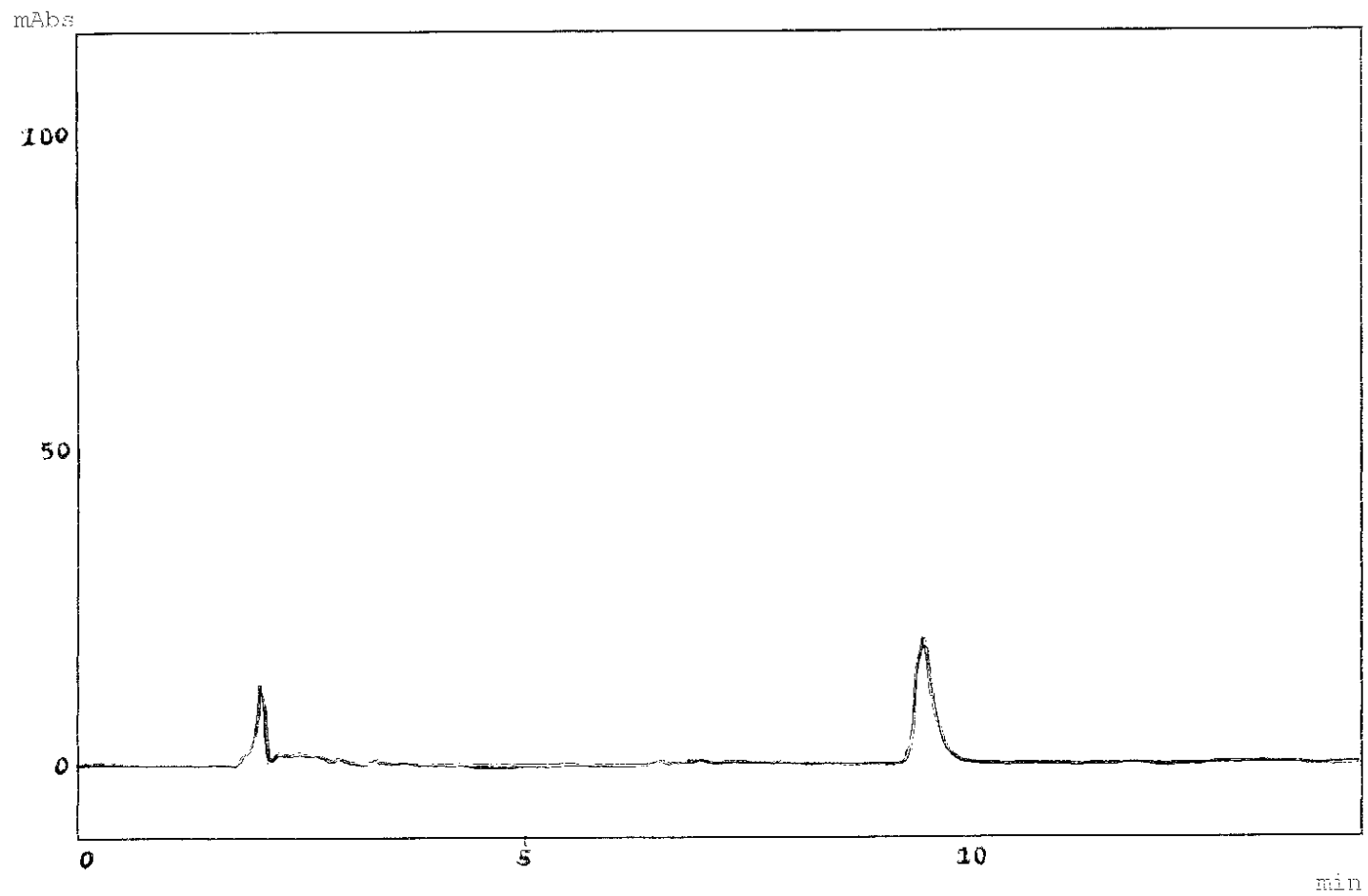

FIGURA 25. Cromatograma do citrulil-arginina irradiado

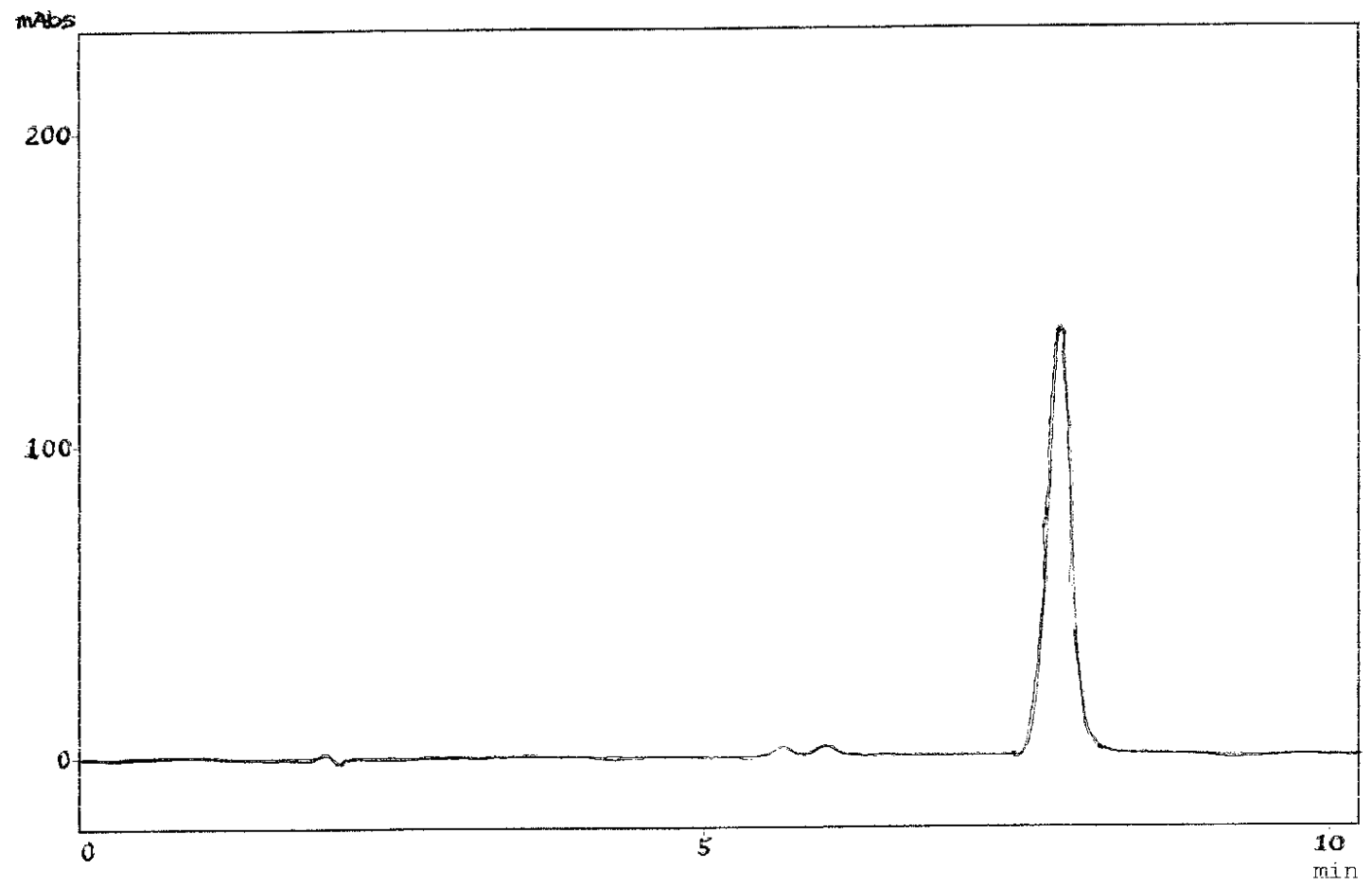

FIGURA 26. Cromatograma do citrulil-arginina não-irradiado 
$\mathrm{Na}$ TAB. 10 estão apresentados os resultados de tempo de retenção e área do pico. O dipeptídeo citrulil-arginina irradiado e não irradiado mostraram tempo de retenção semelhante, sendo ambos em cerca de $8 \mathrm{~min}$.

TABELA 10. Resultados do ensaio em HPLC: tempo de retenção e área do pico do dipeptídeo citrulil-arginina irradiado e não irradiado.

\begin{tabular}{ccc}
\hline citrulil-arginina & $\begin{array}{c}\text { tempo de retenção } \\
(\min )\end{array}$ & área do pico \\
\hline não-irradiado & 8.02 & 1834301 \\
Irradiado & 8.99 & 299607 \\
\hline
\end{tabular}

Em relação à área dos picos, pode-se observar que houve perda de massa do citrulil-arginina de cerca de $84 \%$ quando irradiado. Esta elevada perda de massa foi possivelmente pelo fato do dipeptídeo ter sido irradiado em solução aquosa, havendo assim reações das espécies produzidas pela radiólise da água.

\subsection{Obtenção do dispositivo de hidrogel}

Apesar do dipeptídeo citrulil-arginina apresentar perda de massa quando irradiado decidiu-se testar a incorporação direta do princípio ativo no hidrogel para verificar sua liberação. Esta tentativa baseia-se na hipótese de que o dipeptídeo seria protegido da ação da radiação pelos componentes da formulação, apesar da presença de água.

Os dispositivos de hidrogel de PVP e PVA contendo $3 \%$ de Arct'Alg $^{\circledR}$ foram obtidos conforme descritos no item 4.2.4.2 em materiais e métodos.

O critério para considerar os dispositivos adequados ou não para serem submetidos ao ensaio de liberação foi a formação de uma membrana homogênia, transparente, flexível, macia, com propriedades mecânicas adequadas para a manipulação. Os dispositivos de hidrogel de PVA e PVP foram avaliados visualmente e pelo tato, como podem ser observados nas FIG. 27 e 28 respectivamente. 


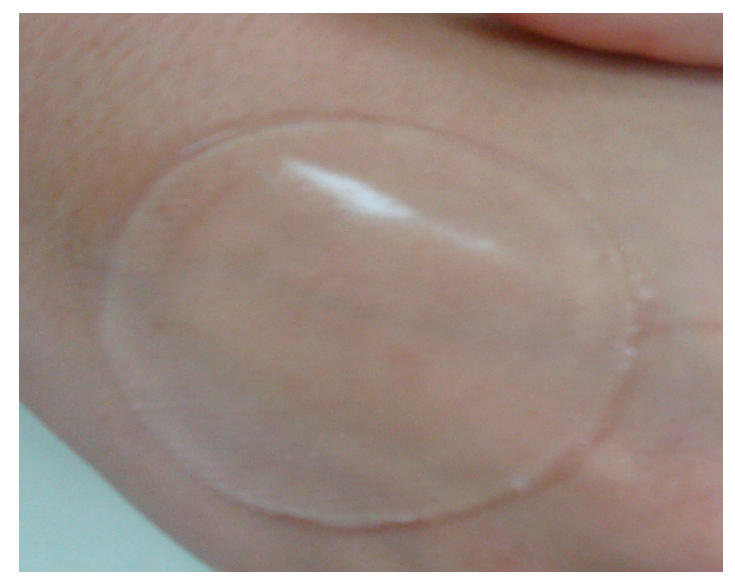

FIGURA 27. Dispositivo de hidrogel de PVA

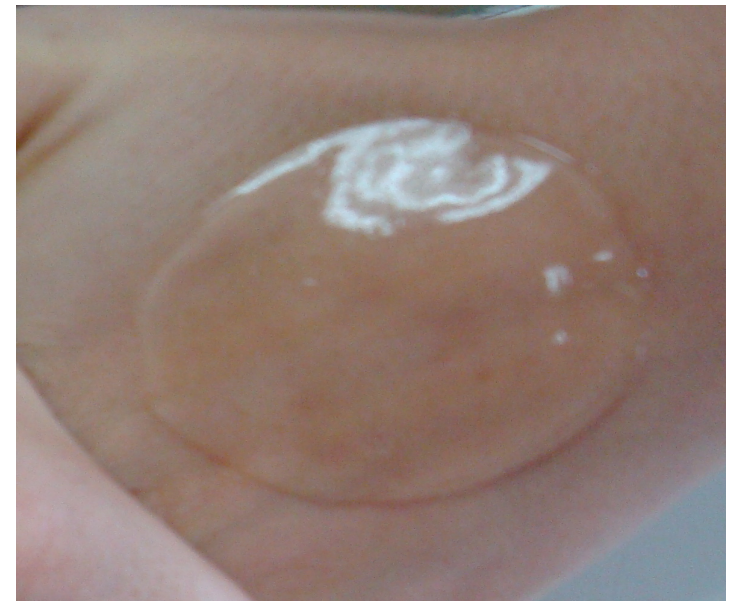

FIGURA 28. Dispositivo de hidrogel de PVP

\subsection{Cinética de liberação e doseamento do Arct'Alg ${ }^{\circledR}$}

O ensaio in vitro de liberação foi realizado para determinar o perfil de liberação do $\operatorname{Arct}^{\prime} \mathrm{Alg}^{\circledR}$ dos dispositivos de PVP e PVA obtidos. Para determinar a quantidade liberada de princípio ativo pelos dispositivos foram coletadas alíquotas em um determinado intervalo de tempo e quantificadas em HPLC conforme descrito no item 4.2.5 em materiais e métodos.

Para este ensaio foram utilizados dispositivos de PVP e PVA contendo $\operatorname{Arct}^{\prime} A{ }^{\circledR}{ }^{\circledR}$, dispositivos de PVP e PVA contendo citrulil-arginina e membranas das matrizes de PVP e PVA como controle do ensaio, sendo que as alíquotas coletadas do dispositivo contendo citrulil-arginina e das membranas controles 
foram utilizadas para uma análise comparativa dos cromatogramas dos mesmos com os do Arct'Alg ${ }^{\circledR}$ liberado.

Para verificar a liberação do $\operatorname{Arct}^{\prime} \mathrm{Alg}^{\circledR}{ }^{\circledR}$ (extrato composto por várias substâncias) foi utilizado como padrão o dipeptídeo citrulil-arginina, um de seus principais constituintes. A quantificação do citrulil-arginina contido no Arct'Alg $^{\circledR}$ liberado foi obtida pela comparação da área do pico de uma solução padrão de $0,2 \mathrm{mg} / \mathrm{mL}$ do citrulil-arginina com a área do pico da citrulil-arginina liberado do dispositivo contendo o Arct'Alg $^{\circledR}$.

A área do pico do citrulil-arginina foi obtida pela injeção de $5 \mu \mathrm{L}$ da solução padrão em uma coluna de fase reversa C18 conforme descrito no item 4.2.3.2. Na FIG. 29 apresenta-se o cromatograma do padrão em que se observa 0 pico no tempo de retenção de aproximadamente 8 min.

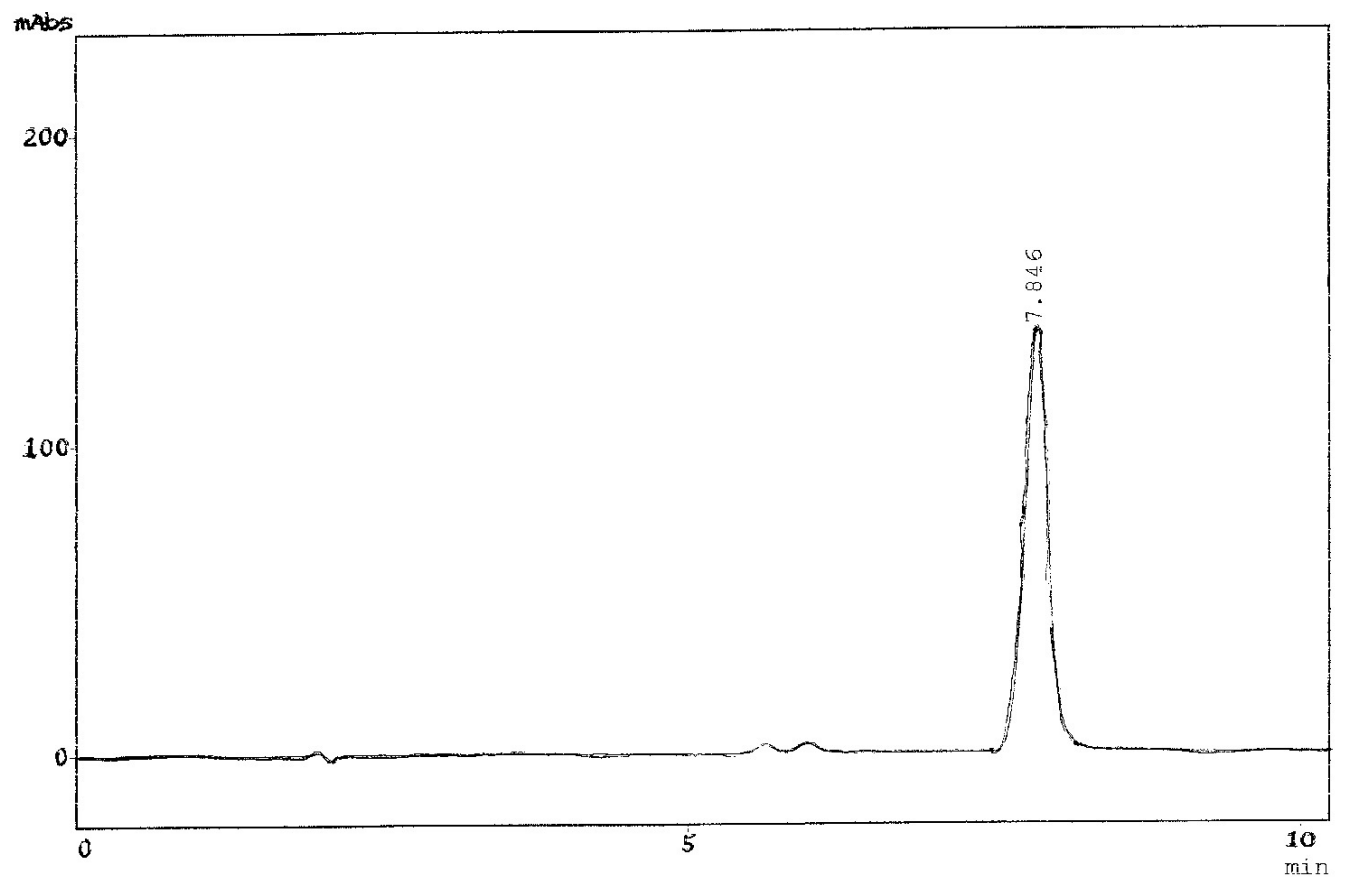

FIGURA 29. Cromatograma da solução padrão de citrulil-arginina

Na quantificação do $\operatorname{Arct'}^{\prime} \mathrm{Alg}^{\circledR}$ liberado dos dispositivos de PVP e PVA foi considerado o pico do dipeptídeo citrulil-arginina. Os cromatogramas obtidos após $1 \mathrm{~h}$ de liberação do dispositivo de PVP com $\operatorname{Arct'}^{\prime} \mathrm{Alg}^{\circledR}$ e da matriz controle de PVP podem ser observados nas FIG. 30 e 31 respectivamente. 


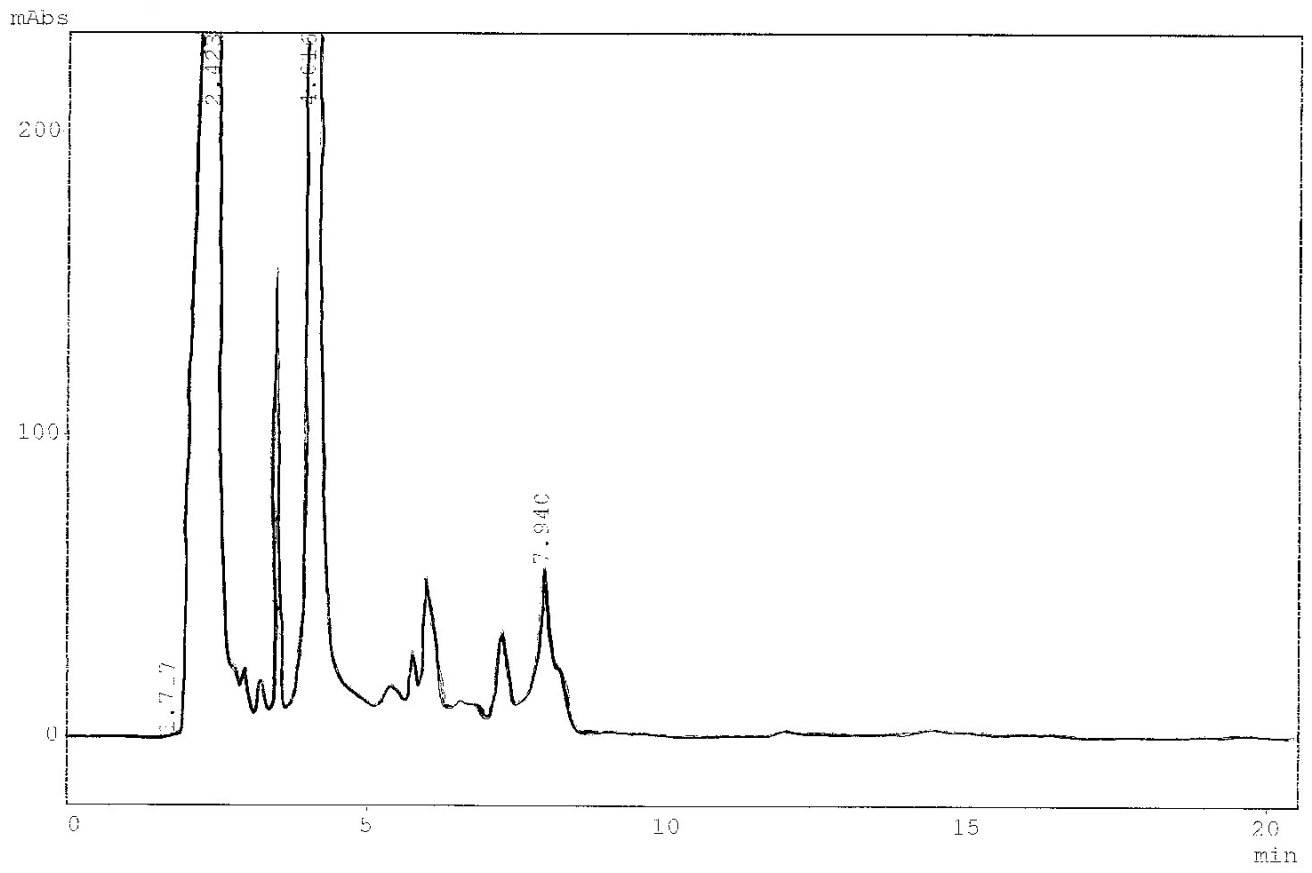

FIGURA 30. Cromatograma de cinética de liberação do dispositivo de PVP contendo $\operatorname{Arct'Alg}^{\circledR}$ após 1h de liberação.

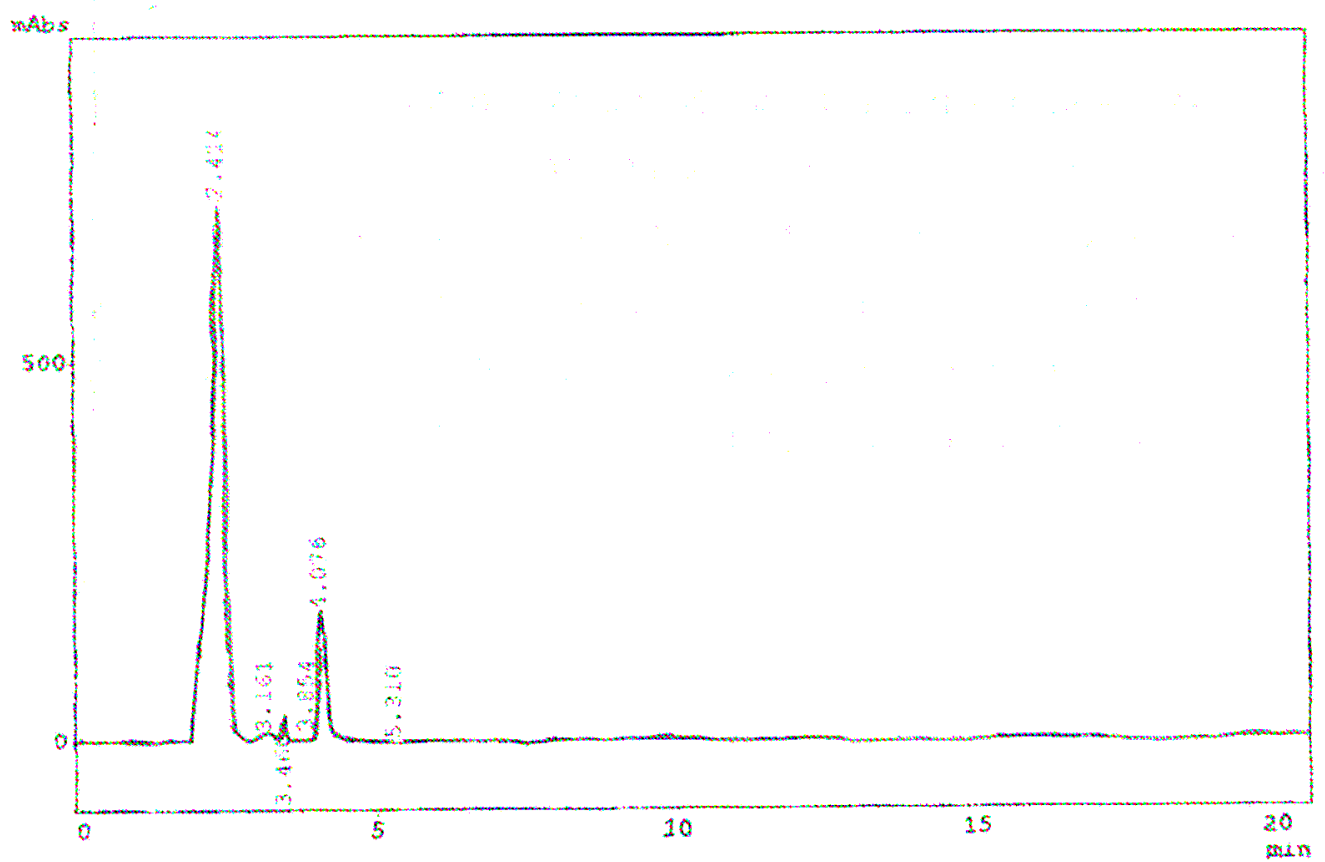

FIGURA 31. Cromatograma do extrato da membrana controle de PVP 
As FIG. 32 e 33 apresentam os cromatogramas obtidos após $1 \mathrm{~h}$ de liberação do dispositivo de PVA contendo $\operatorname{Arct}^{\prime} \mathrm{Alg}^{\circledR}$ e da matriz controle de PVA respectivamente.

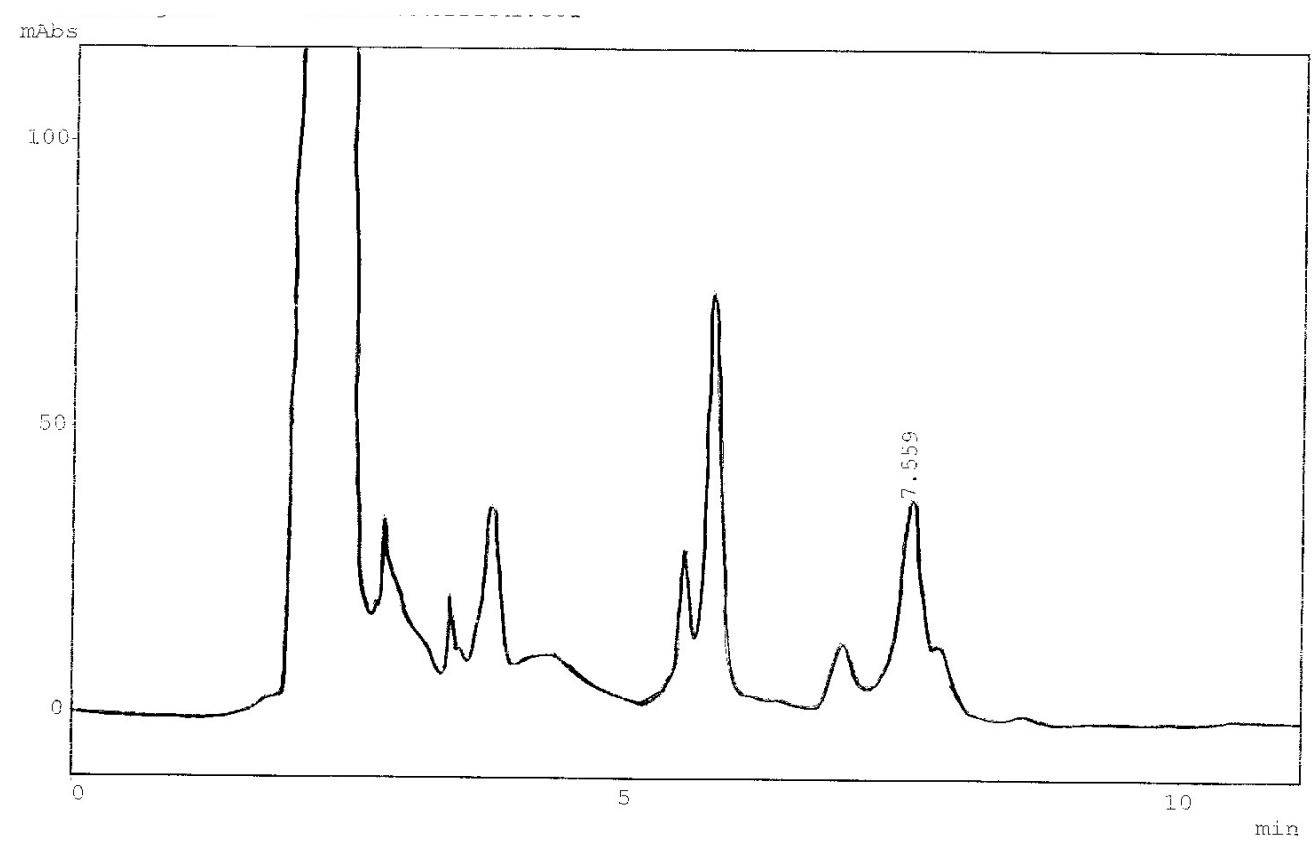

FIGURA 32. Cromatograma de cinética de liberação do dispositivo de PVA contendo Arct'Alg ${ }^{\circledR}$ após $1 \mathrm{~h}$ de liberação.

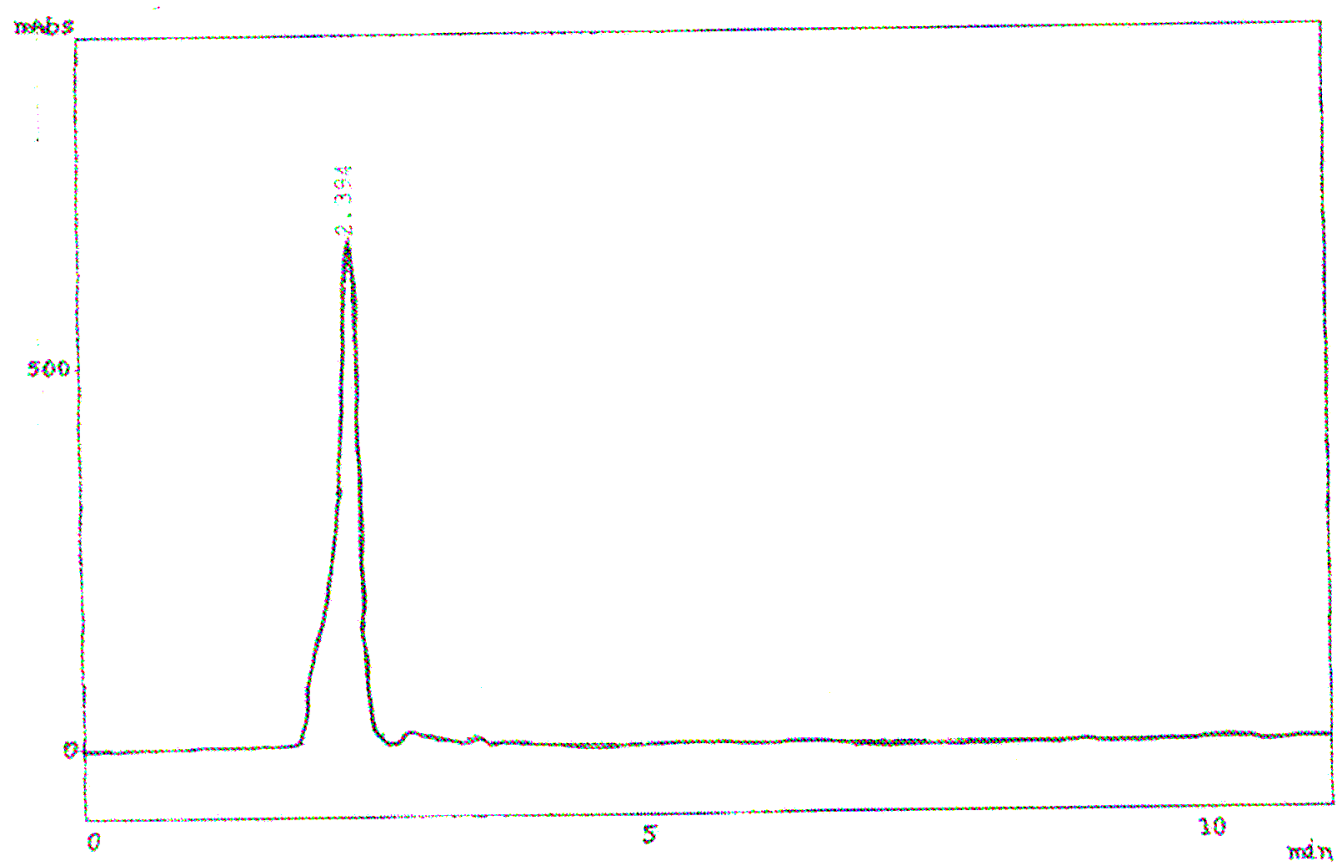

FIGURA 33. Cromatograma do extrato da membrana controle de PVA 
Nos cromatogramas das alíquotas de cinética de liberação apresentados nas FIG. 30 e 32 encontra-se o pico do dipeptídeo citrulil-arginina com tempo de retenção de cerca de $8 \mathrm{~min}$, muito próximo do tempo de retenção do padrão.

Nos cromatogramas das FIG. 31 e 33, correspondente às membranas controle de PVP e PVA, não se observa o pico no tempo de retenção do padrão. Observa-se somente picos no início do cromatograma e estes podem ser observados nos cromatogramas dos dispositivos correspondentes.

Para comprovar que o pico obtido em torno de 8 min das amostras de $\operatorname{Arct'Alg}^{\circledR}$ liberado é o dipeptídeo citrulil-arginina, foi incorporado este dipeptídeo em membranas de PVA. Na análise de liberação em HPLC, o cromatograma obtido apresentou tempo de retenção semelhante aos picos obtidos nos cromatogramas dos dispositivos com Arct'Alg $^{\circledR}$. Na FIG. 34 apresenta-se 0 cromatograma do dispositivo de PVA com citrulil-arginina.

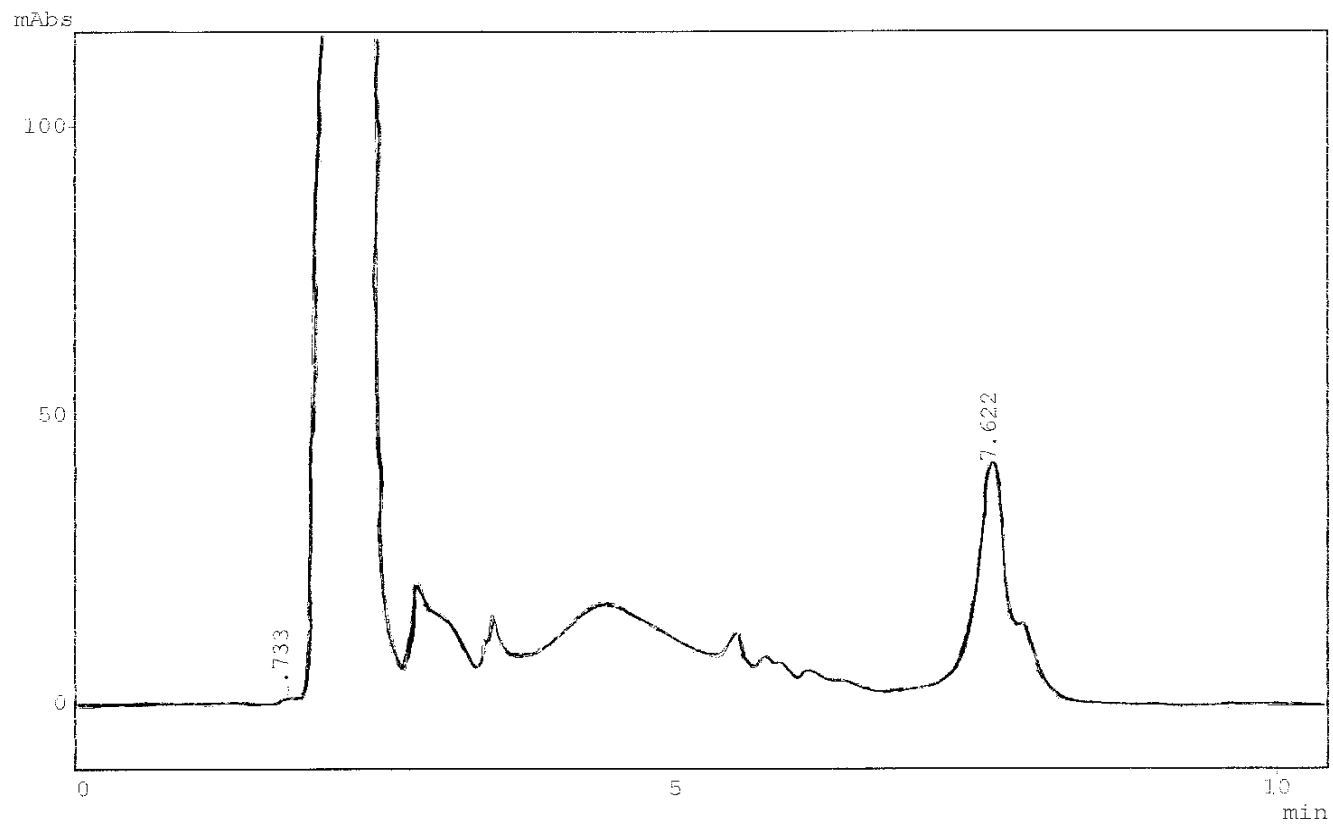

FIGURA 34. Cromatograma da análise em HPLC do dispositivo de PVA contendo citrulil-arginina

A concentração de citrulil-arginina liberada dos dispositivos preparados com Arct'Alg $^{\circledR}$ foi calculada pela comparação das áreas dos picos correspondentes à área do pico da solução padrão. A quantidade de citrulil- 
arginina padrão no volume injetado corresponde a $1 \mu \mathrm{g}$ de citrulil-arginina que forneceu uma área de pico de 1834301. Assim, com esta área do pico obtida, foi possível calcular a concentração de citrulil-arginina nas alíquotas da cinética de liberação do $\operatorname{Arct'Alg}^{\circledR}$, cujos resultados estão apresentados na TAB. 11.

TABELA 11. Resultados do ensaio da cinética de liberação do citrulil-arginina dos dispositivos de PVP e PVA analisado em HPLC

\begin{tabular}{ccccc} 
DISPOSITIVO & $\begin{array}{c}\text { TEMPO DE } \\
\text { LIBERAÇÃO } \\
(\mathrm{h})\end{array}$ & $\begin{array}{c}\text { TEMPO DE } \\
\text { RETENÇÃO } \\
(\mathrm{min})\end{array}$ & $\begin{array}{c}\text { ÁREA DO } \\
\text { PICO }\end{array}$ & $\begin{array}{c}\text { CITRULIL-ARGININA } \\
(\mu \mathrm{g} / \mathrm{mL})\end{array}$ \\
\hline \multirow{4}{*}{ PVP } & 1 & 7,94 & 1102231 & 6,009 \\
& 2 & 7,48 & 938004 & 5,114 \\
& 3 & 8,02 & 916417 & 4,996 \\
& 4 & 7,59 & 824082 & 4,493 \\
& 5 & 7,96 & 839009 & 4,574 \\
& 6 & 7,56 & 828229 & 4,515 \\
& 7 & 7,51 & 818832 & 4,464 \\
PVA & 7,6 & 842494 & 4,593 \\
& 1 & 7,55 & 667615 & 3,639 \\
& 2 & 7,66 & 653028 & 3,56 \\
& 3 & 7,59 & 626414 & 3,415 \\
& 4 & 7,64 & 621342 & 3,387 \\
& 5 & 7,59 & 616679 & 3,362 \\
& 6 & 7,61 & 503148 & 2,743 \\
& 7 & 7,61 & 509028 & 2,775 \\
& 24 & 7,59 & 493516 & 2,69 \\
\hline
\end{tabular}

Para obter a concentração liberada real dos dispositivos foram realizados alguns cálculos partindo das concentrações do citrulil-arginina encontradas em $100 \mu \mathrm{L}$. Primeiramente a concentração do dipeptídeo em $\mu \mathrm{g} / \mathrm{mL}$ obtida no ensaio em HPLC foi multiplicada por $35 \mathrm{~mL}$ para se ter a concentração total liberada. Após este cálculo foi feito uma correção das concentrações, pois a cinética de liberação foi realizada com reposição da solução tampão a cada retirada de alíquota. Para fazer esta correção foi somada a concentração total liberada do citrulil-arginina com a concentração obtida em $100 \mu \mathrm{L}$ da coleta anterior.

O perfil de liberação do citrulil-arginina contido no $\operatorname{Arct}^{\prime} A^{\circledR}{ }^{\circledR}$ dos dispositivos de PVP e PVA estão apresentados nas FIG. 35 e 36. 


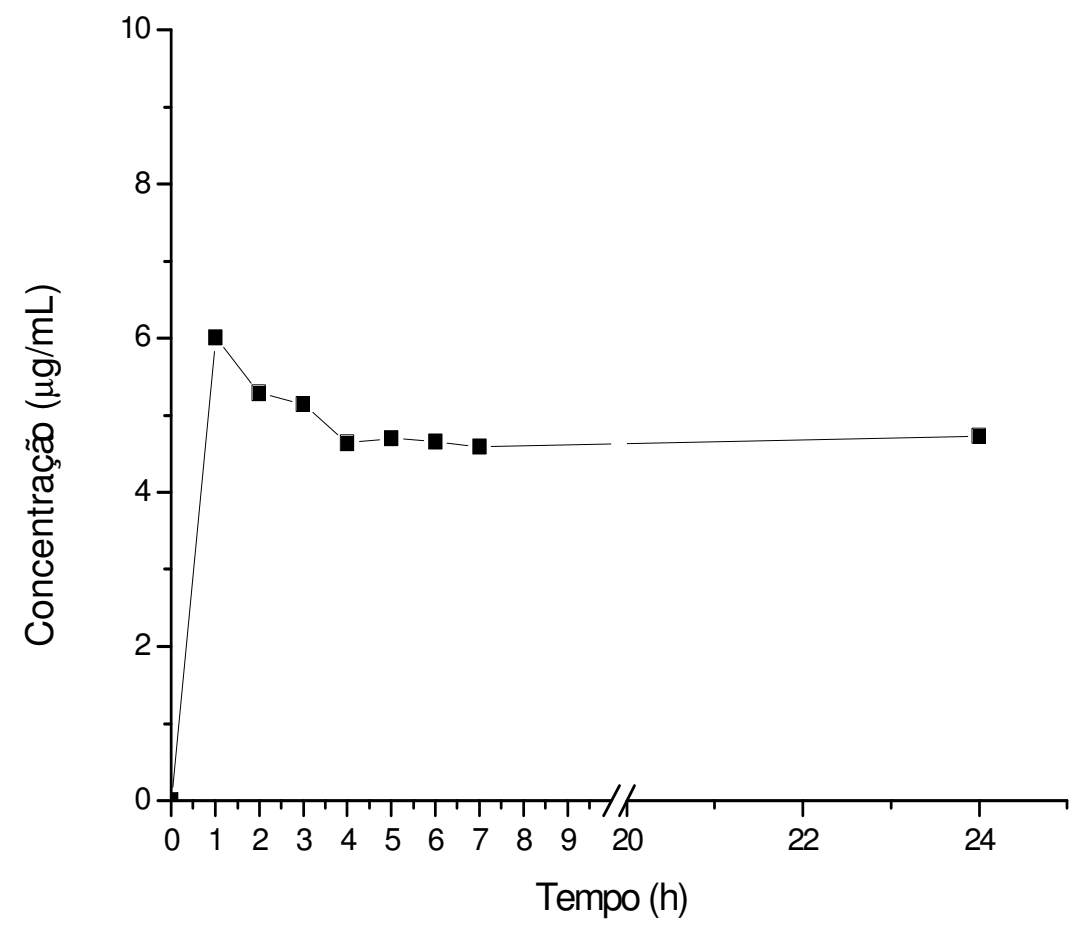

FIGURA 35. Perfil de liberação do citrulil-arginina contido no $\operatorname{Arct'Alg}^{\circledR}$ do dispositivo de PVP

Analisando os resultados da TAB. 11 e o perfil de liberação do dispositivo de PVP verifica-se que houve a liberação total do $\operatorname{Arct'Alg}^{\circledR}$ na primeira hora do ensaio, pois em até 24h não houve aumento no nível de liberação.

No caso do dispositivo de PVA o comportamento foi similar, como observado na TAB. 11 e FIG. 36. 


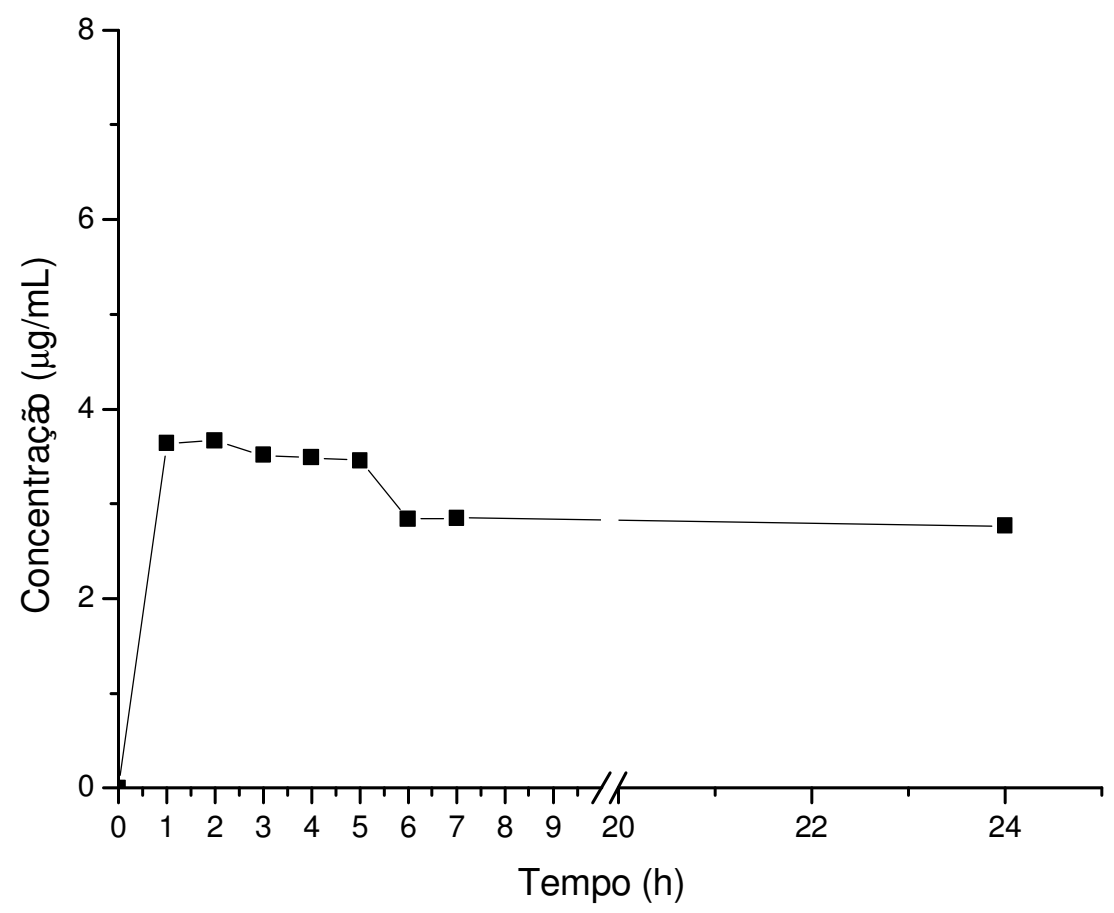

FIGURA 36. Perfil de liberação do citrulil-arginina contido no $\operatorname{Arct}^{\prime} A l g{ }^{\circledR}$ do dispositivo de PVA

Segundo Burczack e colaboradores (1994) a área disponível para a difusão do soluto é o espaço livre que existe entre as cadeias macromoleculares de hidrogéis. Quando os espaços entre as cadeias forem preenchidos por água ou fluidos biológicos, alcançando equilíbrio de intumescimento, essas cadeias se alongarão e o princípio ativo se difundirá para fora da matriz de hidrogel. Este comentário pode explicar a liberação total do Arct' Alg da matriz de hidrogel de PVA e de PVP na primeira hora de ensaio, pois provavelmente o espaço entre as cadeias dos hidrogéis é maior que a massa molar do princípio ativo, facilitando assim a sua difusão.

Outro estudo encontrado na literatura que poderia explicar a liberação total de Arct'Alg $^{\circledR}$ do dispositivo de PVP na primeira hora do ensaio é o estudo realizado por Sen e colaboradores (2007), que mostram que a utilização de PEGs hidrossolúveis de baixo peso molecular na preparação de hidrogéis por radiação 
gama, não se reticula e consequentemente aumenta o tamanho dos poros no hidrogel formado havendo assim uma maior facilidade na difusão do princípio ativo.

Comparando a porcentagem de $\operatorname{Arct}^{\prime} \mathrm{Alg}^{\circledR}$ liberado entre os dispositivos, o de PVP liberou cerca de $50 \%$ e o de PVA em torno de $30 \%$ em relação a quantidade de Arct'Alg ${ }^{\circledR}$ incorporado conforme apresentado na TAB. 12. Deve-se ressaltar que o dipeptídio citrulil-arginina, quando submetido à radiação, apresentou $80 \%$ de perda de massa, portanto sugere-se que os componentes da formulação dos hidrogéis protegeram o princípio ativo e provavelmente esta porcentagem liberada é a quantidade total que se encontrava no dispositivo. No entanto, não se pode eliminar a possibilidade do ativo estar retido na rede polimérica, tendo em vista a afinidade química. Para elucidar exatamente o mecanismo em pauta, ensaios de extração ou microscopia eletrônica são de grande ajuda, porém fugiam ao previsto em nossa proposta.

TABELA 12. Porcentagem de liberação de $\operatorname{Arct'Alg}^{\circledR}$ a partir dos dispositivos de hidrogéis

\begin{tabular}{cccc}
\hline DISPOSITIVO & $\begin{array}{c}\text { TEMPO DE LIBERAÇÃO } \\
(\mathrm{h})\end{array}$ & $\begin{array}{c}\text { CITRULIL-ARGININA } \\
(\mathrm{mg})\end{array}$ & $\begin{array}{c}\text { LIBERAÇÂO DE ARCT'ALG }^{\circledR} \\
(\%)\end{array}$ \\
\hline & 1 & 0,421 & 53,3 \\
& 2 & 0,370 & 46,8 \\
PVP & 3 & 0,359 & 45,6 \\
& 4 & 0,324 & 41,1 \\
& 5 & 0,329 & 41,6 \\
& 6 & 0,325 & 41,1 \\
& 7 & 0,321 & 40,7 \\
PVA & 24 & 0,330 & 41,6 \\
\hline & 1 & 0,255 & 32,2 \\
& 2 & 0,256 & 32,4 \\
& 3 & 0,246 & 31,2 \\
& 4 & 0,244 & 30,9 \\
& 5 & 0,242 & 30,6 \\
& 6 & 0,198 & 25,2 \\
& 7 & 0,199 & 25,3 \\
& 24 & 0,194 & 24,5 \\
\hline
\end{tabular}




\subsection{Atividade citoestimulante do Arct'Alg $^{\circledR}$ liberado}

O Arct'Alg ${ }^{\circledR}$ liberado in vitro em meio fisiológico (MEM e L-15 (v/v) com $2 \%$ SFB) foi avaliado quanto a sua atividade citoestimulante pelo método da incorporação do vermelho neutro.

O Arct'Alg $^{\circledR}$ liberado do dispositivo de PVP apresentou um aumento significativo do crescimento celular em relação ao controle de células no ensaio, em cerca de $80 \%$, sendo que as células que se encontravam em condição nutricional total (MEM e L-15 com 10\% SFB) apresentou crescimento de cerca de $22 \%$, como mostra a FIG. 37.

Em relação ao dispositivo de PVA, no ensaio de citoestimulação, não mostrou aumento significativo do número de células, sendo o resultado bem próximo ao controle celular no ensaio.

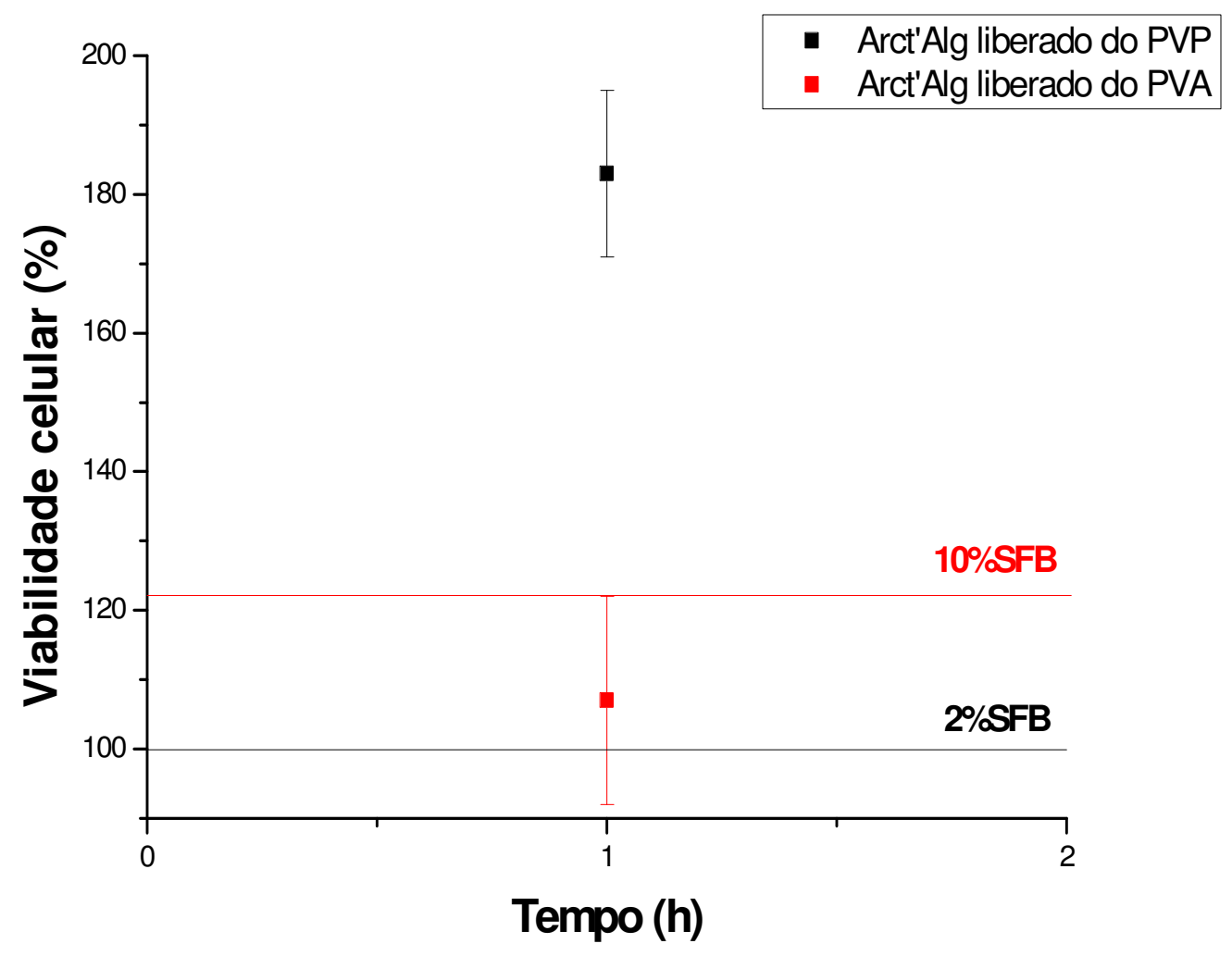

FIGURA 37. Viabilidade celular do $\operatorname{Arct}^{\prime} A{ }^{\circledR}{ }^{\circledR}$ liberado na primeira hora dos dispositivos de hidrogéis de PVP e PVA 
Estes resultados demonstraram que nas condições do ensaio in vitro o dispositivo de PVP liberou uma quantidade adequada de $\operatorname{Arct}^{\prime} \mathrm{Alg}^{\circledR}$ para promover a estimulação do crescimento de células fibroblásticas e que o princípio ativo mesmo após irradiação em 25 kGy ainda mantinha sua propriedade de citoestimulação. 


\section{CONCLUSÃO}

De acordo com os resultados obtidos nos ensaios de caracterização da matriz polimérica pode-se concluir que os hidrogéis de PVP e PVA apresentaram características adequadas para serem utilizados como dispositivos de liberação de princípios ativos. Ambas as matrizes não apresentaram efeito tóxico no ensaio de citotoxicidade e obtiveram um grau de reiculação e intumescimento elevado. Apesar da membrana de PVA ser mais resistente que a de PVP, não foi descartada a possibilidade de seu uso, pois a mesma apresentou uma resistência adequada ao manuseio durante o ensaio.

O estudo da cinética de liberação do $\operatorname{Arct'Alg}^{\circledR}$ mostrou que a incorporação deste princípio ativo nos hidrogéis, antes de serem irradiados, é possível, pois tanto no dispositivo de PVP quanto no de PVA houve liberação, sendo em cerca de $50 \%$ e $30 \%$ respectivamente. Apesar de ocorrer a liberação do princípio ativo a partir do dispositivo de PVA, este não foi suficiente para promover a citoestimulação das células fibrobláticas. Esta propriedade foi observada somente na amostra do Arct'Alg $^{\circledR}$ liberado a partir do dispositivo de PVP, em que houve um aumento em cerca de $80 \%$ da população celular em relação ao controle do ensaio.

Portanto, por meio dos resultados analisados, pode-se concluir que o dispositivo de PVP liberou uma concentração adequada de $\operatorname{Arct}^{\prime} A g^{\circledR}{ }^{\circledR}$ para promover a citoestimulação, sendo nestas condições, o mais adequado para ser utilizado em processos de reparação cutânea. 


\section{APÊNDICE}

\section{APÊNDICE A - Ensaio de citoestimulação com 200.000 céls $/ \mathrm{mL}$}

TABELA 13. Resultados da viabilidade celular do ensaio de citoestimulação do Arct'Alg $^{\circledR}$ em microplaca contendo 200.000 céls $/ \mathrm{mL}$.

\begin{tabular}{cc}
\hline CONCENTRAÇÃO DE & VIABILIDADE CELULAR (\%) \\
SFB (\%) em MEM + L-15 & \\
\hline 10 & $85 \pm 15$ \\
5 & $100 \pm 16$ \\
\hline \hline CONCENTRAÇÃO DE ARCT'ALG $^{\circledast}$ & \\
$(\%)$ & $92 \pm 15$ \\
0,25 & $85 \pm 19$ \\
0,5 & $87 \pm 19$ \\
1 & $91 \pm 12$ \\
2 &
\end{tabular}

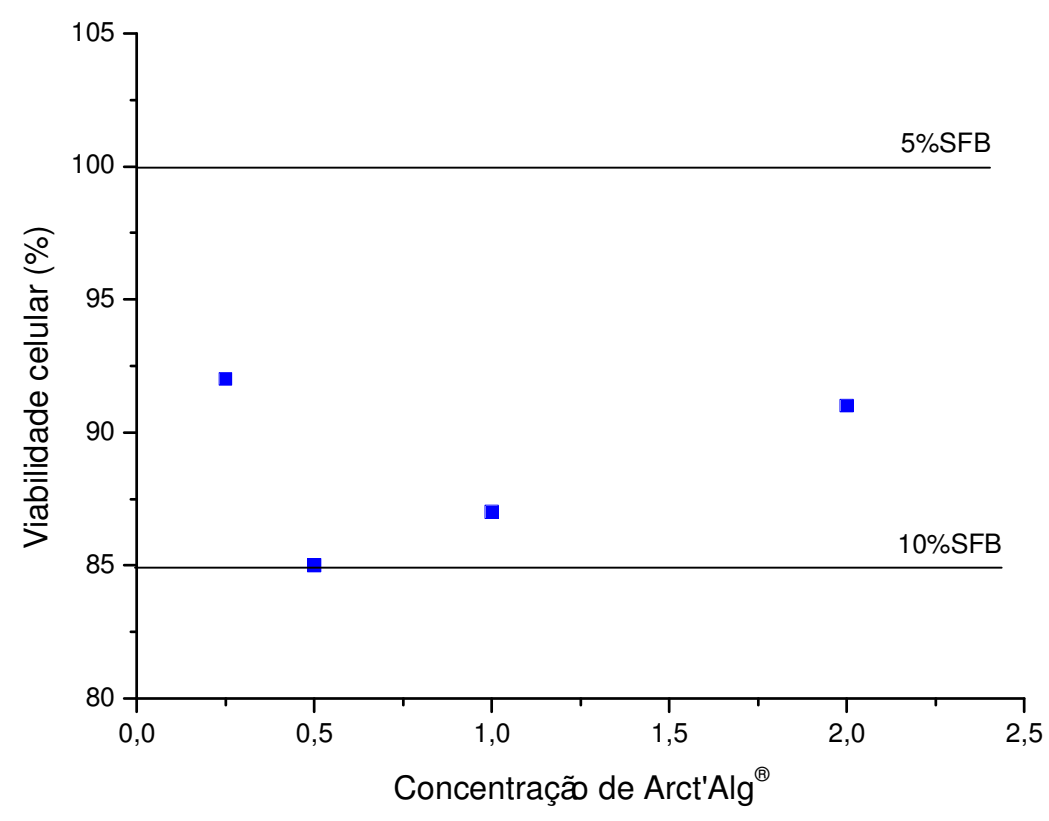

FIGURA 38. Viabilidade celular em função da concentração de $\operatorname{Arct}^{\prime} \mathrm{Alg}^{\circledR} \mathrm{em}$ microplaca contendo 200.000 céls $/ \mathrm{mL}$. 


\section{APÊNDICE B - Ensaio de citoestimulação para a padronização do número de células $/ \mathrm{mL}$}

TABELA 14. Resultados da viabilidade celular do ensaio de citoestimulação do Arct'Alg ${ }^{\circledR}$ em microplaca contendo 180.000 céls $/ \mathrm{mL}$.

\begin{tabular}{cc}
\hline CONCENTRAÇÃO DE & VIABILIDADE CELULAR (\%) \\
SFB (\%) em MEM + L-15 & \\
\hline 10 & $98 \pm 15$ \\
5 & $100 \pm 15$ \\
\hline \hline CONCENTRAÇÃO DE ARCT'ALG ${ }^{\Theta}$ & \\
\hline$\%)$ & $106 \pm 13$ \\
0,25 & $111 \pm 12$ \\
1 & $105 \pm 15$ \\
2 & $104 \pm 14$ \\
\hline
\end{tabular}

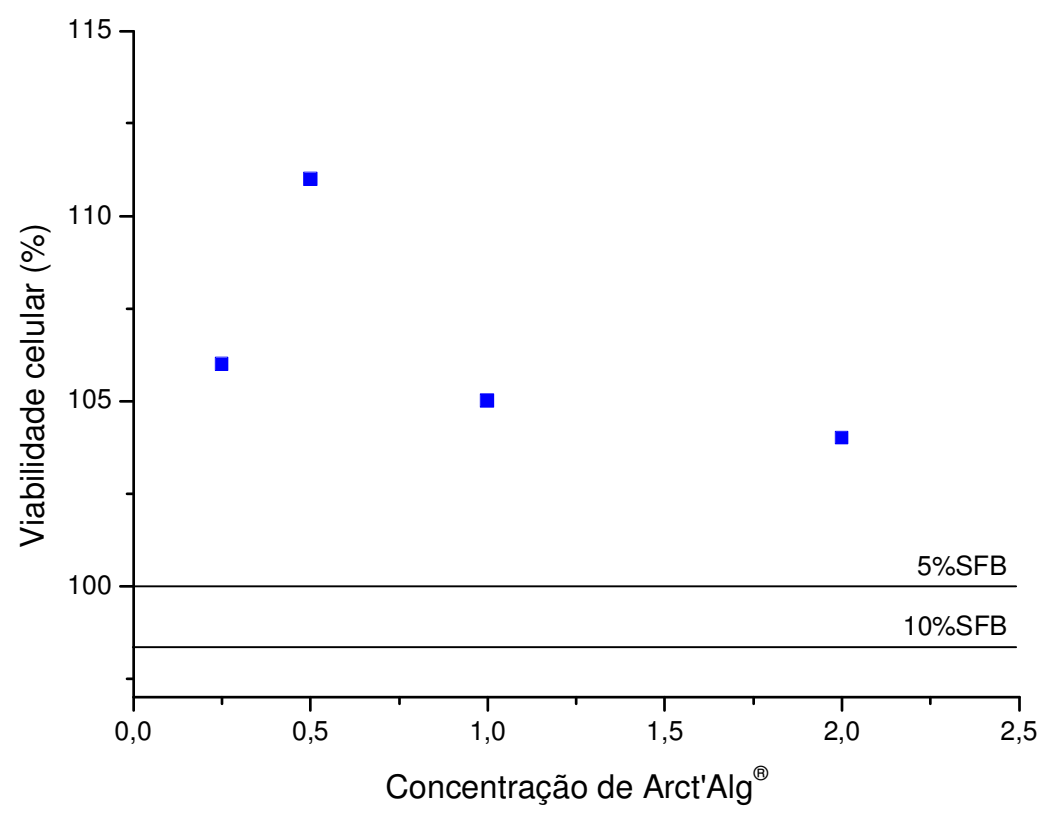

FIGURA 39. Viabilidade celular em função da concentração de $\operatorname{Arct}^{\prime} \mathrm{Alg}^{\circledR} \mathrm{em}$ microplaca contendo 180.000 céls $/ \mathrm{mL}$. 
TABELA 15. Resultados da viabilidade celular do ensaio de citoestimulação do Arct'Alg ${ }^{\circledR}$ em microplaca contendo 150.000 céls $/ \mathrm{mL}$.

\begin{tabular}{cc}
\hline CONCENTRAÇÃO DE & VIABILIDADE CELULAR (\%) \\
SFB (\%) em MEM + L-15 & \\
\hline 10 & $72 \pm 19$ \\
5 & $100 \pm 18$ \\
\hline \hline CONCENTRAÇẪO DE ARCT'ALG $^{\Theta}$ & \\
\hline \%) & $102 \pm 18$ \\
0,25 & $109 \pm 18$ \\
1 & $112 \pm 14$ \\
2 & $96 \pm 15$ \\
\hline
\end{tabular}

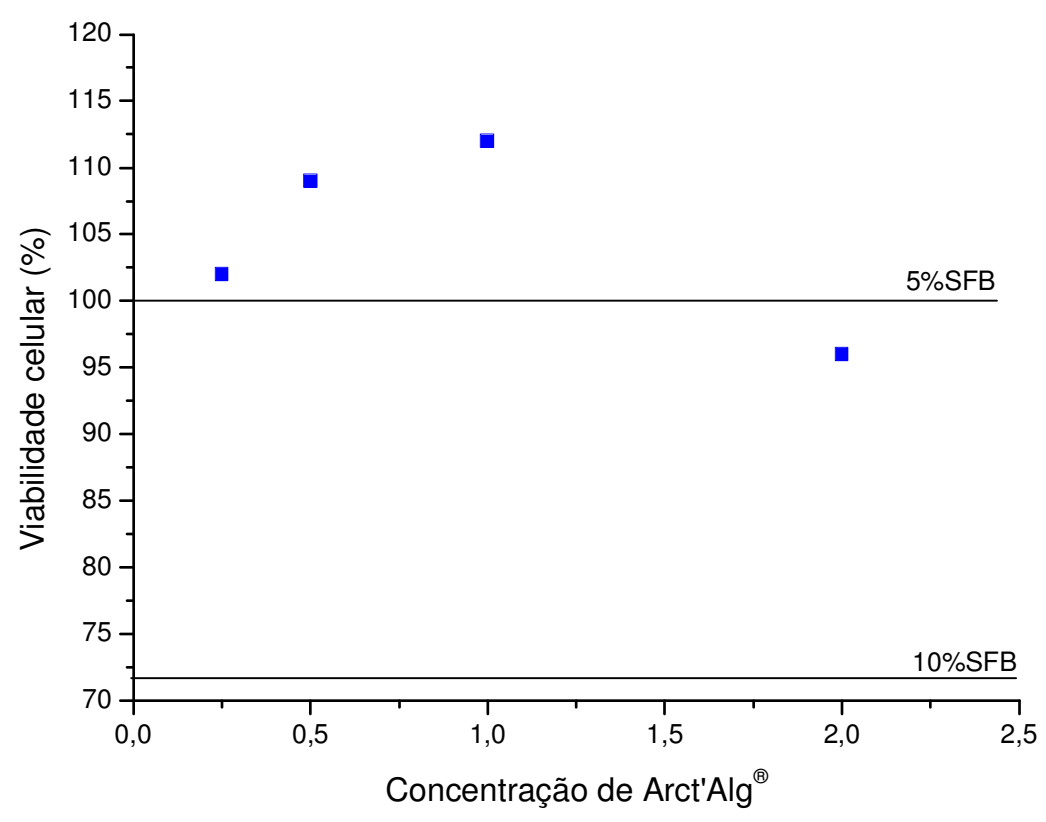

FIGURA 40. Viabilidade celular em função da concentração de $\operatorname{Arct'}^{\prime} \mathrm{Alg}^{\circledR} \mathrm{em}$ microplaca contendo 150.000 céls $/ \mathrm{mL}$. 
TABELA 16. Resultados da viabilidade celular do ensaio de citoestimulação do Arct'Alg $^{\circledR}$ em microplaca contendo 100.000 céls $/ \mathrm{mL}$.

\begin{tabular}{cc}
\hline CONCENTRAÇÃO DE & VIABILIDADE CELULAR (\%) \\
SFB (\%) em MEM + L-15 & \\
\hline 10 & $97 \pm 13$ \\
5 & $100 \pm 16$ \\
\hline \hline CONCENTRAÇAिO DE ARCT'ALG $^{\Theta}$ & \\
\hline$\%)$ & $120 \pm 15$ \\
0,25 & $125 \pm 11$ \\
0,5 & $122 \pm 18$ \\
1 & $118 \pm 16$ \\
\hline
\end{tabular}

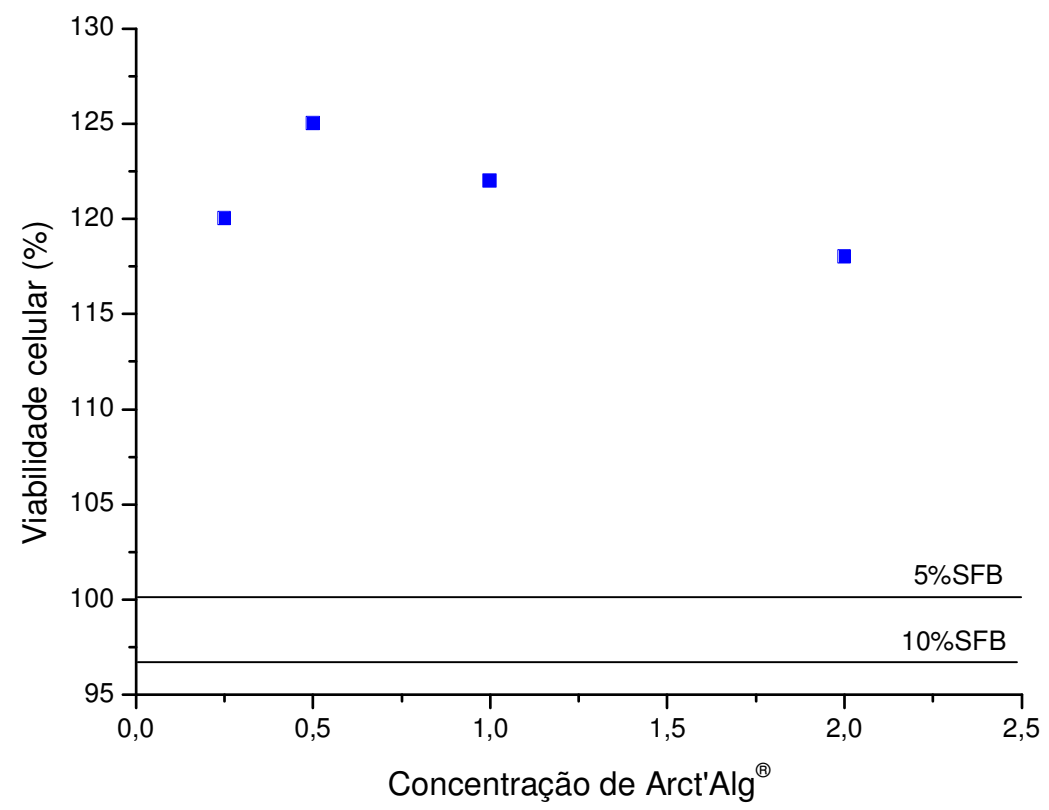

FIGURA 41. Viabilidade celular em função da concentração de $\operatorname{Arct'}^{\prime} \mathrm{Alg}^{\circledR} \mathrm{em}$ microplaca contendo 100.000 céls $/ \mathrm{mL}$. 


\section{APÊNDICE C - Ensaio de citoestimulação para padronização de SFB}

TABELA 17. Resultados da viabilidade celular em função do uso de MEM com diferentes concentrações de SFB.

\begin{tabular}{cc}
\hline CONCENTRAÇÃO DE SFB (\%) & VIABILIDADE CELULAR (\%) \\
\hline 15 & $117 \pm 17$ \\
10 & $124 \pm 18$ \\
5 & $108 \pm 12$ \\
2 & $100 \pm 17$ \\
\hline
\end{tabular}

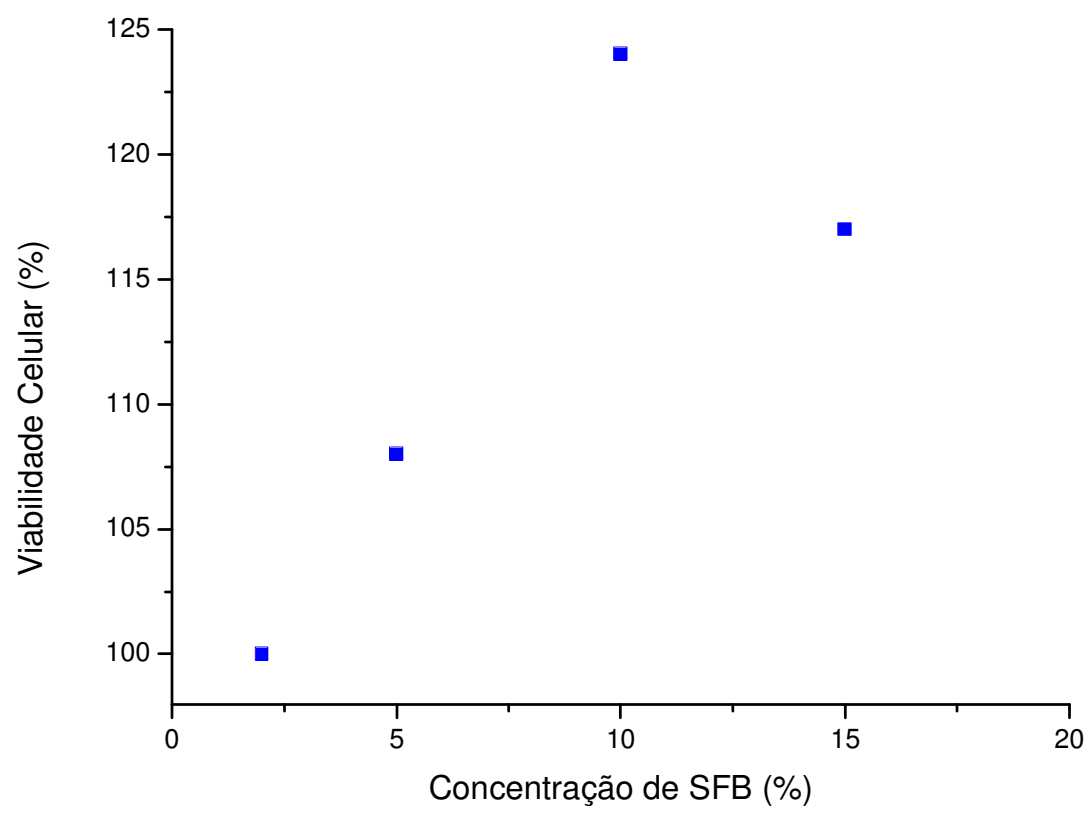

FIGURA 42. Viabilidade celular em função do uso de MEM com diferentes concentrações de SFB. 
APÊNDICE D - Ensaio de citoestimulação para a padronização de SFB no MEM + L-15

TABELA 17. Resultados da viabilidade celular em função da concentração de SFB no MEM + L-15.

\begin{tabular}{cc}
\hline CONCENTRAÇÃO DE & VIABILIDADE CELULAR (\%) \\
SFB (\%) em MEM + L-15 & $121 \pm 18$ \\
\hline 15 & $127 \pm 14$ \\
10 & $103 \pm 18$ \\
5 & $100 \pm 11$ \\
\hline
\end{tabular}

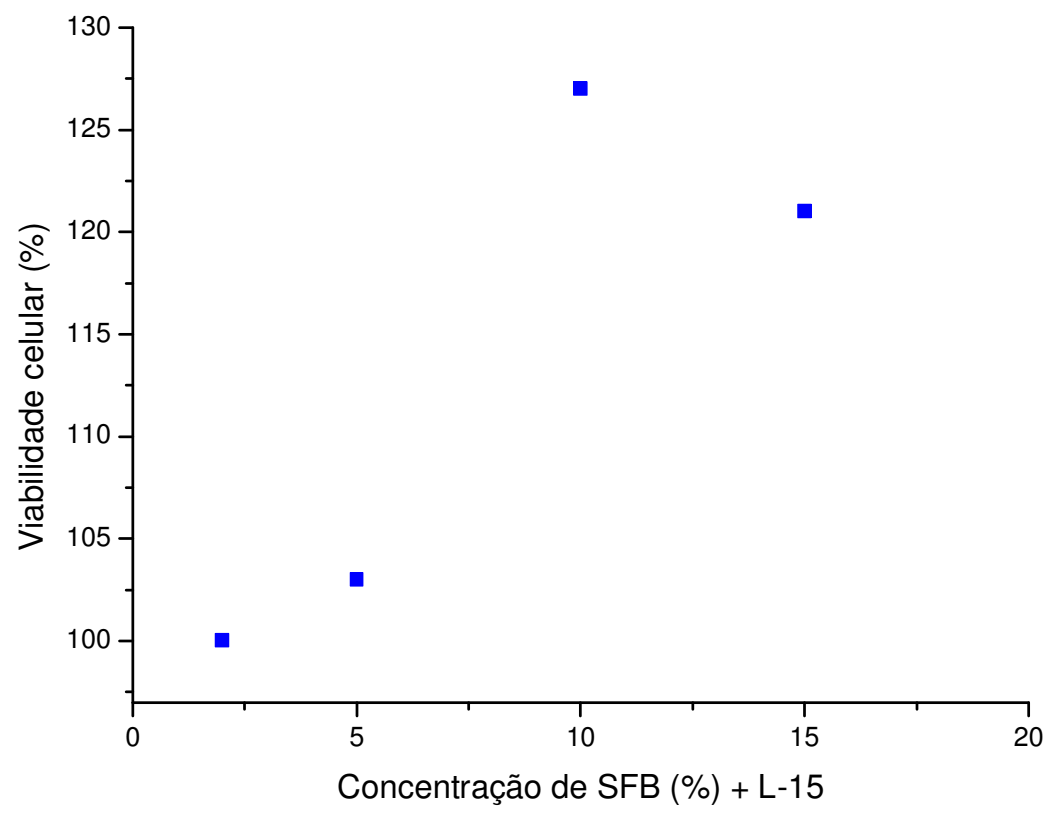

FIGURA 43. Viabilidade celular em função da concentração de SFB no MEM + L-15. 


\section{APÊNDICE E - Ensaio de citoestimulação com incubação da microplaca por 24 horas}

TABELA 18. Resultados da viabilidade celular em função da concentração de Arct’Alg $^{\circledR}$ com incubação da microplaca por 24 horas.

\begin{tabular}{cc}
\hline CONCENTRAÇÃO DE & VIABILIDADE CELULAR (\%) \\
SFB (\%) em MEM + L-15 & \\
\hline 10 & $102 \pm 17$ \\
2 & $100 \pm 18$ \\
\hline \hline CONCENTRAÇÃO DE ARCT'ALG \\
$(\%)$ & \\
\hline 0,25 & $102 \pm 17$ \\
0,5 & $109 \pm 19$ \\
1 & $107 \pm 17$ \\
2 & $103 \pm 19$ \\
\hline
\end{tabular}

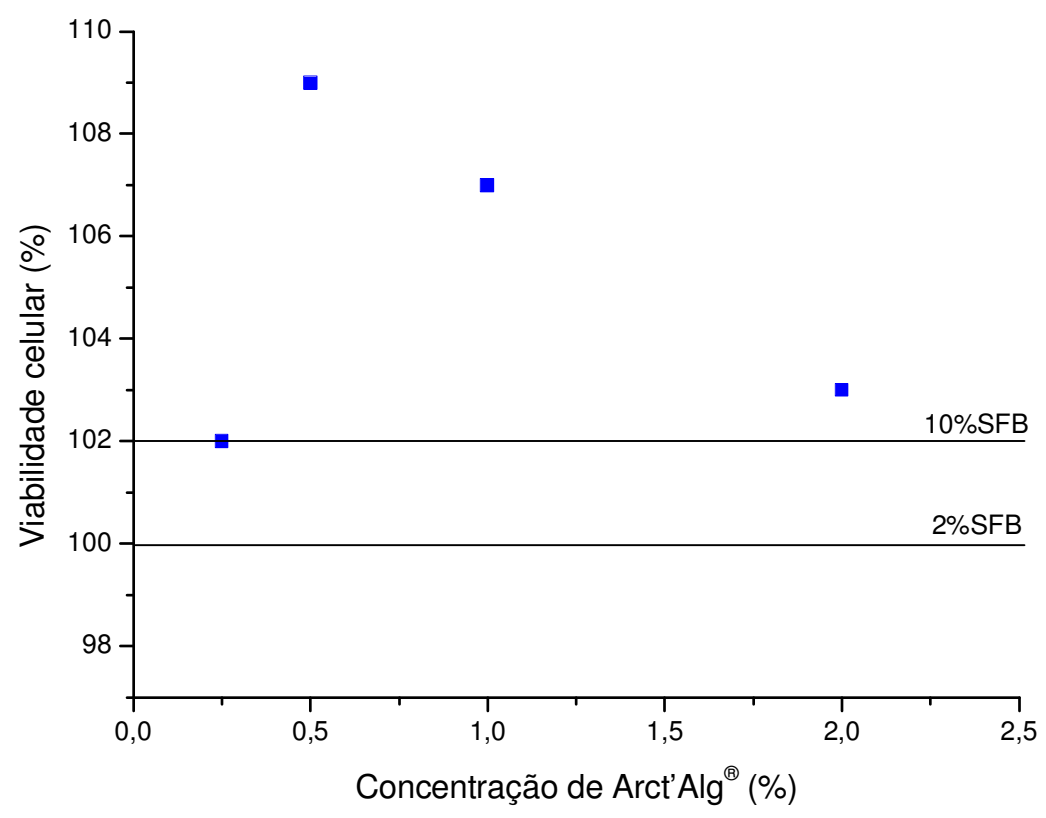

FIGURA 44. Viabilidade celular em função da concentração de $\operatorname{Arct'Alg}^{\circledR}$ com incubação da microplaca por 24 horas 


\section{APÊNDICE F - Ensaio de citoestimulação com incubação da microplaca por 48 horas}

TABELA 19. Resultado da viabilidade celular em função da concentração de $\operatorname{Arct'Alg}^{\circledR}$ com incubação da microplaca por 48 horas - ensaio 1.

\begin{tabular}{cc}
\hline CONCENTRAÇÃO DE & VIABILIDADE CELULAR (\%) \\
SFB (\%) em MEM + L-15 & \\
\hline 10 & $122 \pm 17$ \\
2 & $100 \pm 18$ \\
\hline \hline CONCENTRAÇAO DE ARCT'ALG & \\
$(\%)$ & $127 \pm 12$ \\
0,25 & $147 \pm 13$ \\
0,5 & $122 \pm 19$ \\
1 & $109 \pm 16$ \\
2 & \\
\hline
\end{tabular}

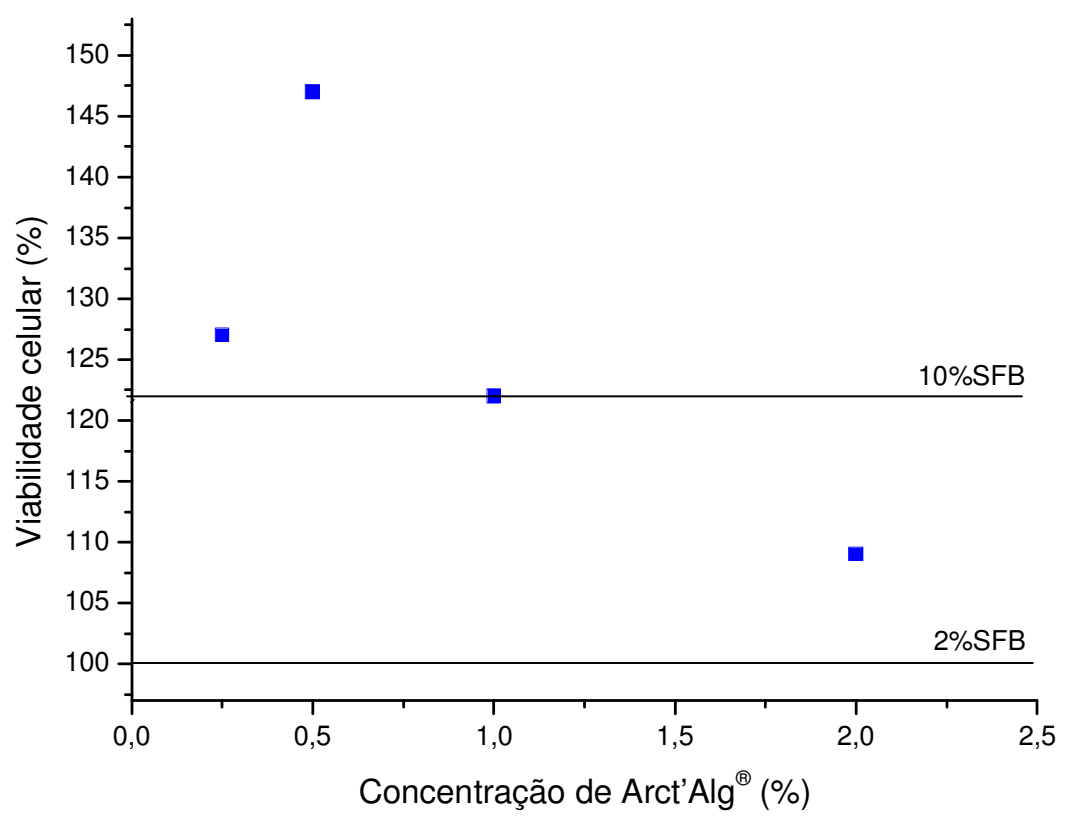

FIGURA 45. Viabilidade celular em função da concentração de $\operatorname{Arct'}^{\prime} \operatorname{Alg}^{\circledR}$ com incubação da microplaca por 48 horas - ensaio 1. 
TABELA 20. Resultado da viabilidade celular em função da concentração de Arct'Alg ${ }^{\circledR}$ com incubação da microplaca por 48 horas - ensaio 2.

\begin{tabular}{cc}
\hline CONCENTRAÇÃO DE & VIABILIDADE CELULAR (\%) \\
SFB (\%) em MEM + L-15 & \\
\hline 10 & $104 \pm 12$ \\
2 & $100 \pm 15$ \\
\hline \hline CONCENTRAÇÃO DE ARCT'ALG \\
$(\%)$ & \\
\hline 0,25 & $109 \pm 10$ \\
0,5 & $105 \pm 12$ \\
1 & $102 \pm 14$ \\
2 & $98 \pm 12$ \\
\hline
\end{tabular}

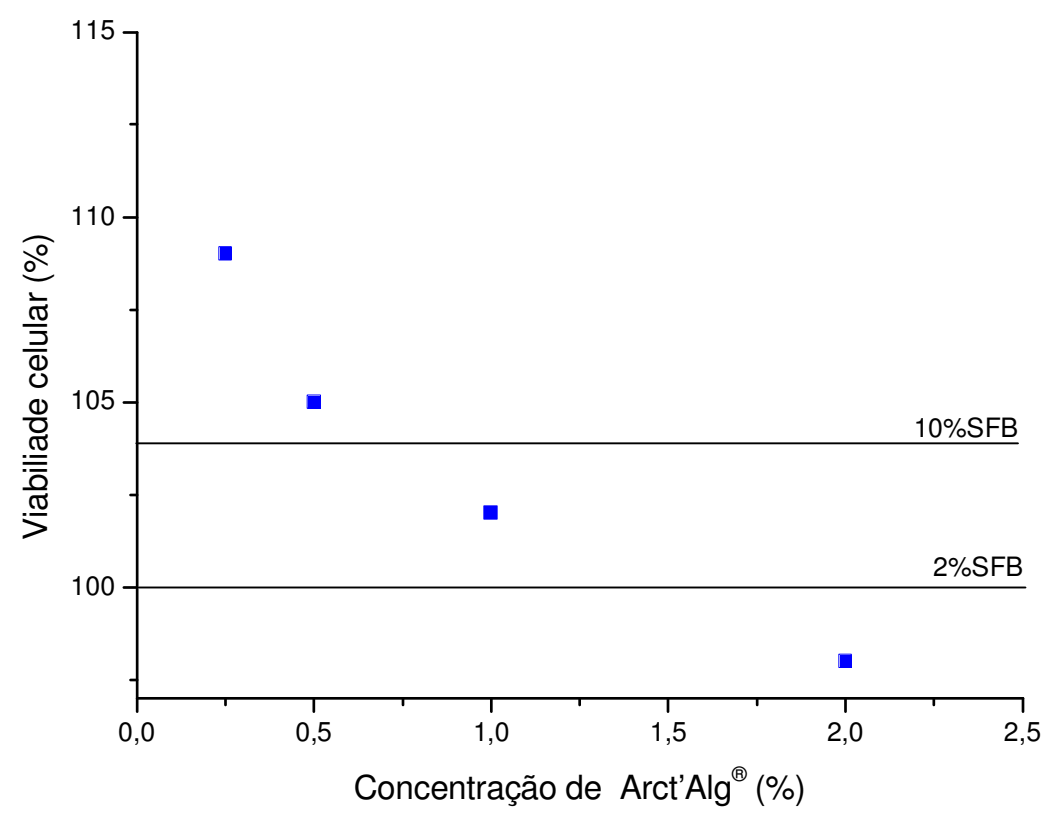

FIGURA 46. Viabilidade celular em função da concentração de $\operatorname{Arct}^{\prime} A{ }^{\circledR}{ }^{\circledR} \mathrm{com}$ incubação da microplaca por 48 horas - ensaio 2. 


\section{REFERÊNCIAS BIBLIOGRÁFICAS}

1 AJJI, Z.; OTHMAN, I.; ROSIAK, J.M. Production of hydrogel wound dressings using gamma radiation. Nucl. Instrum. Methods Phys. Res., v. 229, p. 375380, 2005. Section B.

2 AMERICAN SOCIETY FOR TESTING AND MATERIALS - ASTM D 882-95: Standard test method for tensile properties of thin plastic sheeting, 1995.

3 AMERICAN SOCIETY FOR TESTING AND MATERIALS - ASTM D 570: Test method of test for water absorption of plastics, 1998.

4 AMERICAN SOCIETY FOR TESTING AND MATERIALS - ASTM D 2765: Standard test methods for determination of gel content and swell ratio of crosslinked ethylene plastics, 1995.

5 BARABAS, E.S. N-vinyl amide polymers. In: MARK; BIKALES; OVERBERGER; MENGES. Encyclopedia of polymers science and engineering. New York, N.Y.: Wilei - Interscience, v.17, p. 167-198, 1989.

6 BARDÓCZ, S., DUGUID, T.J., BROWN, D.S., GRANT, G. PUSZTAL, A., WHITE, A., RALPH, A. The importance of dietary polyamines in cell regeneration and growth. Br. J. Nutr., v.73, p. 819-828, 1995.

7 BARRY, B.W. Structure, function, diseases and topical treatment of human skin. In: BARRY, B.W. Dermatological formulations: percutaneous absorption. New York: Marcel Dekker, p. 1-48, 1983.

8 BAUMANN, L. WEISBERG, E. Cosmetic dermatology: principles and practice. New York, N.Y.: McGraw-Hill, 2002.

9 BONINA, P.; PETROVA, T.; MANOLOVA, N. pH-sensitive hydrogels composed of chitosan and polyacrylamide - preparation and properties. $\mathbf{J}$. Bioact. Compat. Polym., v.19, p. 101-116, 2004.

10 BRADLEY, R. Radiation Technology Handbook. New York, N.Y.: Marcel Dekker, 1984. 
11 BRIDSON, E.Y. The Oxoid Manual, 9 ed., 2006.

12 BURCZAK, K.; FUJISATO, T.; HATADA, M.; IKADA, Y. Protein Permeation trough poly(vinyl alcohol) hydrogel membranes. Biomaterials, v.15, n. 3, p. 231-238, 1994.

13 CAREY, F.A.; SUNDBERG, R.J. Advanced organic chemistry. New York, N.Y.: Plenum Press, 1983.

14 CARVALHO, R.A., GROSSO, C.R.F. Effect of thermal and enzymatic treatment on the properties of gelatin films. Ciênc. Tecnol. Aliment., v. 26, n.3, p. 495-501, 2006.

15 CHARLESBY, A. Atomic radiation and polymers. London: Pergamon Press, 1960.

16 CHIEN, Y.W. Advances in transdermal systemic medication. In: CHIEN, Y.W. (Ed.) Transdermal controlled systemic medications. New York, N.Y.: Marcel Dekker, p. 1-22, 1987.

17 CIAPETTI, G,; GRANCHI, D.; VERRI, E.; SAVARINO, L.; CAVEDAGNA, D.; PIZZOFERRATO, A. Application of a combination of neutral red and amido black staining for rapid, reliable cytotoxicity testing of biomaterials.

Biomaterials, v.17, p. 1259-1264, 1996.

18 CHRISTOPHE, P. N-Acetyl-L-citrullyl-L-arginine: The dipeptide who came in from the cold. Fragr. J., v. 34, n. 3, p. 69-73, 2006.

19 CLEGG, D.W.; COLLYER, A.A. Irradiation effects on polymers. New York, N.Y.: Wiley Interscience, 1964.

20 CLINTON, N.; MATLOCK, P. Poly(ethylene glycol)s. In: MARK; BIKALES; OVERBERGER; MENGES. Concise encyclopedia of polymers science and engineering. New York, N.Y.: Wilei - Interscience, p. 338-339, 1990.

21 CLOUGH, R.L.; SHALABY, S.W. Radiation Effects on Polymers. Washington: American Chemical Society, 1991.

22 COTRAN, R,S.; KUMAR, V.; COLLINS, T. ROBBINS - Patologia estrutural e functional. 6. ed. Rio de Janeiro: Guanabara Koogan, 2000. 
23 DUSSE, L. M. S.; VIEIRA, L. M.; CARVALHO M. G. Revisão sobre óxido nítrico. J. Brás. Patol. Med. Lab., v. 39, n. 4, p. 343 - 350, 2003.

24 EISENBRAND, G.; POOL-ZOBEL, B.; BAKER, V.; BALLS, M.; BLAAUBOER, B.J.; BOOBIS, A.; CARERE, A.; KEVEKORDES, S.; LHUGUENOT, J-C.; PIETERS, R.; KLEINER, J. Methods of in vitro toxicology. Food Chem. Toxicol., v.40, p. 193-236, 2002.

25 EXSYMOL Arct'Alg ${ }^{\circledR}$ Technical documentation , 2005.

26 FARHATAZIZ; RODGERS, M.A.J. Radiation chemistry: principles and applications. New York, N.Y.: VCH Publishers, 1987.

27 FARMACOPÉIA BRASILEIRA. 3ed. São Paulo:Andrei Editora, 1977.

28 FINTER, N.B. Dye uptake methods for assessing viral cytopathogenicity and their application to interferon assays. J. Gen. Virol., v. 5, p. 419-427, 1969.

29 FLORY, P.J. Principles of Polymer Chemistry. NewYork, N.Y.: Cornell University Press, 1986.

30 FRANK, S., KAMPFER, H., WETZLER, C., PFEILSCHIFTER, J. Nitric oxide drives skin repair: novel functions of an established mediator. Kidney Int., v.61, p. 882-888, 2002.

31 GEHRKE, S.H., LEE, P.I. Hydrogels for drug delivery systems. In: TYLE, P. (Ed.) Specialized Drug Delivery Systems. New York, N.Y.: Marcel Dekker, v. 41, p. 333-392, 1990.

32 GIMÉNEZ, J.V.G., GONZÁLES, J.A., ALBANDEA, N. Tratamiento del envejecimiento cutâneo mediante bioestimulación com factores de crecimiento autógenos. Int. J. Cosm. Med. Surg., v.7, n.2, p. 8-14, 2005.

33 GUIRRO, E.; GUIRRO, R. Fisioterapia Dermato-Funcional. 3. ed. Barueri: Manole, 2002.

34 HELLER, J. Drug Delivery Systems. In: RATNER, B. D.; HOFFMAN, A. S.; SCHOEN, F. J.; LEMONS, J. E. (Ed) Biomaterials Science: an introduction to materials in medicine. San Diego: Academic Press, p.346-356, 1996.

35 ISO document 10993-1, Biological evaluation of medical devices, Part 1, Evaluation and testing, 2003. 
36 ISO document 10993-1, Biological evaluation of medical devices, Part 5, Tests for cytotoxicity: in vitro methods, 1992.

37 JONES, I.; CURRIE, L.; MARTíN, R.A. A guide to biological skin substitutes. Br. J. Plast. Surg., v.55, p. 185-193, 2002.

38 JUNQUEIRA, L.C., CARNEIRO, J. Histologia Básica. 11. ed., Rio de Janeiro: Gauanabara Koogan, 2008.

39 KALAK, P., KRAUSOVÁ, P. A review of dietary polyamines: formation, implications for growth and health and occurrence in foods. Food Chem., v.90, p. 219-130, 2005.

40 KIM, S.W., BAE, Y.H., OKANO, T. Hydrogels: swelling, drug loadind, and release. Pharmaceut. Res., v.9, n.3, p.283-290, 1992.

41 KUDELA, V. Hydrogels. In: MARK; BIKALES; OVERBERGER; MENGES. Concise encyclopedia of polymers science and engineering. New York, NY: Wilei - Interscience, p. 458-459,1990.

42 KURISAWA, M.; YUI, N. Dual-stimuli-responsive drug release from interpenetrating polymer network-structured hydrogel of gelatine and dextran. J. Control. Release, v.54, p.191-200, 1998.

43 LANGER, R., PEPPAS, N.A. Advances in biomaterials, drug delivery, and bionanotechnology. AIChE J., v.49, n.12, p. 2990-3006, 2003.

44 LEHNINGER, A.L., NELSON, D.L., COX, M.M. Princípios de bioquímica. 2.ed, São Paulo: Sarvier, 1995.

45 LEONARDI, G.R.; MATHEUS, L.G.M. Penetração cutânea. Em: LEONARDI, G.R. Cosmetologia aplicada. São Paulo: Santa Isabel, 2.ed, 2008.

46 LIMA, A.S., GLÓRIA, M.B.A. Aminas bioativas em alimentos. Bol. Soc Bras. Ciênc. Tecnol. Alim., v.33, n.1, p. 70-79, 1999.

47 MACDERMOTT, C. P. Selecting thermoplastics for engineering applications. New York, N.Y.:Marcel Dekker, 1984.

48 MARTEN, F.L. Vinyl alcohol Polymers In: MARK; BIKALES; OVERBERGER; MENGES. Encyclopedia of polymers science and engineering. New York, NY: Wilei - Interscience, v.17, p. 19-42, 1989. 
49 NIELSEN, L. Mechanical Properties of Polymers and Composites. New York, N.Y.: Marcel Dekker, p.1-17, 1998.

50 O'DONNELL, J.H. Chemistry of radiation degradation of polymers. In: CLOUGH, R.L.; SHALABY, S.W. (Ed.) Radiation Effects on Polymers. Washington: American Chemical Society, p. 402-413, 1991.

51 PEPPAS, N. A. Hydrogels. In: RATNER, B. D.; HOFFMAN, A. S.; SCHOEN, F. J.; LEMONS, J. E. (Ed.) Biomaterials Science: an introduction to materials in medicine. San Diego: Academic Press, p.60-64, 1996.

52 PEPPAS, N.A.; BURES, P.; LEOBANDUNG, W.; ICHIKAWA, H. Hydrogels in pharmaceutical formulations. Eur. J. Pharm. Biopharm., v. 50, p.27-46, 2000.

53 PEPPAS, NA.; HUANG, Y.; TORRES-LUGO, M.; WARD, J.H.; ZHANG, J. Physicochemical foundations and structural design of hydrogels in medicine and biology. Annu. Rev. Biomed. Eng. 2, p. 9-29, 2000.

54 QIU, Y.; PARK, K. Environment-sensitive hidrogels for drug delivery. Adv. Drug Del.. v.53, p.321-339, 2001.

55 RATNER, B.D. Biomaterials Science: an interdisciplinary endeavor. In: RATNER, B. D.; HOFFMAN, A. S.; SCHOEN, F. J.; LEMONS, J. E. (Ed.) Biomaterials Science: an introduction to materials in medicine. San Diego: Academic Press, p.1-8, 1996.

56 RAZZAK, M.T.; DARWIS, D.; ZAINUDDIN, SUKIRNO. Irradiation of polyvinyl alcohol and polyvinyl pyrrolidone blended hydrogel for wound dressing. Rad. Phys. Chem., 62, p. 107-113, 2001.

57 REICHMANIS, E.; O'DONNELL, J.H. The effects of radiation on hightechnology polymers. Washington: American Chemical Society, 1989.

58 RIBEIRO, C. Cosmetologia aplicada e dermoestética. São Paulo: Pharmabooks, 2006.

59 RODAS, A.C.D.; OHNUKI, T.; MATHOR, M.B.; LUGÃO, A.B. Irradiated PVAI membrane swelled with chitosan solution as dermal equivalent. Nucl. Instrum. Methods Phys. Res., v. 236, p. 536-539, 2005. Section B.

60 ROGERO, S.O., MALMONGE, S. M., LUGÃO, A.B., IKEDA, T.I., MIYAMARU, L., CRUZ, A.S. Biocompatibility study of polymeric biomaterials. Artif. Organs, v. 27, n. 5 , p. 424-427, 2003. 
61 ROSIAK, J.; RUCINSKA-RYBUS A.; PEKALA W. (1989) Method of Manufacturing of Hydrogel Dressings. Patent U.S.A. No. 4, 871,490.

62 ROSIAK, J.M.; ULANSKI, P.; PAJEWSKI, L.A., YOSHII, F., MAKUUCHI, K. Radiation formation of hydrogels for biomedical purposes. Some remarks and comments. Rad. Phys. Chem. 46, 161-168, 1995.

63 ROSIAK, J.M. Hydrogel Dressings. In: CLOUGH, R.C; SHALAB, S.W. Radiation Effects on Polymers. Whashington: American Chemical Society, 1991.

64 ROSIAK, J.M.; ULANSKI, P. Synthesis of hydrogel by irradiation of polymers in aqueous solution. Rad. Phys. Chem. V.55, p. 139-151, 1999.

65 ROSIAK, J.M.; OLEJNICZAK, J. Medical Applications of radiation formed hydrogels. Rad. Phys. Chem. V.42, n 4-6, p.903-906, 1993.

66 SCHNABEL, W. Polymer degradation, principles and practical applications. Munich: Hanser International, 1981.

67 SEM, M., GUVEN, O. Radiation synthesis of poly(N-vinyl-2-pyrrolidone/itaconic acid) hydrogels and their controlled release behaviours. Rad. Phys. Chem., v.55, p.113-120, 1999.

68 SEN, M.; AGUS, O.; SAFRANY, A. Controlling of pore size and distribution of PDMAEMA hydrogels prepared by gamma rays. Rad. Phys. Chem. v.76, p. 1342-1346, 2007.

69 SOUSA, M.A.J.; VARGAS, T.J.S. Anatomia, fisiologia e função da pele. Em: KEDE, M.P.V.; SABATOVICH, O. Dermatologia estética. São Paulo: Atheneu, 2004.

70 SPINKS, J.W.T.; WOODS, R.J. An introduction to radiation chemistry. 3.ed. New York, N.Y.: John Wiley \& Sons, 1990.

71 UHRICH, K.E., LANGER, R., CANNIZZARO, S.M., SHAKESHEFF, K.M. Polymeric systems for controlled drug release. Chem. Rev., v. 99, p. 31813198, 1999.

72 ULRICH, H. Introduction to industrial polymers. New York, N.Y.: Hanser Publishers, 1982.

73 VALENTA, C.; AUNER, B.G. The use of polymers for dermal and transdermal delivery. Eur. J. Pharm. Biopharm., v.58, p. 279-289, 2004. 
74 VISSER, S.A.; HERGENROTHER, R.W.; COOPER, S.L. Polymers. In: RATNER, B. D.; HOFFMAN, A. S.; SCHOEN, F. J.; LEMONS, J. E. (Ed.) Biomaterials Science: an introduction to materials in medicine. San Diego: Academic Press, p.50-60, 1996.

75 WITTE, M.B., BARBUL, A., SCHICK, M.A., VOGT, N. BECKER, H.D. Upregulation of Arginase Expression in wound-derived fibroblasts. J. Surg. Res., v.105, p. 35-42, 2002.

76 WILLIAMS, D.F. Definitions in biomaterials. In: Progress in Biomedical Enginering. March 3-5, 1986, Chester, England. Proceedings of a Concensus Conference of the European Society for Biomaterials.

77 YOSHII, F.; ZAINUDDIN, S.A. Heat stability of radiation crosslinked poly(vinyl alcohol) hydrogel. Rad. Phis. Chem., v. 46, 2, p. 169-174, 1995.

78 YOSHII, F.; ZHANSHAN, Y.; ISOBE, K.; SHINOZAKI, K.; MAKUUCHI, K. Electron beam crosslinked PEO and PEO/PVA hydrogels for wound dressing. Rad. Phis. Chem., v. 55, p. 133-138, 1999.

79 ZHANG, K.; WU, X. Y. Temperature and pH-responsive Polymeric Composite Membranes for Controlled Delivery of Proteins and Peptides. Biomaterials, v.25, p. 5281-5291, 2004.

80 ZHAO, L., MITOMO, H., ZHAI, M., YOSHII, F., NAGASAWA, N., KUME, T. Synthesis antibacterial PVA/CM-chitosan blend hydrogel with electron beam irradiation. Carboh. Polym., v. 53, p. 439-446, 2003. 